LUÍS HENRIQUE DO AMARAL E SILVA

\title{
Ficção e trauma em Paul Auster
}

(Versão original)

Tese apresentada ao Instituto de Psicologia da Universidade de São Paulo para obtenção do título de Doutor em Psicologia

Área de concentração: Psicologia Experimental

Orientador: Prof. Dr. Luís Cláudio Mendonça

Figueiredo

São Paulo 
SILVA, L. H. A. Ficção e trauma em Paul Auster. Tese apresentada ao Instituto de Psicologia da Universidade de São Paulo para obtenção do título de Doutor em Psicologia (Área de concentração: Psicologia Experimental).

Aprovado em:

Banca Examinadora

Prof. Dr. Instituição:

Julgamento: Assinatura:

Prof. Dr. Instituição:

Julgamento: Assinatura:

Prof. Dr. Instituição:

Julgamento: Assinatura:

Prof. Dr. Instituição: Julgamento: Assinatura:

Prof. Dr. Instituição:

Julgamento: Assinatura: 
Para Patrícia, com profundo amor, carinho e gratidão por me acompanhar pelos labirintos. 


\section{AGRADECIMENTOS}

Ao CNPq, por permitir e financiar essa pesquisa, e aos funcionários do PSE..

Com meu profundo respeito e admiração, ao meu orientador e querido prof. Luís Cláudio Figueiredo, pela paciência, imensa generosidade no compartilhamento de seu vastíssimo repertório e disposição de aceitar essa empreitada. Essa tese também é fruto do incentivo à liberdade de pensamento que sempre encontrei nas suas orientações.

A todos os professores que aceitaram fazer parte da banca e que tiveram uma importância expressiva na minha formação e no que há de sensibilidade em mim: professora Ana Maria Loffredo, querida amiga e minha primeira mentora e condutora pelos caminhos freudianos; professor Nelson Coelho Jr., em quem sempre encontrei a expressão encarnada do acolhimento ético e com quem iniciei minhas primeiras leituras na fenomenologia a partir de suas aulas; professora Inês Loureiro, de quem sou admirador e que tive a felicidade e a honra de compartilhar geladas e terapêuticas cervejas após os grupos de orientação; professora e escritora Noemi Jaffe, que tive o imenso prazer de conhecer num fala sobre seu belíssimo livro, que ajudou a inspirar alguns dos sonhos cegos dessa tese.

A minha esposa, Patrícia, por tudo e mais um pouco.

Aos meus pais, Carlos Celso e Cecília, pelo amor, paciência e sustentação.

Aos meus irmãos, Carlos Eduardo e Márcia, por todo apoio e esperança.

A Flávia, minha outra “irmã”, por sempre apostar em mim.

As minhas amadas sobrinhas Ana Luísa, Fernanda e Sofia, que compõem minha santíssima trindade da alegria.

A família da minha esposa, Patrícia, pela torcida e paciência.

Aos meus primos, Fabiana e Luciano: laços de infância.

A minha tia Cidinha, e ao meu tio Fábio (em memória).

Aos meus padrinhos de casório e irmãos de cerveja: André, Bruno, Danilo e Fabiano. Obrigado por aguentar minhas neuroses acadêmicas..

Aos meus amados amigos: Guilherme, Kate, Cláudia, Érico, Mirella, Padilha, Naty.

Aos colegas de grupo de orientação, cada um presente num momento do caminhar.

A Luciana Pires, pelos acompanhamentos no café e pelo apoio fundamental.

A Alexandre Maduenho, um dos mentores no meu caminhar clínico.

A Emir Tomazelli, que sempre ajudou a olhar outras imagens nas poças de Pinóquio.

A Silvio, Sandrinha e Wesley cujas gotas de sabedoria e carinho foram fundamentais e curativas. 
"Sacode-o 'um impetuoso vento norte', balança-o, a garganta tem espasmos, a marionete invoca uma última vez aquele que não existe, o pai.”

Giorgio Manganelli - Pinóquio: um livro paralelo

“... sempre se perde perdão quando se escreve.” Jacques Derrida - Circonfissão 


\section{RESUMO}

SILVA, L. H. A. Ficção e trauma em Paul Auster. 2014. 131 p. Tese (Doutorado) - Instituto de Psicologia, Universidade de São Paulo, São Paulo, 2014.

O presente trabalho busca explorar como a dimensão do traumático incide na literatura contemporânea, mais especificamente, na literatura de um escritor nova-iorquino, Paul Auster. Supomos que as modalidades de subjetivação de determinado período histórico podem ser investigadas a partir de objetos estéticos culturais particulares, ou, pelo menos, que determinadas obras podem servir como uma espécie de testemunho e de historiografia dos sofrimentos de uma época. Esboçamos possíveis ressonâncias entre o plano geral da cultura e da história e o das qualidades específicas e expressivas de uma obra determinada, o que abre espaço para um diálogo entre esses domínios. Com isso, contudo, não se espera privilegiar o que é externo à obra em detrimento dela, e muito menos explicar a literatura pelo recurso a teorias e sistemas de compreensão prévios. Ao contrário, partimos de uma leitura próxima e imanente às obras para realizar ensaios a partir de três livros de Paul Auster: A invenção da solidão, O livro das ilusões e Noite do oráculo. Tais leituras seguiram uma espécie de ética da hospitalidade enquanto ética da leitura. Seguindo de perto as obras, e instalando-se nelas como num regime de habitação, fomos abrindo pontos de contato e comunicação entre as obras, bem como com outras dimensões da história, principalmente no que concerne a aspectos traumáticos e catastróficos. Os ensaios aventam a hipótese de que os livros de Paul Auster escolhidos demonstram, em seu aspecto mais formal, aspectos importantes do que veio a ser conhecido, na psicanálise, como compulsão à repetição. Além disso, a transmissão de aspectos indigestos e traumáticos transgeracionais, por via de criptas psíquicas, pode ser observada na própria autobiografia de Paul Auster, notadamente, A Invenção da solidão. As vicissitudes e destinos do trauma - em sua dimensão transgeracional e individual - são articuladas com o plano da cultura e com outros pensadores. Propomos, também, uma modalidade de leitura reparadora, em contraposição a uma leitura paranoica, para responder à complexidade e às ambiguidades das obras selecionadas.

Palavras-chave: literatura; psicanálise; autores norte-americanos; trauma; ficção. 


\begin{abstract}
SILVA, L. H. A. Fiction and trauma in Paul Auster. 2014. 131 p. Thesis (Doctorate) Instituto de Psicologia, Universidade de São Paulo, São Paulo, 2014.

The present thesis aims to explore how the dimension of the traumatic concurs in contemporary literature, particularly in the one by New Yorker writer Paul Auster. It is supposed that the forms of subjectivity in a certain historical period can be searched into on the basis of particular cultural aesthetic objects. Or, at least, certain pieces of work can render as some sort of witness, as well as historiography of suffering in a particular era. It has been possible to outline some resonances between the general cultural and historical level ground and the one of expressive and specific qualities in a certain work, which opens space for a dialog between these domains. Nevertheless it is not expected neither to grant a privilege to what is external to the piece of work to its detriment, nor to explain literature from the theories and systems of previous comprehension. To the contrary, a close and immanent reading has been made, in order to make an assay, out of three of Paul Auster's books: The invention of solitude, The book of illusions and Oracle Night. Such reading has followed some kind of hospitality ethics whereas reading ethics. Accompanying closely these works, and settling down on them as in a habitation regime, points of communication were opened between them, as well as with other dimensions of history, mainly to what concerns traumatic and catastrophic aspects. The assays suggest the hypothesis that these chosen Auster's books demonstrate, in their formal aspect, important features of what has become known in Psychoanalysis as compulsion of repeating. Furthermore, the transmission of transgenerational indigestive and traumatic aspects, through psychic crypts, can be observed in Auster's autobiography The invention of solitude. The vicissitudes and destinies of trauma - on its transgenerational and individual dimensions - are articulated with the cultural level ground and with other authors. It is also proposed a modality of repairing reading, in opposition to a paranoid reading, to respond to the complexity and ambiguity of the selected works.
\end{abstract}

Key words: literature, psychoanalysis, North American writers, trauma, fiction 
SUMÁRIO

Apresentação

A escrita de uma ausência

Retrato de um homem em ruínas

A escrita da cripta

Do desastre às constelações

100

Considerações finais

123

REFERÊNCIAS

127 


\section{Apresentação}

Tentarei, nessa breve apresentação, fazer um apanhado e uma contextualização, ainda que sucinta, do que me levou a escolher um escritor contemporâneo nova-iorquino, Paul Auster, para se elaborar questões referentes à literatura, à psicanálise e ao contemporâneo. Em seguida, apontarei alguns fios a serem perseguidos na redação dos próximos capítulos da tese.

O percurso realizado até aqui, que culmina nessa tese, aos moldes de uma experiência não programada contemplou, em alguma medida, uma espécie de luto (ou lutos). Em primeiro lugar, o luto de certa abordagem, por demais reducionista, para se pensar e se entrar em contato com uma obra de arte. Tal abordagem, calcada em esquemas de leitura e interpretação prévios e exteriores à experiência com a obra, funcionariam como uma espécie de parapeito conceitual explicativo que, além de proporcionar certa “proteção” alérgica, também arriscaria sufocar a obra dentro de seus contornos rígidos, numa espécie de esquematismo transcendental a priori. Ainda que, no limite, talvez seja impossível travar um encontro com uma obra de arte (no caso, um texto) sem alguma espécie de teoria, ou teorização (mínima que seja e no sentido mais amplo do termo), o risco da teoria (psicanalítica, sociológica ou o que for) açambarcar a obra, numa espécie de fagocitose interpretativa, parece sempre estar à espreita. O risco da redução da obra de arte à função de explicação ou ilustração de teorias externas à obra é que tal redução quase sempre estaria a serviço das teorias, e muito pouco das obras.

Sem mais me estender nesse luto, outras considerações se fazem necessárias, contudo, para contextualizar de onde inicialmente parti.

Antes de mais nada, por que Paul Auster? E por que o traumático como elemento a ele endereçado ou aproximado?

Minhas inquietações e interesses ao iniciar o doutorado surgiram a partir de uma série de questões inter-relacionadas, advindas da clínica psicanalítica, de algumas interpretações de certo mal-estar difuso contemporâneo e de alguns diagnósticos críticos acerca desse mesmo contemporâneo. Poderíamos elencar várias dessas leituras diagnósticas, em diferentes campos do conhecimento. A partir da psicanálise, por exemplo, Figueiredo (2003) nomeou o que ele entenderia como uma espécie de cultura do traumático, marcada, entre outras coisas, pelo excesso de estímulo, competição e violência, mas sem a contrapartida da oferta de objetos confiáveis e disponíveis (inclusive institucionais) capazes de realizar toda espécie de mediação e continência dessas desproporções, intensidades e excessos, do que resultaria uma 
espécie de traumatização crônica. No campo da sociologia, o nome de Zygmunt Bauman, entre outros, se fazia notar, para mim, com sua leitura do contemporâneo marcado pela liquefação de todos os sólidos (instituições, valores, emprego etc.). Mundo líquido que vive sob o signo da transitoriedade, velocidade, incerteza, precariedade e insegurança, atacando, desde seus fundamentos, tudo o que ancoraria o ser humano em sua existência. Fraturas do ethos humano, desencaixe (Giddens, 1999), intensificação ou embotamento dos afetos (Jameson, 1991)... e a lista torna-se tão disseminada e talvez até fragmentada como os discursos, as práticas e a estética dita “pós-moderna”.

O traumático prolifera em inúmeras formas e modalidades, mais ou menos visíveis, e até a sua repetição exaustiva e saturada pelos meios de comunicação acrescenta mais camadas de violência ao que já é por si só difícil de assimilar (basta assistir a quinze minutos de um telejornal sensacionalista para se intoxicar com o excesso grotesco e a aglomeração de elementos muito pouco simbolizáveis e demasiadamente violentos).

Se o século XX chegou a ser denominado como a era das catástrofes, as condições que permitiram a proliferação desses sofrimentos inauditos não parece ter se extinguido em nosso século XXI, o que não deixaria de dar razão aos imperativos categóricos (aos moldes daqueles de Kant) formulados por Adorno. Meu interesse, contudo, seria pensar as modalidades de subjetivação possíveis advindas desse contexto contemporâneo, possivelmente marcado pelo traumático. Para tanto, a escolha de uma obra de arte poderia ser uma boa via de entrada para investigar essas reverberações subjetivas do contemporâneo. Em grande medida, minha aposta aqui não deixa de se aproximar das formulações de Adorno (Cf. Zamora, 2004) acerca da possibilidade de se pensar que algumas obras de arte também poderiam funcionar como uma modalidade de historiografia inconsciente do sofrimento do seu tempo.

Dessa forma, minha investigação caminharia no sentido de tentar compreender a arte como (possível) modalidade de testemunho do sofrimento de sua época. Evidentemente, a noção de testemunho terá que ser problematizada e nuançada. De fato, a literatura de testemunho tem uma história particular e sua emergência, a partir da Shoah, tem características e problematizações próprias, como muito bem demonstra Seligmann-Silva (2005). A noção de testemunho, além disso, adquire diferentes usos e conotações em seus diferentes campos (jurídico, literário, psicanalítico etc.), muito embora isso não exclua o fato da relação, tensão e mesmo contaminação entre eles. Por exemplo, para Derrida (Blanchot; Derrida, 2000), a noção jurídica de testemunho - enquanto atestação - sempre seria assombrada pela possibilidade do perjúrio e, portanto, da mentira e mesmo da ficção. 
Paul Auster me pareceu, a princípio (o que depois, evidentemente, veio a ser muito mais complexificado), ser um interessante autor representante de nossa época, principalmente no que se refere à vida em grandes metrópoles, à relação com a tradição, ao papel do escritor e mesmo quanto às respostas da arte frente ao traumático ${ }^{1}$.

Inicialmente, esse traumático surgiu para mim logo na minha primeira experiência de leitura de Auster, a partir do seu livro Trilogia de Nova York. Como efeitos dessa leitura, posso citar: as sensações de enclausuramento, vertigem, desorientação, a angústia decorrente dos finais abertos, do absurdo das situações, a tontura frente à disseminação e dispersão das identidades dos personagens etc. O enclausuramento, além disso, ressurgia e era intensificado também com as sucessivas leituras de sua obra, como um efeito da repetição de imagens com as quais eu já estava familiarizado. De fato, ao se ler os diferentes livros de Paul Auster, temos a impressão de estarmos relendo o mesmo livro, mas contado de outra maneira, com outros personagens, ou talvez com os mesmos, mas recontextualizados ou mesmo descontextualizados. Ao final, ficamos mesmo na dúvida se Paul Auster não está recontando a história da sua vida, em diferentes versões, sempre ficcionalizando um pouco mais a si mesmo, ou se está apenas acrescentando mais personagens a uma estória que, ainda que desde sempre aí, jamais teve começo. Ou então, ficamos com a sensação de que Auster nos prega peças e que mesmo sua aparição "literal” em uma de suas estórias não deixa de ser um ato jocoso para com o leitor, como se fosse a realidade que invadisse a ficção para torná-la absurda.

O próprio Auster - e ainda não sabemos se brincando ou não - reforça a ideia de que seus livros poderiam ser uma espécie de um incessante comentário de outros livros, tanto os seus mesmos quanto os de outros autores que ele leu e que fizeram parte de sua formação, entre eles, Beckett, Celan, Mallarmé, Kafka, Hawthorne, Jabès. Numa entrevista concedida que chegou a ser incluída no livro que também reúne seus principais ensaios, $A$ arte da fome, Auster (1992) chegara a dizer que as três estórias que compõem a Trilogia de Nova York seriam na verdade três versões da uma mesma estória (só não sabemos qual seria!), três volteios ao redor de um centro enigmático, de uma história original que se esconde por detrás das suas outras versões.

\footnotetext{
${ }^{1}$ Se fôssemos fazer uma espécie de pequeno (e incompleto) inventário de alguns temas que circulam e insistem na obra de Auster, na lista encontraríamos: o artista como pária, a incidência do traumático e dos eventos inesperados como modeladores da identidade, a relação entre ficção e realidade, o fracasso da linguagem para nomear e para religar palavras e coisas (a "queda” da linguagem), a ruína dos mitos fundadores da cultura americana, a solidão, o estar na multidão das grandes metrópoles, a escrita como forma de luto, o escritor e a tradição, a aleatoriedade dos eventos da vida, a tentativa de se abraçar o sem-sentido como modalidade existencial, o misticismo sem Deus e, para ficarmos apenas aí, o livro como (impossível) morada e exílio.
} 
Livros que são o comentário de outros livros, e cujos finais enigmáticos ensejam novas escrituras. Aqui, podemos perceber claramente a influência de uma de suas referências e autores prediletos: Edmond Jabès. Em entrevista concedida a Auster, Jabès diferenciava sua ideia do Livro daquela de Mallarmé (que queria, segundo Jabès, colocar todo conhecimento num livro, fazer "um grande livro”, “o livro dos livros”): “O livro que teria a chance de sobreviver, eu penso, é o livro que destrói a si mesmo. Que se destrói em favor de outro livro que o prolongará”. (citado em Auster, 1992, p. 152). Entre ambos os autores, Auster e Jabès, percorre a tradição de leitura midráshica. Todavia, a presença do judaísmo em Auster não comparece como um tema explícito sobre o qual ele discorrerá. Antes, o judaísmo aparece mais como espectro, como sombra. Nunca nomeado diretamente, a herança e a questão judaica em Auster parece se fazer notar, antes, pelas referências aos escritores judeus com quem ele se identifica, mas também por uma espécie de demanda de reelaboração silenciosa de um passado doloroso. Auster parece herdar, querendo ou não, uma imensa tarefa de reelaboração do sofrimento de seus antepassados (e de seu próprio). De fato, a conjunção do “naufrágio do singular” com o sofrimento dos demais permite alguma ligação entre os traumas, numa modalidade de compartilhamento da dor. Desse compartilhamento, que ele próprio adquire feições de uma alteridade traumática (há um endereçamento vindo sabe-se lá de onde), pode emergir a possibilidade de alguma outra coisa, talvez da própria (re)abertura da historização, ao contrário de uma eterna repetição de um tempo congelado.

Assim, se nosso interesse se deu em adotar Auster como um representante do sofrimento do seu tempo (do nosso ainda), numa espécie de ligação horizontal, o passado, esse eixo vertical, e aqui também transgeracional, ainda assim invadirá e ajudará a tornar o campo mais denso e problemático, numa espécie de policronia.

Como tentaremos elaborar ao longo da tese, a (re)escritura do trauma, parece, é o que possibilitará, em alguma medida, e sempre de maneira parcial e precária, a saída do confinamento em que o escritor se encontra (o mesmo valendo para muitos de seus personagens que também são escritores), quase num estado de estase e congelamento. O livro, em Auster, representa, entre outras coisas, esse lugar de confluência entre um passado talvez não assimilável e a necessidade imperiosa de reelaboração e luto. Lugar de exílio, de recolhimento e de memória, todavia ele também é uma morada difícil, talvez um cárcere. Os impasses e as oscilações entre aprisionamento e libertação, entre perlaboração e repetição traumática parecem nunca cessar, garantindo um equilíbrio para sempre instável.

Auster, todavia, também problematiza toda a noção de origem. Mesmo os fatos colecionados e narrados em seus livros de cunho mais autobiográfico parecem ser 
assombrados sempre pela ficcionalização. Como será visto no primeiro ensaio dessa tese, o uso de fotos que poderiam comportar uma espécie de origem que localizaria (e, presumivelmente, também apaziguaria) o sujeito acaba por denunciar, ao contrário, já a fratura e a instabilidade dessa origem supostamente recuperada. Fotomontagem, fotos rasgadas e depois coladas, álbuns dispersos e nunca de fato reunidos... tais imagens nos sugerem que, na origem (aqui, no caso, a sua origem familiar), está a fratura, mas também a dispersão, a ficção, o rastro de outros rastros, a loucura, o silêncio ruidoso... O que lhe parecia um solo confiável sobre o qual se apoiar - a origem "real” de sua família - traz as marcas da ficção e, talvez, da mentira.

Se um passado deve ser (re)acessado, no entanto ele só o pode ser indiretamente, o que sempre denunciará seu caráter mediado, reconfigurado, numa palavra, reescrito. E o livro é o médium desse acesso: “O passado, entretanto, não pode ser diretamente percebido: ele apenas pode ser experienciado através dos livros.” (Auster, 1992, p. 45). Se a noção e crise da referência estão o tempo todo presente em seus livros, isso não implica que o referente deixe de existir. Não se trata, portanto, de um abandono do passado, da realidade ou da História. Trata-se, antes, da problematização de um acesso puro e direto à verdade dos fatos.

Assim, a problematização das fronteiras e da relação entre ficção e realidade também percorre e quase que emoldura a obra de Auster. O escritor nova-iorquino afirmava querer escrever uma ficção tão estranha e extraordinária quanto a realidade que ele via todo dia, esta última também composta por fatos misteriosos e fantásticos, acasos e coincidências inacreditáveis, pequenos milagres do cotidiano. A realidade - para ele tão estranha quanta a ficção é capaz de ser - parece ser atravessada por fios invisíveis que religam experiências distantes no tempo e no espaço, fazendo cruzar destinos, pessoas, histórias etc. Sem adotar uma instância ou entidade transcendente por detrás disso, Auster resvala numa espécie de misticismo sem Deus, ou mesmo retoma a suposta relação (embora sem harmonia) da mônada leibniziana com o todo. No entanto, esse mesmo Deus - ainda que misterioso e incognoscível - volta pelas portas dos fundos, não sob a voz de Auster, mas sim pela de seus “outros”, seus duplos, entre eles, novamente, Edmond Jabès. O poeta egípcio, ainda em sua entrevista, delineia uma relação com essa alteridade radical cuja estrutura em muito se assemelha com a relação de Auster com seu próprio pai:

Não tenho medo da palavra "Deus" porque não tenho medo desse Deus... O que quero dizer por Deus em minha obra é algo com que nos defrontamos, um abismo, um vácuo, algo em relação ao qual somos impotentes. É uma distância... a distância que existe sempre entre as coisas... Nós chegamos onde queremos e, então, existe ainda essa distância por cobrir. Chega o 
momento em que você não mais consegue cobrir a distância; você chega lá e diz para si mesmo: acabou, não há mais palavras. Deus talvez seja uma palavra sem palavras. Uma palavra sem significado. (citado em Auster, 1992, p.149).

A estranheza dessa realidade, e no caso, dessa realidade última (“a distância que existe entre as coisas”) denota uma opacidade irredutível, mas que força uma busca, por vezes desesperada, para atravessar esse deserto. Em Auster, apesar de não ser uma busca pelo Deus das religiões, há essa espécie de condição existencial precária do caminhar num deserto, rumo a alguma Terra Prometida. No entanto, essa busca é assumida com certa coragem, embora sempre assombrada pelo risco do engano e dos descaminhos, e mesmo da loucura. É curioso notar que Auster selecionou e organizou uma coletânea de estórias de ouvintes de um programa de rádio, cujo título veio a ser “Achei que meu pai fosse Deus”. Seria importante, em alguma medida, explorar como esse seu misticismo secular articular-se-ia com a busca pelo pai, esse grande ausente que impregna sua vida e obra. Além disso, pelas palavras de Jabès, mas palavras que invadem o texto de Auster, muitas questões vinculadas à questão judaica reaparecem, e mesmo os mortos parecem não querer se calar, embora toda escrita seja submetida a uma enlouquecedora hesitação entre o poder dizer e a impossibilidade de dizê-lo, carregando uma culpa e uma dívida que nunca parece ser quitada, que está sempre, portanto, em perjúrio.

Essa culpa da arte traz um peso por vezes insustentável aos processos de reelaboração e reparação do passado por meio dessa atividade. A reconciliação nunca é garantida. Todavia, ainda assim algo move os personagens (e o próprio Auster?) a continuar arriscando ir ao encalço de vozes espectrais. O que ele escreveu sobre Jabès, agora num ensaio sobre a obra do poeta egípcio, vale também para seus textos:

Se a linguagem deve ser levada até seu extremo, então o escritor deve se condenar a um exílio de dúvida, a um deserto de incerteza. O que temos de fazer, com efeito, é criar uma poética da ausência. Os mortos não podem ser ressuscitados. Mas eles podem ser ouvidos, e suas vozes vivem no Livro. (Auster, 1992, p.105).

Auster tentar ouvir essas vozes em seus livros, embora tais sons, muitas vezes não articulados, só possam ser entreouvidos a partir de vestígios e rastros. Nunca são vozes plenamente presentes. São ecos, murmúrios.

Em Auster, a escrita (mas a arte em geral também) está em constante embate e tensa relação com as feridas e catástrofes que assolam a vida, seja no plano individual, seja no coletivo. Tão logo materializada, a arte estaria em risco e em vias de destruição. É nesse 
meio-fio que a arte e os personagens de Auster vivem, como se cada palavra proferida tivesse que ser apagada, e aí também estaria algo de seu testemunho. Quando não são as palavras (afinal, os livros de Auster chegam até os leitores; os relatos, de alguma forma, vingam e chegam a algum destinatário), são os personagens que são apagados, dos quais, por vezes, só restam rastros.

Em nossa tese, queremos também fazer pequenas alusões acerca das modalidades desse traumático então. Não fizemos isso antes do confronto com os textos para não recairmos nos mesmos procedimentos protocolares que enquadram o texto com a autoridade de quem já sabe o que irá encontrar neles (mas esse risco não está afastado de nós em nenhum momento...).

Todavia, algo já se prenuncia. Sem entrarmos na leitura detida dos textos ainda, é recorrente em Auster o traumático enquanto catástrofe, o que engendra diversas reações de defesa ao choque traumático “externo” (também precisaríamos problematizar essa noção de externo). Estamos em plena herança freudiana das reações de defesa frente ao choque traumático, com suas metáforas das barreiras de proteção que são rompidas. Ademais, também é evidente que, para além dessa dimensão quase econômica do trauma, há a necessária teorização acerca de sua dimensão no plano dos sentidos, sendo o traumático aquilo que resiste à simbolização, numa clara filiação freudo-lacaniana, ou mesmo, na tradição fenomenológica, a filiação levinasiana. Com o decorrer das leituras, essas incidências traumáticas vão se alargando e ganhando espaço, o que torna difícil estabelecer e diferenciar as diversas modalidades do traumático.

As diversas imagens no texto de Auster acerca também da queda nos instigam a pensar nessa condição de um equilíbrio frágil e suspenso que se rompe. De fato, muitos personagens de Auster trazem essa marca de uma queda catastrófica já ocorrida. São sujeitos, ou melhor, sobreviventes de algum desastre, de algum rompimento (famílias desfeitas, doenças, imobilidade psíquica, morte, perda da identidade, entre outros signos). Somado ao luto de perdas irreparáveis, há a perda ou a fratura do solo de confiança primordial sobre o qual se assenta a vida psíquica.

Para além da possível loucura gerada pela indeterminação entre o que é real e o que é ficção, e mesmo do encarceramento dentro dessa fronteira incerta, Auster parece nos sugerir que, diante de uma situação traumática que desconfigura a realidade, fazendo romper suas coordenadas mais básicas (esse abalo do solo de confiança primordial, ou mesmo seu estilhaçamento radical), talvez a necessidade da ficção (com seu risco suplementar de ampliar o labirinto) seja ainda mais imperiosa, como se a ficção fosse convocada para reconfigurar a 
realidade destroçada e a confiança perdida. Nessa linha, nos depararemos também com a ideia de que, diante de alguns eventos tão perturbadores, algo de verdadeiro sobre o que aconteceu só pode ser transmitido através da ficção (e "através”, aqui, adquire o sentido mesmo de atravessamento), como se na ficção pudesse haver a possibilidade de alguma verdade se insinuar.

Além disso, a ficção e, principalmente, a autobiografia ficcional (deixamos em suspenso, contudo, a denominação do gênero empregado por Auster em $A$ invenção da solidão, dado o caráter instável não somente dessa modalidade literária quanto do uso que Auster faz dela), dão margem à possibilidade da literatura reconstituir não só uma pelenarcísica para o autor (e leitor) ${ }^{2}$ como também de redimir e dar voz aos mortos, talvez lhes permitindo - mortos e vivos - chorar pela primeira vez. Os trabalhos de luto e reparação, portanto, podem ser levados a cabo com a ajuda da ficção (independentemente do status de verdade e historicidade de seus referentes, personagens etc.).

A tese aqui em tela tentará seguir algumas dessas pegadas, tentando elaborar a relação ou a economia possível entre ficção e traumatismo.

Algumas palavras precisam ser ditas também sobre a "escolha” do procedimento de leitura realizado, a saber, algo que se aproxima do ensaio. A palavra veio entre aspas porque tal escolha nunca existiu, mas como que foi exigida à medida que minha pesquisa foi se desenvolvendo. Nisso, pelo menos, a forma ensaio emergiu a partir da experiência de leitura. Após alguns desses exercícios de leitura, fui me deparando, nas reuniões de orientação, com a ideia de que a forma ensaio foi se delineando como uma via de aproximação da obra literária de Auster. O ensaio mereceu meditações interessantíssimas de diversos autores, entre eles Adorno e Starobisnki, e não iremos nos deter nisso nesse momento, embora posteriormente esse problema também voltará a ser abordado. Há, é claro, uma investigação que precisa ser feita sobre a questão da forma adequada para transmitir determinados conteúdos.

Por outro lado, o ensaio sempre questionou a noção de método, sendo talvez avesso à herança do pensamento sistemático e dedutivo, ou pelo menos, sua sistematicidade seria outra.

O ensaio suspende ao mesmo tempo o conceito tradicional de método. O pensamento é profundo por se aprofundar em seu objeto, e não pela profundidade com que é capaz de reduzi-lo a uma outra coisa. O ensaio lida com esse critério de maneira polêmica, manejando assuntos que, segunda as regras do jogo, seriam considerados dedutíveis, mas sem buscar a dedução definitiva. Ele unifica livremente pelo pensamento o que se encontra unido

\footnotetext{
${ }^{2}$ Embora isso não seja necessário nem constitua sua principal potência ou objetivo.
} 
nos objetos de sua livre escolha. Não insiste caprichosamente em alcançar algo para além das meditações - e estas são mediações históricas, nas quais está sedimentada a sociedade como um todo -, mas busca o teor de verdade como algo histórico por si mesmo. (Adorno, 2003[1974], p. 27).

O ensaio tem um caráter aberto, alérgico à arquitetura dos sistemas fechados. Poderíamos trazer aqui outra ideia ainda, uma que o filósofo brasileiro Haddock-Lobo (2011) desenvolveu sobre o "úmido", esse conceito indeterminado, a meio caminho entre o molhado e o seco, um híbrido e um monstro para o pensamento calcado em categorias binárias claras e distintas. Algo semelhante ao que Merleau-Ponty pensara acerca da carne, o úmido desfaz as categorias bem delimitadas e reasseguradoras. O título de seu livro reflete a orientação tomada por Haddock-Lobo: Por um pensamento úmido. Aqui, tomando emprestada essa noção e nos inspirando nela, em alguma medida nosso "método" (que desestabiliza a noção de método) estaria mais próximo dessa umidificação. Talvez, além disso, em certas passagens mais secas e desalentadoras, a umidade poderia ter servido como algum bálsamo.

A tese conta com três ensaios e mais uma capítulo que realiza uma leitura cruzada uma espécie de metaleitura - do que até então terá sido produzido.

O primeiro ensaio acompanha a primeira obra em prosa do escritor, $A$ invenção da solidão, uma autobiografia ficcional que surge em resposta à morte súbita do pai, empreendendo um trabalho de luto por intermédio das ruínas que restam desse pai.

O segundo ensaio, já totalmente no plano da ficção, realiza uma leitura detida de $O$ livro das ilusões, cuja trama se desdobra ao redor de um homem que perdera a família num desastre de avião. Buscando elaborar o luto dessa perda, o personagem encontra na obra e na história de um antigo ator de cinema mudo a possibilidade da escrita.

O terceiro ensaio mergulha na obra Noite do oráculo, que retrata os impasses e dificuldades de um personagem às voltas com o seu próprio desaparecimento subjetivo, após um tempo internado num hospital. Aqui, a perda é de si mesmo, a criação de estórias o auxiliará nessa aventura.

Com o quarto capítulo, é trabalhado um entrecruzamento das três leituras, descortinando aspectos e dimensões das obras que os ensaios já vinham anunciando, principalmente no que tange à complexidade da situação traumática. 


\section{A escrita de uma ausência}

Já faz quase um ano que ele tira fotografias de coisas abandonadas. No mínimo, tem duas tarefas a cumprir todos os dias, às vezes elas chegam a seis ou sete, e, toda vez que ele e seu séquito entram numa casa, confrontamse com as coisas, as inumeráveis coisas rejeitadas, deixadas para trás pelas famílias que se foram. As pessoas ausentes partiram às pressas, todas elas, envergonhadas, confusas, e é certo que, onde quer que estejam morando agora (caso tenham encontrado um lugar para morar e não estejam acampadas no meio da rua), suas novas moradias são menores do que as casas que perderam. Cada casa é uma história de fracasso - de falência ou de inadimplência, de dívida e de execução de hipoteca - e ele assumiu a missão de documentar os últimos vestígios daquelas vidas desfeitas a fim de provar que as famílias desaparecidas estiveram ali algum dia, que os fantasmas de pessoas que ele nunca vai ver e jamais irá conhecer ainda estão presentes nas coisas descartadas, dispersas em suas casas vazias. (Auster, 2012, p. 7).

Eis o primeiro parágrafo de um dos últimos livros lançado no Brasil de Paul Auster, Sunset Park, cuja trama se desenrola em plena crise americana das hipotecas, que, tal qual o Katrina, acabou por deixar, após enxurrada e vendaval, terras, casas e famílias devastadas. Essa referência à crise imobiliária norte-americana - ou aos rastros de sua passagem - denota que os "fatos" e acontecimentos da história comparecem, em alguma medida, como personagens nos livros de Paul Auster. Pode-se elencar uma série deles, que dão as caras abertamente, e muitos deles de ordem traumática ou catastrófica: num plano mais geral e coletivo (com todo o risco de generalização e imprecaução que se corre aqui), a perseguição e assassinato dos judeus na Shoah, a resistência e levante do Gueto de Varsóvia contra o exército alemão, o sofrimento da guerra no Camboja, o terrorismo e as ações virulentas dos EUA em resposta etc.; numa esfera mais individual, o sofrimento e sonhos de Anne Frank, o grito silencioso embutido nas pinturas do quarto de Van Gogh, a loucura e encarceramento de Hölderlin num quarto etc.

Iremos problematizar, mais à frente, ainda que de maneira tangencial, o estatuto da referência na literatura - aqui, nesse caso específico, a referencialidade histórica, ou mesmo autobiográfica, como comparece reiteradamente em Paul Auster. Como se tornou lugarcomum em uma certa (e talvez limitada) leitura da obra atordoante de Derrida, julgou-se que a referência fora decretada extinta e abandonada de vez na dita virada pós-estruturalista. A referência, ou poderíamos dizer, de forma aproximada, a "realidade”, faria sua volta, irônica e vingativa, ao se chutar as canelas dos “desconstrucionistas”, quando estes acreditavam, piamente, na máxima de que não havia o "fora-texto”. Essa crítica caricata meio que diria: "ah 
é? Então tome isso! Agora diga que não existe o fora-texto!”. Tratando-se de uma leitura limitada (embora possamos concordar que Derrida nunca é tão transparente e de fácil entendimento), não levava em conta que afirmar que não existe uma instância transcendental que controla - de fora - o texto (ou o sentido do texto), não implica, todavia, em dizer que o texto, conforme afirma $\mathrm{Natali}^{3}$, não faça referência ou remeta a algo para além dele, que não busque seu Outro, e que também não seja afetado e impactado por todo contexto de criação e recepção de uma obra, nem muito menos que algo como a "realidade” não exista. Seja como for, na verdade a relação “dentro-fora” em Derrida é palco de grandes tensões, reversões e instabilidades que não nos cabe percorrer aqui.

No caso da literatura, no entanto, dessa estranha instituição chamada literatura, como diria Derrida, isso ficaria ainda mais pronunciado. A literatura, mesmo sem conter em si nenhuma essência que a defina a priori, ainda assim “é”, talvez desde sempre e paradoxalmente (já que ela questiona inclusive a linguagem da essência), uma rede de relações, quase um sistema de reenvios, para usar o jargão heideggeriano, apontando para algo sempre além do texto.

Mas voltemos ao texto de Auster...

Essa imagem de espaços vazios, com rastros de uma vida que já não está mais lá, de ruínas de subjetividades para sempre perdidas, poderia servir como uma entrada para quase todos os livros de Auster, o que poderia, aparentemente, e mais uma vez numa leitura apressada e preconceituosa, dar razão a James Wood quando este afirma que a obra de Auster é recheada de repetições, clichês e joguinhos pós-modernos superficiais. Esse famoso crítico literário norte-americano e professor de Harvard, assumidamente avesso e alérgico a quase todas as produções literárias que ele intitula de "pós-modernismo", afirma, entre outros ataques contra Auster, que, neste, o vazio é sempre muito dizível.

Tomaremos certa distância dessa crítica agressiva de Wood, que chega a ser mais condescendente e piedoso em relação a outros escritores contemporâneos a Auster, como Don DeLillo, por exemplo. Vale apenas ressaltar que a própria crítica de Wood, pelo menos tal como ele a apresenta no jornal New Yorker, também pode ser rapidamente ignorada pela rapidez e pouca atenção que dedica ao próprio texto de Auster, numa espécie de bravata também enfadonha. A leitura atenta e próxima, que ele dedica a vários clássicos de literatura, mas também a não tão clássicos assim, como John Updike (embora também aqui não seja tão

\footnotetext{
${ }^{3}$ Em aula ministrada na FFLCH-USP, na disciplina “Do Sofrimento: questões de literatura e ética” do Programa de Teoria Literária e Literatura Comparada. (primeiro semestre de 2012).
} 
elogiosa), não parece ocorrer com relação a Auster, pelo menos não em sua crítica divulgada no jornal acima mencionado.

Seja como for, de fato há uma ou várias obsessões e repetições a assombrar Auster. Os espaços vazios, o quarto onde o escritor, em sua solidão, percorre o mundo por intermédio da memória e da imaginação, a busca pelos desaparecidos, a aleatoriedade dos eventos da vida, a estranha "rima" que esses mesmos eventos adquirem quando colocados lado a lado, o livro como refúgio e/ou cárcere, a escrita como meio de lidar e elaborar o traumático etc. Essa insistência, que dá ensejo, é verdade, a sentirmos que estamos lendo novamente a mesma história $^{4}$, mas com personagens diferentes, não nos parece o fracasso do escritor novaiorquino em se reinventar. Antes, nos parece que há um atravessamento dessas imagens e temas na obra de Auster, muitas vezes numa modalidade que se assemelha aos mecanismos de compulsão à repetição com que as “cenas” traumáticas reaparecem em sonhos, ou mesmo em atuações. Reencenando e percorrendo essas imagens, numa espécie de paráfrase de sua própria obra, os personagens de Auster estão às voltas com a tarefa de terem de fazer o luto de diversas ausências e aspirações, bem como elaborar (ou perlaborar) cenas e situações traumáticas.

Retornando ao parágrafo que lançamos no início, ele pode ser, então, descontextualizado e recontextualizado ad infinitum. Ora, então recuemos de sua suposta historicidade no momento - no caso em questão, a crise socioeconômica que se abateu nos EUA -, embora sem abandoná-la por todo, para podermos usar, provisoriamente, essa imagem como moldura para outras cenas de Paul Auster. Ou então aceitemos a ideia de que, talvez, não saibamos a que Auster se refere. Aceitemos esse fragmento disperso e arremessado no nosso texto e brinquemos com ele.

O que nos sugere essa moldura?...

Aqui, ela nos serve de antessala para adentrarmos em outra câmara.

Em Auster, há sempre uma busca de pessoas e histórias desaparecidas.

\footnotetext{
${ }^{4} \mathrm{O}$ próprio Auster alude a essa imagem de que seus livros seriam o comentário insistente sobre uma mesma história ou evento. Porém, ao mencionar esse evento, a própria redação da segunda parte de $A$ invenção da solidão, somos lançados numa paradoxal situação. Como veremos, esse segundo capítulo, intitulado "O livro da memória”, trata da meditação de uma multidão de temas e imagens, ainda que correlatas, além de poder ser lido como uma espécie de autobiografia intelectual. A questão crucial é que esse evento não tem o caráter de uma origem absoluta, já que, lá, somos remetidos e arremessados para diversas direções simultaneamente (a fatos da vida de Auster, à biografia de diversos autores etc.) o que, numa clara proximidade com o pensamento da desconstrução, problematiza a ideia de uma origem única e plenamente identificável de qualquer texto. Assim, se obras posteriores de Auster remetem e aludem a essa obra inaugural, quando para lá "voltamos" ficamos desnorteados ao sermos lançados para novas "origens”, novos comentários de comentários, numa cadeia aberta.
} 
Um dos primeiros personagens desaparecidos de Auster, um personagem estranhamente bem real e irreal ao mesmo tempo, foi seu pai.

A invenção da solidão foi escrito logo após a morte de seu pai, em plena crise conjugal e financeira de Auster, e num momento de transição de sua produção artística, quando começava a se sentir mais livre e autorizado para escrever em prosa.

Tão inesperado quanto os acontecimentos traumáticos que irrompem em suas estórias, a morte do pai o lançou num tortuoso processo de luto, levado a cabo (ou assim se presume) com o auxílio da escrita.

Já o título dessa primeira parte do livro, “Retrato de um homem invisível”, nos anuncia o tema e os impasses que Auster enfrentaria. Estamos no campo do visível invisível. O relato da busca e tentativa de reconstituição da história de seu pai - ou, como veremos, daquilo que era avesso à reconstituição - é marcado por uma voz narrativa em primeira pessoa, numa espécie de relato (auto)biográfico. Auster conta a história de seu pai e vai, durante a confecção do texto, afundando em camadas e mais camadas de mistérios e passagens da vida de ambos.

A ideia de escrever sobre ele lhe surgiu num relance, quase como uma necessidade ou um comando imperioso: "Pensei: meu pai se foi. Se eu não agir depressa, sua vida inteira vai desaparecer junto com ele.” (Auster, 1982, p. 12).

Ao contrário de suas expectativas, a morte em si do pai, pelo menos no princípio, não lhe gerou o entorpecimento que ele previa teoricamente quando se pensa a morte de um ente familiar tão próximo. De início sem lágrimas, sem tristeza, o que lhe afligia era o fato de que seu pai não deixaria vestígios. Não tinha mais esposa, sem amigos, sem alguém que dependesse dele, ninguém teria sua vida alterada com sua ausência (o que, veremos, não seria bem assim). Mas não só isso...

Marcado por uma ausência em vida, como se já tivesse ido embora há muito tempo antes, antes mesmo de sua morte "real”, Auster descreve seu pai como alguém...

Destituído de paixão por uma coisa, por uma pessoa ou por uma ideia, incapaz ou sem ânimo de se revelar em nenhuma circunstância, ele conseguiu se manter longe da vida, evitar a imersão no âmago das coisas. Comia, ia para o trabalho, tinha amigos, jogava tênis e no entanto, em tudo isso, não estava presente. No sentido mais profundo, mais inalterável, meu pai era um homem invisível. Invisível para os outros e, muito provavelmente, invisível para si mesmo. Se, enquanto estava vivo, eu andava sempre em busca dele, sempre tentando encontrar o pai que não estava presente, agora que ele está morto, ainda tenho a sensação de que devo continuar à sua procura. A morte não mudou nada. A única diferença é que meu tempo se esgotou. (Auster, 1982, p. 13). 
Durante os quinze últimos anos de sua vida, já separado e sem viver com os dois filhos, Sam Auster continuou a viver na casa que abrigara a família. Todavia, antes uma construção majestosa, espaçosa e imponente, a casa tornara-se, depois, descuidada e paulatinamente abandonada a si mesma. Sem renovar ou retirar nenhum móvel, a casa internamente fora ganhando ares envelhecidos e carregados de uma história (e de um sofrimento) imobilizada. Porém, como Auster afirma,

não é que ele estivesse se agarrando ao passado, tentando preservar a casa como um museu. Ao contrário, parecia não ter noção do que estava fazendo. Era a negligência que o governava, não a memória, e embora ele continuasse a morar na casa durante todos aqueles anos, vivia ali como um estranho o faria. (Auster, 1982., p. 15).

Sam Auster, em sua invisibilidade em vida, quase como um fantasma, atravessava as paredes e não se detinha nos detalhes que o cercavam. Dono de hábitos rotineiros, Sam Auster sempre voltava do trabalho à noite e tirava um cochilo antes do jantar. Quando se mudaram para a nova casa (esta em que ele veio a falecer), Sam Auster cometeu, nos dizeres de Paul Auster, um “engano interessante”: ao invés de voltar para a casa nova após o trabalho, dirigiuse para a antiga, lá entrou e foi se deitar na cama que já não era mais a dele. Apenas se deu conta quando a nova moradora do lugar gritou de pavor.

Com frequência ele parecia perder a concentração, esquecer onde estava, como se tivesse perdido a sensação da própria continuidade. Isso o tornava propenso a acidentes: unhas esmagadas por golpes de martelo, numerosos e pequenos acidentes de carro. Sua distração ao dirigir: o modo como às vezes isso se tornava apavorante. Sempre achei que uma batida é que ia acabar com ele. Por outro lado, sua saúde era tão boa que parecia invulnerável, imune aos males físicos que afligiam o resto de nós. Como se nada pudesse jamais tocá-lo. (Auster, 1982, p.38)

Essa desatenção, que beirava uma ignorância metódica até, claramente também era dirigida aos membros da família.

Entre as inúmeras passagens de indiferença e frieza que Auster descreve, podemos citar a reação do pai dirigida à esposa quanto ao iminente nascimento do filho: "Ridículo, disse ele, essa criança só deve nascer daqui três semanas - e saiu logo para o trabalho, deixando minha mãe sem o carro” (Auster, 1982, p. 26). Tendo passado o dia inteiro no hospital e dado à luz o futuro escritor, a mãe de Auster vê o marido chegar e fazer uma breve visita, acompanhado pela própria mãe, a avó de Paul Auster. Tão logo chegou, tão logo partiu. 
Trinta anos depois, após o nascimento do primeiro filho de Auster, Daniel, o avô dá uma rápida olhada para o neto, sobre o carrinho, e comenta com a esposa de Auster: "Um bebê lindo. Boa sorte com ele”. (Auster, 1982, p 27)

Essa pouca disponibilidade para algo mais do que comentários estereotipados e evasivos e sua incapacidade ou impossibilidade de enxergar o outro parecem ter impactado mais dolorosamente ainda a irmã de Paul Auster. Diante dos recorrentes e cada vez mais debilitantes "surtos nervosos” (como Auster denomina) da irmã, Sam Auster negava que ela pudesse precisar de terapia, conforme um psiquiatra tinha recomendado. Não que ele não a amparasse. Apenas achava que seus surtos eram uma forma de "subterfúgio da personalidade”, que bastaria “colocar a cabeça no lugar”, “arrumar um emprego”, “começar a viver no mundo real”, "superar sua timidez” etc.

Em relação à cegueira ou, antes, à falta de imaginação do pai em relação ao sofrimento da filha, Paul Auster comenta:

Em que momento uma casa deixa de ser uma casa? Quando o telhado é removido? Quando as janelas são retiradas? Quando as paredes são postas abaixo? Em que momento a casa se transforma em um monte de escombros? Ela é só diferente, dizia meu pai, não há nada de errado com ela. E então, um dia, as paredes da casa um dia desmoronam. Se a porta ainda permanece de pé, no entanto, tudo o que a gente tem a fazer é atravessá-la, e já está de novo do lado de dentro. É agradável dormir ao ar livre sob as estrelas. Não importa que chova. Não pode durar muito tempo. (Auster, 1982., p. 34).

Apesar disso, simultaneamente, Sam Auster também havia construído uma fortaleza extremamente vigiada e imune a invasões de estrangeiros. Um dos seus recursos e artifícios era criar personagens de si mesmo, muitas vezes muito caricatos, jocosos ou mesmo irresponsáveis.

\begin{abstract}
A capacidade de evasão do meu pai era quase ilimitada. Uma vez que a esfera do outro era irreal para ele, suas incursões nessa esfera eram feitas com uma parte dele mesmo que considerava igualmente irreal, uma outra pessoa que ele treinara como um ator para representá-lo na comédia vazia do mundo em geral. Essa pessoa substituta era essencialmente um gozador, uma criança hiperativa, um fabricante de conversa fiada. Não conseguia levar nada a sério. Como nada tinha importância, ele dava a si mesmo a liberdade para fazer o que bem entendesse (entrar de penetra em clube de tênis, fingir que era crítico de restaurantes para comer de graça), e a sedução que exercia para levar a cabo suas proezas era exatamente o que retirava todo o valor dessas proezas. (Auster, 1982., p. 23).
\end{abstract}

Esse tom ressentido em relação às jocosidades do pai, contudo, contém uma grande dose de verdade quando se pensa o quão difícil seria conviver com alguém que nunca 
conseguisse estar plenamente presente a um encontro humano, a não ser se representado por um dos seus personagens ou comentários hilários ou evasivos. Como claro mecanismo de proteção, essa ficcionalização doentia de si mesmo ${ }^{5}$ anunciava um fronteira invisível que nunca deveria ser atravessada por ninguém, ou que, se ameaçada de invasão, outros subterfúgios de evasão seriam acionados.

Auster escava no amontoado de objetos-detritos de seu pai espalhados pela casa após sua morte (escova de dentes, bisnaga de tintura de cabelo, roupas à espera de alguém que nunca mais as usará, preservativos nas gavetas etc.), nas camadas rapidamente em processo de fossilização, buscando resgatar do olvido cacos e fragmentos de sua passagem pela vida, mas sabendo, de antemão, do fracasso de sua busca. O desespero de se deparar com objetos cujas histórias vão se apagando no sepultamento corrosivo de um buraco negro que os engole. Ao mesmo tempo em que tais objetos remetem a uma solidão que já não está mais aí, mas que ainda assim assombra na forma de um espectro, Auster também pressente que mesmo essa camada mais superficial (e, com a morte do pai, cada vez mais evanescente) do self, composta de objetos e utensílios domésticos, de registros de um cotidiano banal, precisaria ser perfurada por sua escavadeira literária e sua memória. Como se Auster precisasse aprofundar e abrir terreno para um mergulho (uma queda?) num buraco mais fundo, rumo a uma dimensão mais mineralizada, talvez anterior a qualquer fóssil, a qualquer vestígio encobridor que sinalizasse uma pseudo-vida.

No meio do caminho, entre a superfície e as primeiras camadas subterrâneas, Auster se lembra de como gostava da maneira que seu pai assinava seu próprio nome.

Ele não conseguia simplesmente pôr a caneta no papel e escrever. Como se adiasse de forma inconsciente a hora da verdade, ele sempre fazia um breve floreio preliminar, um movimento circular a quatro ou cinco centímetros da página, como um inseto zumbindo no ar e ajustando a mira no seu alvo, antes de poder baixar e pôr a mãos à obra. (Auster, 1982., p.38)

Nessa camada no limiar do subterrâneo, Auster parece identificar uma indecisão e uma hesitação mais antigas, talvez a mesma dificuldade de habitar o presente que ele identificara em seu pai, em outras situações. Nesses microabalos sísmicos, nessa oscilação e tremor do existir que a oscilação da mão segurando a caneta desenha, e que quase passa despercebida por todos, Auster não deixa de intuir fraturas geológicas muito mais profundas e amplas.

\footnotetext{
${ }^{5}$ Ora, mas não poderíamos também aí encontrar, mesmo que a contragosto de Paul Auster, um certo fascínio que essa dramaturgia de si mesmo poderia ter exercido sobre ele?
} 
Ainda nesse caminho de perfuração, uma lembrança, agora positiva, quase como um relicário da memória perdido no meio dos escombros.

Auster se lembra de como seu pai lhe contava histórias de sua vida antes do casamento. Sam Auster contava do tempo que trabalhou em prospecção mineral na América do Sul e outras aventuras insólitas. O que encantava o filho era a maneira "elegante" e "rebuscada” com o que pai as contava. Uma das primeiras apreciações estéticas, narrativas e, talvez, literárias de Paul Auster.

À cata de objetos que narrassem um personagem, ou ao menos algo de sua atmosfera, Auster encontra um antigo álbum de família no armário do pai (nesse recinto ainda mais recôndito e talvez interditável). Não é sem culpa ou mal-estar que Auster perscruta o ambiente físico e os objetos pessoais do pai. Afinal, alguém que se esforçou tanto para se esconder, por que deveria, então, ser devassado por um comitê da Verdade? A culpa pela escrita, associada a um ato infrator, violador ou mesmo profanador, aparece com toda força aqui. Não estaríamos muito longe, por exemplo, da culpa sentida por Derrida (1991) ao continuar a escrever após a morte de sua mãe, e a continuar a escrever um texto que poderia, além disso, ser literário. A culpabilidade da escrita, mesmo sua cumplicidade com o sofrimento, não deixa de estar em questão aqui, algo que também assombrou Lévinas em seus primeiros textos, ou mesmo Adorno.

Talvez uma série de questões surja aqui. Todo o vocabulário acerca do que paira sobre a leitura e sobre a literatura, tais como as expressões "fidelidade ao texto", do "texto como algo sagrado” etc. traz consigo, embutida, uma herança teológica deveras marcante, numa linhagem que Derrida estende até suas raízes abraâmicas ${ }^{6}$. A dessacralização do mundo operada pela modernidade não impediu que houvesse uma ressacralização, entre outras coisas, da e na arte. Esse sagrado, sempre passível de profanação (a traição do tradutor, por exemplo, é tanto sua condição de possibilidade e de impossibilidade), também remeteria às imagens e questões levantadas pelo sacrifício, ou mesmo por uma responsabilidade ética. Se a literatura é a instância onde tudo pode ser dito, haveria limites a ela? Quais os limites de sua liberdade? O que ela poderia (e também não deveria) eventualmente sacrificar? O que o leitor poderia (e também não poderia) sacrificar em sua leitura? Lévinas, por exemplo, temeria o risco de idolatria da arte, bem como a confusão entre o Absoluto e sua representação, de forma a ocasionar um fechamento da arte em torno dela mesma. Quando a arte consola, ela se evadiria da “realidade”, ou antes, do que seria o seu Outro? Ao mesmo tempo, contudo, o próprio

\footnotetext{
${ }^{6}$ Cf. Derrida (1999), Dar la muerte.
} 
Lévinas, como também Adorno, verá em algumas obras o verdadeiro testemunho de um sofrimento que muitas vezes não pode ser encarado de frente.

Nesse livro, Auster está às voltas com uma aparente tentativa de reconstituição de seu pai, mas, também, e simultaneamente, de reconstituição de si mesmo. Anterior a qualquer tentativa de reparação (embora isso não esteja excluído), na linha de pensamento da psicanalista Melanie Klein, parece-nos que Auster enfrenta os impasses da escrita como tentativa de um (auto) retrato. Um certo caráter de (res)subjetivação está implicado aí, numa esperança imperiosa de se salvaguardar alguma pele narcísica. Estaria aí a escrita atrelada a essa função de consolo, ou mesmo de cuidados narcísicos? Mas se assim o for, qual o custo (sacrifício) disso?.

Mas voltemos aos aposentos do senhor Sam Auster antes que sejamos oferecidos num altar qualquer...

No quarto do pai, numa gaveta, Auster encontra centenas de fotografias esparramadas e, junto, o álbum, muito volumoso e com o título na capa em letras douradas "ESTA É A SUA VIDA: OS AUSTER”. Ainda que uma espécie de registro pré-histórico do pai, tais fotos, contudo, contavam a vida de um fantasma. O interessante era que as fotos não estavam coladas no álbum, mas jogadas e dispersas na gaveta, como se tal álbum e seu título representassem uma promessa nunca cumprida. Ao abrir o álbum, de fato Auster encontra páginas em branco. Uma brancura que, aos moldes dos paradoxos e dos devaneios de Bachelard, parece revestir, no entanto, um negrume muito intenso.

A narrativa não é assim linear. Auster interrompe as memórias, desvia-se, passa páginas e páginas remontando-se a outras histórias, como se precisasse contornar alguns círculos antes de chegar a um suposto centro.

Umas das intrigantes fotos que ele encontra é uma montagem, feita nos anos 40, com várias imagens superpostas de seu pai. A princípio, num primeiro lance do olhar, poderia parecer se tratar de diferentes homens, mas prontamente desmentido pelo segundo olhar. 


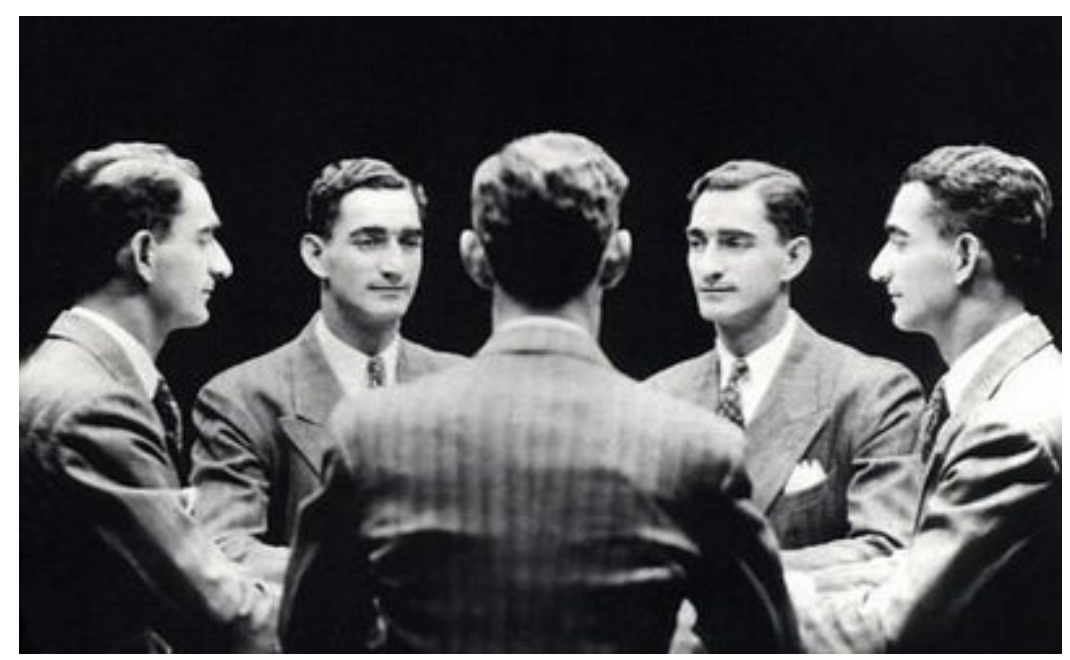

Figura 1 - Foto da capa da edição americana de A invenção da solidão.

Porém, o que a princípio parecia ser apenas uma brincadeira irônica, um breve comentário - sob a forma de imagem - de si mesmo, Auster (e nós também) apreende mais coisas...

\begin{abstract}
Em virtude das trevas que os envolvem e da completa imobilidade de suas poses, parece que se reuniram ali para promover uma sessão espírita. E então, quando examinamos melhor a fotografia, começamos a notar que todos aqueles homens são o mesmo homem. A sessão espírita se torna uma realidade e tem-se a impressão de que ele foi até lá só para invocar a si mesmo, trazer a si mesmo de volta do mundo dos mortos, como se, ao multiplicar-se ele inadvertidamente tivesse feito desaparecer a si mesmo. Há cinco imagens dele ali e no entanto a natureza do truque fotográfico rejeita a possibilidade de contato visual entre as diferentes personificações. Cada uma está condenada a olhar fixamente para o vazio, como que por baixo do olhar dos outros, mas sem ver nada, sempre incapaz de enxergar o que quer que seja. É um retrato da morte, o retrato de um homem invisível (Auster, 1982, p. 40).
\end{abstract}

Aqui, uma queda, ou um espatifar em cópias de si mesmo, não sem uma certa vertigem. Essa pulverização de personagens, de selves, ou mesmo de espectros parece ser já um anúncio, a primeira aparição dessa estrutura mise en abyme, um tropos retórico que percorrerá incessantemente toda a obra de Auster.

O morto parece brincar com os vivos. Esconde-se, recusa-se a se mostrar, mas também convida a uma aventura traiçoeira. Na ida ao encalço desse fantasma está todo o risco que Paul Auster corre, talvez um risco de se cair num buraco mais fundo junto com ele, abraçado a ele, um buraco chamado melancolia. O risco da melancolia não só espreita a todo momento A Invenção da solidão, como também a própria redação do texto tem ares melancólicos. A escrita, então, como um espaço e um tempo de elaboração, de promessa de cura ou mesmo 
redenção, mas que também comporta perigos e faz reavivar a dor e o medo por constantemente também invocar tais fantasmas.

Houve uma ferida, e agora me dou conta de que é muito profunda. Em vez de me curar, como pensei que fosse acontecer, o ato de escrever manteve essa ferida aberta. Algumas vezes, cheguei até a sentir a dor concentrada na minha mão direita, como se toda vez que eu pegava a caneta e pressionava a ponta sobre o papel minha mão estivesse sendo arrancada do braço. (Auster, 1982, p. 41).

A mão hesitante do pai que segura a caneta, a dor na mão de Auster ao manter viva a memória de seu pai... Posteriormente, na outra parte do livro, a mão de Collodi segurando a pena que mergulha no tinteiro, que reenvia a Pinóquio - esse pedaço de pau falante mergulhando na escuridão da barriga do tubarão, e que lá encontrará Gepeto... A escrita não dá garantias definitivas de cura, e sua travessia é cercada de riscos, entre eles, o risco de se cair, de ser engolido numa escura imensidão...

Em lugar de enterrar meu pai, para mim, estas palavras o mantiveram vivo, talvez mais do que nunca. Não só o vejo como era, mas como é, como será, e todo dia ele está aqui, invade meus pensamentos, me toma de assalto sem avisar: deitado no caixão sob a terra, seu corpo ainda intacto, as unhas e o cabelo continuam a crescer. A sensação de que, se quero mesmo compreender alguma coisa, preciso penetrar nessa imagem de trevas, preciso penetrar na absoluta escuridão da terra. (Auster, 1982, p. 41).

Mesmo depois de morto, o morto ainda carrega uma vida que continua a prosseguir, e que talvez não saiba que já estava morta: unhas e cabelos que continuam a crescer podem remeter a essa paradoxal condição de um copo morto ainda pulsante. Em Espectros de Marx, Derrida (1993) nos lembra dessa condição intermediária e híbrida do espectro: nem totalmente morto nem plena presença viva.

Retomando o que havíamos dito no início, não somente pequenas passagens e parágrafos introdutórios podem servir de entrada para os demais livros, como também todos os livros podem servir como o comentário infinito um do outro. Aqui, a suposta abertura do livro a recorrentes “comentários” também desenha uma clausura. ${ }^{7}$, que também não deixa de ser o risco de clausura, confinamento e limite da escrita, ou mesmo da clausura na melancolia, ou na loucura.

\footnotetext{
${ }^{7}$ Antes mesmo do que apenas uma imagem, a sensação mesma de clausura ao lermos seguidamente os livros de Auster poderia ser um dos indícios de que não só algumas figuras do traumático percorrem sua obra e seus personagens, como também esse traumático produziria, em alguma medida, tais sensações de estreitamento, aprisionamento etc.
} 
É interessante, como exemplo, nos remetermos ao livro que veio em seguida a este, e como que em resposta, A Trilogia de Nova York. Lá, na segunda estória, “Fantasmas”, a coisa se passa numa Nova York dos anos 40, mesma década de nascimento de Auster. Blue, que nunca fora detetive, é contratado por um certo White para vigiar os passos de um tal Black. Este, por sua vez, passa horas e horas no seu apartamento lendo e anotando algumas coisas. Blue, simetricamente, gasta horas do seu dia vigiando, da janela de um quarto de outro prédio em frente, essa repetida cena, em que nada acontece. Black é ainda mais nebuloso do que apenas seu nome sugeriria. É um ponto escuro na visibilidade da paisagem, com rotinas tão banais e sem nenhum indício de qualquer outra coisa por detrás de seus passos do que aquelas atividades que ele está ali fazendo. Ao final, Blue descobre que White e Black são a mesma pessoa, e que contratara Blue para vigiá-lo apenas para garantir que tivesse alguém ali fazendo isso, assegurando-o de sua existência. Blue, que redige relatórios e mais relatórios sobre esse evasivo Black, adentra no mundo da escrita como que por uma cilada. Abandona a noiva, abre mão da sua vida para apenas habitar aquele quarto em que escreve e vigia, numa vigília insone diante do nada. Parece que Black (e também Sam Auster com relação ao filho) inicia Blue na cena da escrita, na vida de certa forma interpelante e encarcerada do escritor. Da mesma forma que com os orixás, que precisam ser cultuados para não morrer, Black precisa de um olhar que o cultue, que o comente, para se manter "vivo", mesmo que como espectro, como fantasma, como um deus entre os vivos e os mortos.

Nesse momento, também nos deparamos com mais paradoxos. Como é possível testemunhar - no sentido de atestação - a passagem de alguém que nunca esteve aí? Aqui a emergência da ficção nas entranhas do testemunho ocorre não apenas por que todo testemunho é passível de perjúrio, do risco da mentira etc., como mostrara Derrida (1994). No caso em tela, a fição é, antes de tudo, também prevista e mesmo necessária para preencher a lacuna de uma fratura na própria experiência de testemunhar.

O mise en abyme também estrutura essas camadas interconectadas de ausências. Uma primeira ausência (a morte do pai que já não mais está aí) que cai para dentro de si mesma (um pai ausente em vida e que nunca esteve aí) que, por sua vez, despenca numa outra ausência ainda mais funda (o fundo sem fundo de uma alteridade para sempre inapreensível, uma condição universal de toda alteridade radical).

A confecção do livro parece seguir, segundo Auster dá a entender, pelo menos nessa primeira parte, uma abertura para acontecimentos, para descobertas.

Outra foto. Outra coincidência. 
Auster nunca soubera, de fato, como o seu avô paterno tinha morrido. As histórias que Sam Auster contava, assim como o próprio, eram múltiplas, a cada página virada um novo motivo e um novo conto para dizer o que não se podia dizer:

Na minha própria infância, ele me contou três histórias distintas sobre a morte do seu pai. Em uma versão, tinha morrido em um acidente de caça. Em outra, caíra de uma escada. Na terceira, levara um tiro na Primeira Guerra Mundial. Eu sabia que essas contradições não faziam sentido nenhum, mas supus que isso significava que nem mesmo meu pai tinha conhecimento dos fatos. Como era muito pequeno quando aconteceu - só sete anos -, imaginei que nunca lhe tivessem contado a história exata. Só que isso também não fazia sentido. Um dos irmãos sem dúvida teriam contado a verdade para ele. (Auster, 1982, p. 42).

Contudo, também os primos tinham ouvido as mesmas diferentes histórias dos pais.

Eis que Auster encontra outra foto de seus antepassados nos primeiros tempos de sua vida na cidade de Kenosha, em Wisconsin. Na foto, o pai de Auster, com não mais do que um ano, no colo de sua mãe, e os outros quatro irmãos ao lado dela. Ao fundo, a casa onde moravam e, ao redor, a grama alta e parte do tronco de uma árvore, mas um tronco aparentemente partido. A foto, claramente, tinha sido recolada e cada pedaço justaposto aos demais para re-formar a imagem. No entanto, num olhar mais detido, algo que Auster nem se deu conta no começo, nota-se que um dos irmãos se apoia em algo ou alguém que não está ali. Havia uma ausência ali, uma parte desligada e rasgada. Um tronco familiar que parece rompido...

Vi as pontas dos dedos de um homem segurando o torso de um dos meus tios; vi, de forma bem nítida, que outro de meus tios não estava apoiando a mão nas costas do irmão, como eu pensara a princípio, mas em uma cadeira que não estava ali. E depois me dei conta do que era esquisito na fotografia: meu avô fora suprimido. A imagem estava distorcida porque parte dela fora eliminada. Meu avô estivera sentado em uma cadeira ao lado da esposa com um dos filhos de pé entre seus joelhos - e ele não estava ali. Só as pontas dos dedos permaneceram: como se ele tentasse voltar sorrateiramente para a fotografia, vindo de algum profundo buraco no tempo, como se estivesse sido exilado para uma outra dimensão.

A coisa toda me fez tremer. (Auster, 1982, p. 43). 


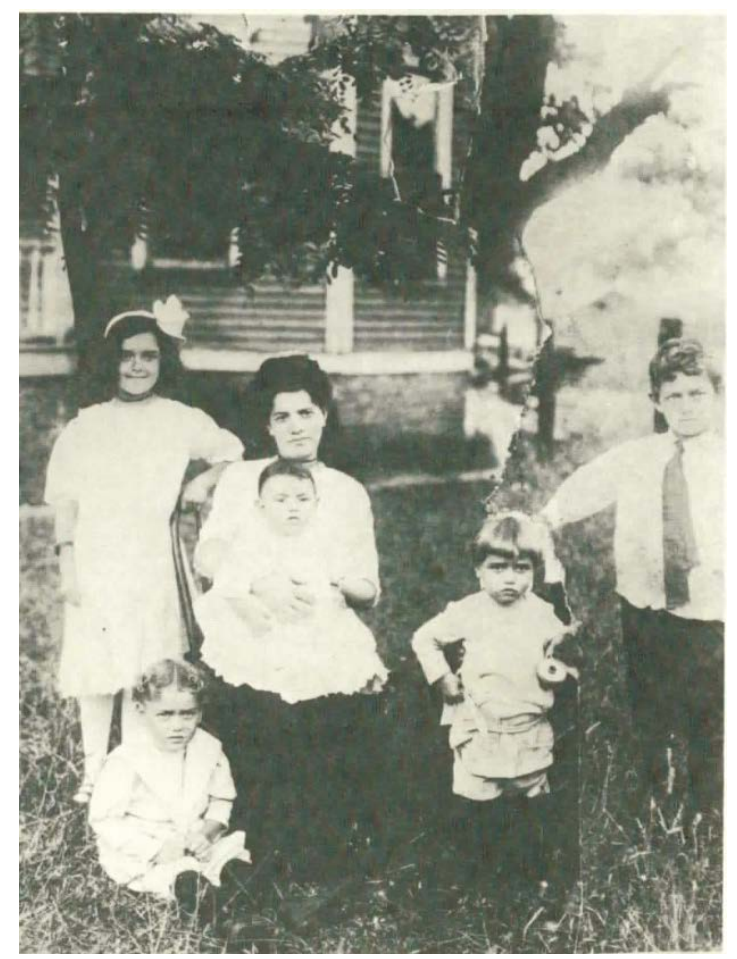

Figura 2 - Frontispício de A invenção da solidão.

O pai de Sam Auster havia sido assassinado (literal, simbólica e fotograficamente) pela mulher. A avó de Auster, num dos seus episódios enlouquecidos de ciúme (a bem da verdade, o avô aprontava lá das suas), atirara no marido, em plena cozinha, tendo como uma das testemunhas Sam Auster, ainda garoto, com sete anos. Também ela havia rasgado e remontado a foto.

Paul Auster reuniu as matérias que encontrou sobre o evento, que, à época, foi amplamente noticiado na cidade, como um caso que comprovava a loucura dos judeus: "Li as matérias como se fossem história. Mas também como desenho feito nas cavernas, descoberto nas paredes internas de meu próprio crânio”. (Ibid., p.46). Das cavernas pré-históricas mineralizadas, passamos para os primeiros registros fósseis e os primeiros desenhos nas paredes.

Um sofrimento talvez impensável esse o testemunhado pelo então pequeno Sam. Nunca falou disso com ninguém. Sabe-se que, com a absolvição da avó no julgamento (o advogado havia conquistado a sensibilidade do júri para mostrar que havia sido um crime de ciúmes passional), a família se reunira novamente, e Sam continuou a viver com a mãe, completamente devoto a ela. A matriarca, além de mãe judia e boa de mira, era de uma assertividade ímpar e também não tinha nenhum pudor em, por exemplo, invadir o quarto de Sam, quebrar e espatifar seu pequeno cofre e pegar o dinheiro que ali tinha, com a alegação 
que era para pagar as contas da casa. Sam Auster, então, passara a vida num reino do “imprevisível”, como diria Auster:

Para um menino, significava que o céu poderia desabar por cima dele a qualquer momento, que nunca poderia estar seguro de nada. Portanto, aprendeu a nunca confiar em ninguém. Nem em si mesmo. (Auster, 1982, p. $61)$.

As cenas de desabamento vão, de fato, comparecer literalmente (ou literariamente?) em vários outros livros. Entre uma dessas inúmeras cenas, por exemplo, o desabamento de uma galeria em que estava ocorrendo um concurso de dança, numa das cenas de A noite do oráculo, ou então, ainda no mesmo livro, a cabeça de gárgula que se desloca da fachada de um prédio e despenca em cima de Nick Bowen, personagem de uma história dentro de outra história (no mise en abyme, as quedas são para dentro de histórias também, uma caindo e escorregando para dentro da outra).

Porém, se nessa primeira parte de A invenção da solidão Auster está em busca de seu pai para sempre desaparecido, na segunda, intitulada “O livro da memória”, parece que Auster sai em busca de si mesmo, tomando suas memórias como pistas e vestígios.

Aqui, vale citar a epígrafe escolhida por Auster, retirada da história de Pinóquio.

'Quando os mortos choram, é porque estão começando a se recuperar', disse o Corvo em tom solene.

'Lamento ter de refutar meu amigo e colega ilustre', disse a coruja, 'mas, no que me diz respeito, creio que quando os mortos choram, significa que não querem morrer’. (Auster, 1982, p. 85).

A assombração do pai, ou então o pai como enigma, invadirá os aposentos mais recônditos de Auster. Nessa segunda parte, Auster distancia-se de si mesmo e cria um intervalo e uma lacuna, também ele ficcionalizando-se num personagem (em entrevista, ele havia dito que já não conseguia escrever em primeira pessoa para falar dessas memórias que surgiam em resposta à morte do pai). Adota a terceira pessoa do singular como voz narrativa. Nomeia-se de A. e continua a se chamar assim por todo o texto.

É um livro composto de outros treze livros, chamados livros da memória, que vão tecendo e disseminando associações e imagens, ainda que sempre de maneira elíptica, como que numa órbita aberta.

O ano da redação é 1979, em pleno período de crise do casamento, após a morte do pai, além da do avô materno. 
Nesse livro, Auster, antes de se identificar com o pai, nessa espécie de luto arriscado, sempre nas bordas da melancolia, parece incorporá-lo, ou, pelo menos, incorporá-lo como ausência, como que para circunscrevê-la. Poderíamos arriscar dizer que Auster encripta o pai.

Ao contrário do fantasma-bebê do livro Amada, de Toni Morrison (1987) ${ }^{8}$, cujo sofrimento e rancor é bastante violento e audível nos movimentos das cadeiras, das gavetas e dos armários, nos aposentos de Auster o fantasma caminha silenciosamente. Ou antes, ele marca sua ausência na austeridade do aposento. Auster, afastado da esposa e do filho, passava a semana num quarto, um prédio comercial da rua Varick, que antes fora o local de trabalho de um eletricista. Não era, portanto, um quarto para se habitar. Sua decoração era feita de canos e demais estruturas à vista na parede, com os poucos objetos e utensílios necessários a uma vida ascética (“um punhado de livros, um colchão no soalho, uma mesa, três cadeiras, um fogareiro elétrico e uma pia de água fria toda carcomida.”)...

\begin{abstract}
A despeito do que possa parecer, esta sala não é um refúgio do mundo. Aqui, nada existe que dê a ele boa acolhida, nenhuma promessa de férias para o corpo, nada que o induza ao esquecimento. Estas quatro paredes contêm apenas as marcas de sua própria inquietude e, para encontrar alguma parcela de paz nesse ambiente, ele precisa escavar cada vez mais fundo dentro de si mesmo. Mas quanto mais escavar, menos haverá para continuar escavando. Isto lhe parece inegável. Mais cedo ou mais tarde, ele está destinado a se esgotar. (Auster, 1982, p. 91).
\end{abstract}

Uma peculiar história do quarto é traçada no “Livro da memória”. Quartos como os de Van Gogh, Anne Frank, Hölderlin, Descartes, mas que se estendem a muitos outros quartos e modalidades de reclusão, cárcere, hospitalização, recolhimento, retraimento etc. O quarto de Auster na rua Varick é inóspito, esvaziado, impossível como morada. No entanto, além da comunicação silenciosa com o centro imaginário e inalcançável do pai, o quarto de Auster também serve como uma moldura aberta para a imaginação poder povoá-lo, embora, a cada saída de Auster da casa e seu posterior retorno, Auster enfrentaria a dolorosa reincorporação e conquista desse espaço. A cada volta, o recomeço de um instante, a hesitação (a mesma do pai?) de se assumir uma existência, onde a lassidão expressaria essa recusa ou o cansaço do existente em enfrentar sua existência, conforme nos ensinaria Lévinas.

Nesse intervalo, no vácuo entre o momento em que ele abre a porta e o momento em que começa a reconquistar o vazio, sua mente se debate em um

\footnotetext{
${ }^{8}$ Nesse livro, a mãe de Amada mata sua filha, ainda bebê, para que a mesma não fosse recapturada e tivesse seu destino novamente devolvido à escravatura. O que aterroriza nesse bebê é a desproporção de sua força e sofrimento - expressos nos ruídos, nos móveis que se atiram sem nenhuma causa aparente etc. - diante de pequenez de seu corpo.
} 
pânico inexprimível. É como se fosse obrigado a assistir à sua própria desaparição, como se, ao cruzar a soleira dessa sala, ele entrasse em outra dimensão, tomasse por residência um buraco negro. (Auster, 1982, p. 89).

Habitar um buraco negro, algo que a astrofísica parece não aconselhar aos viajantes intergalácticos (o despedaçamento é um risco a ser pensado), é possível, no entanto, nesses estados de extremo desespero, solidão, ou então no estado da alma em busca poética.

No entanto, também nesse devaneio uma força gravitacional parece atrair os corpos uns para os outros. A atração e queda quando um corpo menor entra no campo gravitacional de outro maior é o que Newton advertiria aos incautos aqui. Notemos que, ainda na primeira parte desse livro, Auster chegou a descrever seu pai como um "titereiro que controlava seu alter ego, a partir de um local escuro e solitário, atrás das cortinas” (Ibid., p. 23). No teatro dos bonecos controlados por fios invisíveis a graciosidade ocorre pela leveza dos movimentos, pela maneira atraente e leve com que o boneco vence a força da gravidade, dando a ilusão de ser capaz de, em sua dança fluida e solta, subir e descer ao seu bel-prazer (na verdade, segundo os desígnios de um Outro, aquele que o controla) ${ }^{9}$.

Porém, em Auster, os bonecos já se espatifaram, ou os fios invisíveis se soltaram. Eles estão sempre em queda ou em situações pós-queda (que se aproximam de situações póstraumáticas). Não por acaso, temos a recorrência de imagens de corpos que caem (mesmo o fracasso do corpo em lutar contra a gravidade e a força do tempo, no envelhecimento), quedas de objetos, dificuldades de se ficar em pé em decorrência de problemas nas pernas, ou então, ao contrário, uma queda para cima, como no personagem fantástico de Mr. Vertigo que era capaz de levitar. Podemos associar essa imagem, ainda, com Stillman Jr., filho de outro “titereiro” da linguagem, Peter Stillman (ambos personagens do conto “Cidade de Vidro”, em A Trilogia de Nova York). O filho, que fora trancafiado pelo pai num quarto escuro durante anos para que viesse a falar a língua de Deus, em seu andar desconjuntado e sem jeito assemelha-se a esse boneco de pau que aprendeu a andar pela primeira vez, depois que se livrou dos fios invisíveis. O que Paul de Man aponta, segundo Caruth (1996), é que a graciosidade do boneco de movimentos leves e suspensos é a graciosidade de um objeto morto, totalmente passivo. E ele é mais gracioso quanto mais morto for (mais dócil e passivo). Em Auster, essa graciosidade é perdida, talvez possivelmente enlutada, o que não deixa de sinalizar alguma esperança, caso se consiga se resistir a essa melancolia à espreita, como um chão negro que se abre sob os pés.

\footnotetext{
${ }^{9}$ Cf. Caruth, "The falling body and the impact of reference", in Unclaimed Experience: Trauma, Narrative, and History, 1996.
} 
E eis que escutamos o primeiro choro de Auster, mas um choro deslocado, fora de lugar, mas que traz profundas ressonâncias e condensações de sentido.

Auster se lembra de sua viagem a Amsterdã. Lá, “por acaso”, perdera-se nas ruas circulares (como os infernais círculos da memória). Resolve, como que do nada, visitar o quarto - tornado museu - de Anne Frank. De repente, olhando para as fotos desbotadas de estrelas de Hollywood que ela colecionara, ele se viu chorando: "Não soluçava, como pode ocorrer em reação a uma profunda dor interior, mas chorava sem fazer barulho, as lágrimas corriam pelas faces, como que em uma pura reação ao mundo.” (Auster, 1982, p. 95) Auster não chora por seu pai (será?), mas pelo confinamento e sofrimento de uma alma, vida e sonhos brutalmente interrompidos. O terror desse quarto, o que a espreitava lá fora, e que se avolumava e se aproximava em ondas de pesadelo, em marcha. A menção à Segunda Guerra Mundial e à morte dos judeus, representados e condensados no quarto de Anne Frank, insere o sofrimento da menina numa cadeia de desamparo e violência cuja origem e fim não sabemos muito bem onde começa e termina. No transcorrer do livro, aparecem sucessivas séries de crianças em desamparo, da guerra no Camboja até crianças não nascidas.

Algumas crianças são particularmente lembradas, crianças que não conseguiram ser salvas por seus pais: Anatole (filho de Mallarmé), Titus (filho de Rembrandt), Mur (filho da poetisa Marina Tzvetáieva)...

As lembranças dessas são intercaladas com as de seu filho, Daniel.

Cada vez mais, Auster vê em Daniel a si mesmo. Porém, vê também seu pai no filho Daniel, seu pai olhando para ele, Auster, a partir de sua infância em Kenosha. Presente, passado e futuro são paredes transpostas, de uma só vez, pela imaginação-memória que religa as gerações.

Sam Auster também foi aquele que não conseguiu ser salvo (Auster não diz, mas poderíamos assim entender).

A meditação no quarto leva Auster a percorrer imagens de salvação e redenção em outras figuras literárias. Pinóquio encontra Gepeto na barriga do tubarão, onde já a esperança tinha começando a se apagar, da mesma forma que a última vela acesa que ainda sobrara dos mantimentos do navio. Com o pai em suas costas, Pinóquio nada para fugir do ventre do tubarão (que é uma baleia, na versão em desenho da Disney). Uma fantasia (talvez um delírio) de um filho salvando e mesmo permitindo o (re)nascimento do pai.

Nessa imbricação de gerações, de história e dramas coletivos e pessoais, de figuras literárias, bíblicas e fantasmáticas, Auster se reúne numa encruzilhada ao lado de muitos personagens e companheiros de viagem... e chora. 
Ele quer salvar também seu pai, salvar o pai que o filho, Daniel, faz lembrar, e também ser salvo por ele. Reinserindo essa dimensão traumática, de perdas e mutilações muito concretas, numa narrativa simultaneamente literária e histórica (autobiográfica), Auster permite que uma temporalização possa ocorrer, numa espécie de descongelamento e reabertura da história, em seu devir ${ }^{10}$. Nesse caso, a perda do pai - um evento histórico identificável - deixa de ser confundida com uma ausência constitutiva do existir. Aqui, está em jogo uma possível passagem e trânsito de uma melancolia infinita a um luto possível.

Em Auster, os giros que a memória perfaz, a cada volta do carretel, puxam e enlaçam diversas dimensões da existência, e arrastam consigo os personagens ao redor. O choro é de Paul Auster... mas também é de seu pai, Sam Auster, é de Mallarmé, é de Anne Frank, é de Anatole, é de Van Gogh... é nosso.

As diversas figuras dos quartos, embora possam dar margem e também comportem as imagens da cela, do claustro, do aprisionamento, da mônada leibniziana, também abre espaços para outras modalidades do recolhimento (o lugar do repouso, do sono, do sonho, da escrita, da hospitalidade, do castelo da alma, como em Teresa D’Ávila etc.). Assim, o extremo vazio do quarto da rua Varick se transforma em condição de possibilidade e abertura de um sonhar não preso às dimensões físicas, um sonhar sensível e imaginativo o suficiente para ser tocado por outros “quartos”.

A fina sensibilidade de Auster aos gritos silenciosos, impedidos de serem vocalizados, pode ser notada assim, por exemplo, em sua apreensão de um dos quadros de Van Gogh (um da série “o quarto de dormir”), que merece ser citada na íntegra.

A primeira impressão de A. foi de fato uma sensação de calma, de "repouso", como o artista a descreve. Mas aos poucos, à medida que tentou habitar o quarto apresentado na tela, começou a experimentá-lo como uma prisão, um espaço impossível, uma imagem não tanto de um lugar para morar, mas sim da mente que foi forçada a viver ali. Observe com cuidado. A cama bloqueia uma porta, a cadeira bloqueia a outra porta, a janela está fechada: não se pode entrar e, uma vez lá dentro, não se pode sair. Sufocados no meio dos móveis e dos objetos do dia-a-dia no quarto, começamos a ouvir

\footnotetext{
${ }^{10}$ Aqui, é interessante mencionar a diferenciação que LaCapra (2001) faz entre ausência e perda, e os riscos de se confundir uma com outra. A ausência, para LaCapra, situa-se num nível trans-histórico e constitucional do existir, não podendo ser contornado ou ultrapassado, mas apenas enfrentado. Elenca-se, aí, entre outros signos dela, a ausência de fundamentos absolutos do existir (de origens plenas, de destinos teleológicos etc.). As perdas, por sua vez, são sempre historicamente localizáveis como eventos, mas são acontecimentos que abrem a possibilidade de serem retomados, relativamente recuperados, relativamente reparados etc. Todavia, quando a ausência é identificada como perda, então emergem todos os processos de mitologização, de tentativas de se recuperar um passado pleno e puro etc. Ao contrário, quando uma perda é convertida em ausência, perde-se de vista o caráter único, singular, desse evento, o qual passa ser inserido numa zona indiferenciada de ausências que fariam supostamente parte do humano, num nível trans-histórico. Como um exemplo, o Holocausto perderia sua singularidade e seria mitologizado como um episódio a mais da já conhecida decadência e violência do homem.
} 
um grito de sofrimento nessa pintura e, uma vez que o ouvimos, ele não pára mais. 'Gritei por causa de minha angústia [...].' Mas não há resposta para esse grito. $\mathrm{O}$ homem nessa pintura (e é um auto-retrato, em nada diferente do retrato do rosto de um homem, com olhos, nariz, lábios e queixo) ficou tempo demais sozinho, debateu-se tempo demais nos abismos da solidão. O mundo termina na porta bloqueada. Pois o quarto não é uma representação da solidão, é a própria substância da solidão. E é uma coisa tão pesada, tão irrespirável, que não pode de modo algum ser mostrada em outros termos senão naquilo que é. ' $E$ isso é tudo - não há nada nesse quarto com a janela fechada [...]’. (Auster,1982, p.160).

É interessante mencionar que, num outro contexto, Didier Anzieu, famoso psicanalista, também notara e apreendera a profunda dor e o vazio ilustrados pelas pinturas do quarto de dormir de Van Gogh. Para Anzieu (1985), a série de quadros do quarto de dormir, embora ainda uma espécie de autorretrato em negativo, como que já prenunciariam uma ausência final, a morte decorrente dos ferimentos na suposta tentativa de suicídio.

O quadro do quarto de dormir é um auto-retrato, não mais o retrato do pintor presente a si mesmo, mas o retrato do pintor que se ausenta de sua obra e logo mais de sua vida. É a representação de uma alucinação negativa: a pintura absorve e faz desaparecer o pintor no nada [néant]' (1985, apud Figueiredo, 2014, p.93).

Numa sucessão de equivalências, os quartos arrastam diversos gritos dentro si (inclusive o seu), e ao mesmo tempo um só, o de seu pai.

Conforme a obra de Auster avança, os gritos e os fantasmas vão se avolumando na forma de personagens, pois também estes se transformam em espectros a assombrar o autor. Em Viagens no scriptorium, o personagem principal, em seu quarto - que não se sabe até o final do livro se é uma cela, um quarto de hospital, um sanatório ou o uma alucinação -, é visitado por fantasmas que são claramente as vozes e imagens de personagens de Paul Auster, enviados, livro após livro, para diferentes missões, em busca de outros desaparecidos, e reaparecem como personagens em busca de um autor, para parafrasear a peça de Pirandello (1921). Mas também podem ser a marcha de outros refugiados, de outros povos, caminhando para não se sabe aonde, vindos de lugar nenhum. A instabilidade e a indecisão quanto à origem e ao destinatário do texto, caráter por excelência da literatura, comparece aí com toda força e expressividade.

O quarto como equivalente do livro, ou como o local onde o livro se escreve, ou como claustro, ou como útero para o renascimento, ou como esconderijo, ou...

Ainda em Amsterdã, Auster, da janela do quarto de Anne Frank, vê os fundos de outra casa, onde há um quintal, com brinquedos para crianças. É o fundo de uma casa onde 
Descartes chegou a morar. À sombra de dois quartos - um como signo do sofrimento sem sentido, outro como emblema da racionalidade ocidental -, um playground. Nesse intervalo entre dois quartos, duas janelas, Auster medita como seria para uma criança crescer sob a sombra do quarto de Anne Frank ${ }^{11}$. Como crescer sob a herança de um sofrimento insustentável? Do outro lado, a cumplicidade de outro olhar, o olhar da Razão tornada método. No intervalo, o lugar do brincar (da literatura?), entre a "seriedade” e o sofrimento. No choro de Auster em "seu” quarto (de quem é o quarto?), reúnem-se muitos outros quartos, muitos outros choros.

Precisaríamos aceitar que o quarto poderia ser melhor descrito como uma casa com múltiplos aposentos. Na casa do Pai, há muitas moradas.

\footnotetext{
${ }^{11}$ Auster, embora não assuma diretamente a sua condição de judeu, ainda assim herda a sombra dessa tradição e o que está vinculado a ela.
} 


\section{Retrato de um homem em ruínas}

Todos achavam que ele tivesse morrido. Quando meu livro saiu, em 1988, fazia quase sessenta anos que não se tinha notícia de Hector Mann. À exceção de um punhado de historiadores e amantes do cinema antigo, pouca gente parecia saber que ele existira. Double or Nothing, a última das doze comédias de curta-metragem que fez já no fim da era dos filmes mudos, foi lançada em 23 de novembro de 1928. Dois meses depois, sem se despedir de amigos ou colegas, sem deixar carta ou bilhete nem informar ninguém de seus planos, saiu da casa que alugava na North Orange Drive e nunca mais foi visto. O DeSoto azul estava estacionado na garagem; a locação era válida por mais três meses; o aluguel fora pago até o fim do contrato. Havia comida na cozinha, uísque no bar e não faltava uma única peça de roupa nas gavetas e no guarda-roupa. Segundo o Los Angeles Herald Express de 18 de janeiro de 1929, a impressão era a de que ele tinha dado uma saída e voltaria a qualquer momento. Mas não voltou, e desse ponto em diante foi como se Hector Mann tivesse sumido da face da Terra. (Auster, 2002, p. 7; itálicos no original).

Recorrente em Auster, como já havíamos apontado, pessoas desaparecidas se amontoam em suas estórias, em escombros acumulados de ausências. Seus vestígios, como rastros fugidios, são, entre outros, os objetos pessoais paradoxalmente já sem donos. Notícias de um passado enigmático, marcas de almas cujo súbito desaparecimento talvez indique uma igualmente incerta e enigmática fratura. Além disso, cesuras, cortes no tempo, mudanças abruptas de rota, de vozes narrativas e quedas que interrompem existências desde então malogradas talvez sejam signos de alguma outra coisa, mas que seria apressado - talvez também incerto - nomear.

Estamos às voltas com mais um desaparecido, com mais uma figura espectral. E poderíamos dizer que seria espectral em muitos sentidos, tanto por seu desaparecimento misterioso, quanto pelo fato dessa figura em questão, um dos personagens centrais de $O$ livro das ilusões, Hector Mann, ter sido um ator do antigo cinema mudo, um gênero igualmente quase morto. Mas se deve, também, além disso, numa espécie de acúmulo de camadas fantasmáticas, pelo fato de seu passado - como de seu paradeiro - ser de origem altamente duvidosa. Imigrante de nacionalidade desconhecida, multiplicavam-se as versões de sua história e de seu passado, versões essas criadas a partir de seu sotaque espanhol - nunca evidenciado nos filmes, já que seu desaparecimento e término de carreira se deram antes do surgimento do cinema falado. Esse sotaque, alguns diziam, teria sido um obstáculo para a sustentação de seu sucesso, caso a carreira de Hector vingasse na nova perspectiva aberta pelo som, o que, de alguma forma, já anunciava seu ocaso. 
Pulverizado numa diversidade de versões de si mesmo, muitas vezes com seu consentimento e sua irônica ajuda, Hector era apreendido, nos dias de seu rápido estrelato, com diferentes vestimentas quanto à sua origem: antes de chegar à Califórnia, teria passado por Buenos Aires, Brasil e México, percorrendo uma carreira artística em turnês pela América. Teria vindo buscar a vida em Hollywood, na onda sempre recorrente do sonho da fortuna e da fama, mas já com alguma carreira anterior consolidada. Algumas outras versões eram tecidas com o intuito de diminuí-lo; outras, claramente já escancaravam o elogio e a sedução que a figura do Latin lover (mesmo que um sedutor quase de segunda) exercia sobre as indefesas donzelas. Tais versões, contraditórias entre si, tinham o aval e participação intencional do galã, que não hesitava em reformular seu passado segundo lhe convinha e segundo quem era o(a) entrevistador(a). Para uma repórter fascinada e seduzida, seu perfil garboso e seu galanteio eram prontamente incorporados, o que não deixava de lhe acentuar certa aura e diferença em relação a outras figuras dos filmes cômicos do cinema mudo. Hector tinha algumas peculiaridades que o diferenciavam dos demais atores, embora algumas fontes reais tivessem inspirado Auster para compor o personagem, numa mistura peculiar de algumas personalidades cômicas, o que exporemos a seguir. Mesmo assim, Hector

... era muito alto para fazer o rematado palhaço e bonito demais para interpretar o trapalhão inocente. De olhar expressivo e nariz elegante, parecia um galã, não um cômico. Comediantes eram homens baixinhos ou gordos, crianças disfarçadas de adultos ou adultos com mentalidade de criança. Hector era diferente: um boa-pinta irresistível, tanto dentro quanto fora da tela - daí talvez o motivo da sua desgraça. (Auster, 2002, p. 37)

Tais traços sedutores, que lhe farão cair em “desgraça”, também lhe confeririam um poder de atração para além do galanteio. Sua figura suscitou e atraiu, mesmo que com sua curta carreira - cerca de um ano e pouco -, algum interesse (ainda que superficial) de críticos, repórteres e... David Zimmer, o narrador do Livro das Ilusões, que também narra outros personagens narrando uns aos outros. Assim, desde o início adentramos num universo com vozes narrativas múltiplas, sem ponto fixo, narradores que, veremos, tornar-se-ão também altamente não confiáveis, suspeitos.

O ator, de uma rápida trajetória no cinema mudo, cujo desaparecimento misterioso se deu em 1929 (mesmo ano da crise financeira que assolou o país), deixou atrás de si enigmas e imagens fugidias (sua biografia, incerta; as fotos, poucas e esparsas). Ainda quanto às versões fragmentadas a seu respeito, Brigid O’Fallon, repórter e futura vítima de seu ar sedutor, destacara o sotaque espanhol carregado de Hector. Em outra versão, de outro jornalista, tal 
sotaque não mais existia, e o entrevistador destacava, atônito: “essa máquina argentina de provocar risadas fala um inglês impecável, quase sem o menor vestígio de sotaque. Se você não souber de onde ele é, vai jurar que nasceu e se criou em Sandusky, Ohio.” (Ibid., p. 84, itálicos no original). Essa versão, contudo, desfaz a ideia de que ele tivera chegado há pouco tempo aos EUA, dando a entender, ao contrário, que sua estada era tão antiga a ponto de ter se tornado, por uma assimilação profunda, um típico cidadão de uma típica cidade americana.

Em sua última entrevista, numa revista de título sugestivo (os nomes sempre contarão alguma história em Paul Auster), Picture Play, o jornalista relata Hector como sendo natural de Stanislav, na porção leste do Império Austro-Húngaro, e sua primeira língua teria sido o polonês, e não o alemão, conforme outros relatos. A família teria partido para Viena, instalado-se aí durante dois anos para, então, ir para os Estados Unidos, primeiro em Nova York, e depois no Meio-Oeste americano. Quando perguntado qual cidade do Meio-Oeste, Hector responde, calmamente, "Sandusky, Ohio”. O que teria sido, anteriormente, num artigo a seu respeito, apenas uma metáfora de um repórter para classificar o bom domínio da língua e da cultura por parte de Hector torna-se, então, quase por decreto, uma de suas cidades de infância. Hector adota uma metáfora como sua origem. Ficção, realidade, narrativas de terceiros (com as ênfases e as distorções mais ou menos carregadas)... tudo se embaralha, e o jogo de esconde-esconde e o contar estórias se misturam para formar um quadro multifacetado...

Ele se mostra intransigente e prático num relato; temeroso e sentimental no outro. É encrenqueiro para um jornalista, obediente e devoto para o outro; foi pobre, foi rico; fala com forte sotaque, fala com sotaque nenhum. Juntando-se todas essas contradições, terminamos de mãos vazias, com o retrato de um homem com tantas personalidades e histórias familiares que acaba reduzido a um monte de fragmentos, a um quebra-cabeça cujas peças não se encaixam mais. (Auster, 2002.)

Aos poucos, essas versões múltiplas e o próprio título do livro (que faz menção ao caráter ilusório de si mesmo) ensejam uma postura desconfiada do leitor, como se uma nuvem de fumaça cobrisse os personagens e as histórias narradas. Smoke (1995), um dos filmes de Paul Auster, já trazia essa dimensão “enevoante” que recobre e religa os personagens, numa atmosfera de proximidade etérea e enigmática, capaz de produzir miragens e ilusões. Aqui, a cortina de fumaça produz um nevoeiro formado de imagens bruxuleantes, que se combinam e se transformam a cada narrativa. Por que Hector insiste nesse jogo?...

Toda vez que alguém lhe faz uma pergunta, ele dá uma resposta diferente. As palavras jorram de sua boca, mas está decidido a jamais dizer a mesma 
coisa duas vezes. Parece estar escondendo algo, protegendo um segredo, no entanto leva adiante o ofuscamento com tamanha sutileza e bom humor tão borbulhante que ninguém parece notar. Os jornalistas não resistem a seu charme. Ele os faz rir, diverte-os com pequenos truques de mágicas e, depois de certo tempo, a imprensa pára de pressioná-lo a respeito dos fatos e cede ao poder de sua atuação. Hector continua seu vôo disparado, passando loucamente dos paralelepípedos das avenidas de Viena para a planura eufônica de Ohio e, aos poucos, você começa a se perguntar se isso seria um jogo de enganos ou simplesmente uma tentativa equivocada de espantar o tédio. Quem sabe as mentiras fossem inocentes. Quem sabe não estivesse tentando enganar ninguém, e sim buscando uma forma de se divertir. Ser entrevistado pode ser um negócio enfadonho, afinal de contas. Se todo mundo fazia as mesmas perguntas, talvez julgasse necessário inventar as mesmas respostas, para permanecer acordado. (Auster, 2002, p. 86, itálico meu).

Um pequeno desvio... nossa primeira torção. Um desvio para "trás”, para a autobiografia ficcional de Auster sobre sua relação com o pai. Somos confrontados (também iludidos?) com a semelhança da descrição de Hector feita por Zimmer com a atitude jocosa, escorregadia e sempre um pouco autoficcionalizante do próprio pai de Auster. A tentação, quase irresistível, é tomarmos o senhor Sam Auster como a matriz de Hector, ou, antes e mais radicalmente, como a primeira versão de Hector, se entendermos com isso que, também quanto a Sam Auster, já estaríamos no plano de um testemunho que se aproxima de - e mesmo se transfigura em - uma narração ficcional ${ }^{12}$. Sam Auster, desde a origem, seria já uma ficção (inventada?), mas uma que recebe esse nome não apenas por conta de um capricho artístico, mas também em decorrência de uma lacuna e uma ausência essenciais, que só poderiam ser atravessadas (ou talvez circundadas, tangenciadas) com a ajuda da ficção Uma dupla produção-exigência de ficção. Tanto a testemunha dessa ausência (no caso anterior, o filho Paul Auster em relação ao pai, Sam) quanto o próprio objeto de testemunho estariam secretando algo tóxico, contaminando a "realidade” com o veneno da ficção, da literatura (doentia ou terapêutica).

Mas voltemos ao nosso caminho...

Dos quatro artigos de jornais que contam algo da história de Hector, David Zimmer, o narrador do livro, e que sabemos que também é um dos narradores, investigadores e, quem sabe, uma testemunha (mesmo que tardia) de Hector, encontra um padrão: Hector evita falar da sua cidade-natal, distraindo os jornalistas quando eles se aproximam desse território (perigoso?). Um padrão marcado pela ausência e pela omissão, pela falta de detalhes e descrição de nenhuma cidade, nenhum povoado, a não ser Stanislav, que fazia parte do

\footnotetext{
${ }^{12}$ Como vimos no texto anterior, o livro A invenção da solidão situa-se numa difícil e talvez não delimitável fronteira entre a autobiografia e a ficção.
} 
Império Austro-Húngaro, mas que depois tinha sido entregue a Polônia, com a dissolução do Império depois da guerra. Zimmer tateia uma possível origem judaica para Hector Mann, o que se confirmaria posteriormente no livro, quando ficamos sabendo que seu "verdadeiro" nome, quando de sua jornada antes de vir para a América, era Chaim Mandelbaum. Essa condição judaica, contudo, torna-se renegada e avessa a qualquer aproximação de terceiros. Dupla condição de exílio: da própria terra de origem e da própria origem judaica. Uma ferida com poucos contornos aparece aí, um mal-estar pouco claro e pouco nítido, escorregadio, não assumido.

Porém, mesmo que escorregadias, esquivas, as feridas, ainda assim, não deixam de sangrar e de atrair os personagens para buracos negros, inclusive buracos de ausência.

O livro, do começo ao fim, vaga entre diferentes histórias que, ainda que contadas por Zimmer - o que as torna, no fundo, sempre mediadas por esse narrador -, não deixam de focalizar outros dramas. Mas precisamos nos deter nesse narrador, David Zimmer, cuja aparição aqui no nosso texto guarda algo da hábil esquiva de Hector. Quem é David Zimmer?

Professor universitário e escritor, sua obra e interesse encaminhar-se-iam em direção à história de escritores que "abandonaram o ofício, [a] uma meditação sobre o silêncio” (Ibid., p. 19). Essa menção ao silêncio, a uma espécie de fascinação pela dificuldade e/ou impossibilidade da escrita, não deixa de ser interessante e de fornecer uma espécie de predisposição do narrador-personagem à dimensão da impossibilidade do dizer. Zimmer publicara um livro sobre Hector Mann, intitulado O mundo silencioso de Hector Mann, um trabalho acadêmico que se detivera apenas nos filmes do ex-ator, então desaparecido, sem se importar com sua biografia. Mas o que Hector desperta em Zimmer, a ponto de fazê-lo suspender o interesse pela literatura para se dedicar a um estudo de um ator secundário de um gênero então quase completamente morto?

Zimmer vive o luto e o pesar da morte de sua esposa e seus dois filhos, que sofreram um acidente de avião. A fatalidade de uma queda que desgoverna o mundo do personagem. $\mathrm{O}$ intenso sofrimento, narrado de forma seca, aparece, silenciosamente, no modo como Zimmer tenta vestir as roupas da esposa e, ao mesmo tempo, brincar com os brinquedos dos filhos, numa vã e desesperada tentativa de invocar a presença para sempre ausente da família. Os objetos como a materialidade de espíritos que disseram adeus.

Dor irremediável. Sofrimento indizível. Vidas interrompidas.

Mais uma perda histórica, cuja força, tal como o olhar da Górgona, atrai a visão e petrifica o ser, conduzindo e convidando a perda a mergulhar no buraco da melancolia (mais uma vez, no mesmo compasso fúnebre de A invenção da solidão). 
A um passo da morte, de outro vazio, de outro nada, Zimmer, depara-se, ou melhor, é visitado pela figura de Hector quando assiste a um documentário televisivo sobre o cinema mudo. Hector aparece como um ator secundário, ao lado de outras figuras proeminentes e de outras igualmente pouco conhecidas. Entre os notórios, nomes como Buster Keaton, Chaplin e Max Linder. Entre os menos proeminentes, Raymond Griffith e outros.

Após uma hibernação e um período de glaciação, uma fagulha de calor, espontaneidade e, talvez, vida (ou sua promessa): Zimmer soluça um riso ao assistir às tribulações de Hector, sem ao certo saber se esse espasmo seria apenas o último suspiro da alma antes de deixar o corpo ou se era alguma espécie de cartão de visita da vida em todo seu risco (e algum riso). De qualquer forma, um acontecimento, um evento digno de lhe proporcionar algum interesse e uma retomada de seu empreendimento literário. Zimmer se dedica a fazer um estudo sobre a curta obra de Hector.

Mas podemos nos deter e demorarmos um pouco nesse riso, ou, antes, nessa comicidade capaz de proporcioná-lo. O que poderia estar em jogo nos filmes cômicos do cinema mudo que fosse capaz de funcionar como um minidesfibrilador para Zimmer? E o que, em Hector especificamente, poderia ter reanimado Zimmer?

Ora, a óbvia e primeira resposta seria o poder e força da arte como dispositivo de elaboração e de reconstituição narcísica. Essa, é verdade, parece ser uma das temáticas de fundo do livro (e poderíamos mesmo dizer da obra de Auster como um todo): arte, vida e morte. O poder redentor da arte, seus perigos e ciladas, suas insuficiências, sua culpa, impasses, limitações e traições etc. Tudo isso percorre o livro. Todavia, como numa noite em que todos os gatos são pardos, ganhamos em generalidade e perdemos em especificidade. Por que o cinema mudo e os filmes cômicos do gênero? Que possíveis mundos, para brincarmos com a inspiração heideggeriana, tais obras abririam, possibilitariam ou refletiriam?...

Sigamos Auster, quer dizer, Zimmer para acharmos alguma possível resposta...

... enquanto via Hector e outros comediantes mostrarem o que tinham de bom, entendi que eu era testemunha de uma arte morta, de um gênero extinto que nunca mais seria posto em prática. No entanto, apesar de todas as mudanças, o trabalho deles continuava tão novo e empolgante quanto na época de sua primeira exibição. $\mathrm{E}$ isso porque haviam entendido a linguagem que estavam falando. Inventaram uma sintaxe do olho, uma gramática do puro movimento, e, exceto pelos trajes, carros e pela mobília antiquada em segundo plano, nada daquilo chegaria jamais a envelhecer. Era pensamento traduzido em ação, a vontade humana expressando-se através do corpo humano e, portanto, era para toda a vida. A maioria das comédias mudas mal dava-se ao trabalho de contar uma história. Eram como poemas, expressões de um sonho, eram uma intricada coreografia do espírito, e, por estarem mortas, provavelmente nos falavam mais fundo do que às plateias de seu 
tempo. Víamos essas comédias através de um enorme abismo de esquecimento, e as coisas que as separavam de nós eram o que, na verdade, as tornavam tão fascinantes: a mudez, a ausência de cor, os ritmos espasmódicos, acelerados. Obstáculos, sem dúvida, que dificultavam o ato de assistir, mas também aliviam as imagens do fardo da representação. Como ficavam interpostos entre nós e o filme, não precisávamos mais fingir que estávamos olhando para o mundo real. A tela plana era o mundo e esse mundo existia em duas dimensões. A terceira estava em nossa cabeça. (Auster, 2002, p. 21; itálico nosso).

Fiquemos nessa descrição dos interesses mais ou menos explícitos de Zimmer sobre o cinema mudo, sem cor, e sobre Hector. Algumas imagens se fazem presentes aí e talvez possamos delinear algumas.

O filme mudo, em preto e branco, artefato de um passado que, ainda que revisitado, está morto, nos faz ouvir uma voz silenciosa longínqua, ecos de um tempo outro, de outro lugar. É recorrente em Auster essa ideia de um texto se dirigindo a um destinatário sempre incerto de receber essa mensagem, como também a da escrita de um desaparecido, na perseguição literária de um espectro. Mas quem estaria destinando uma mensagem? E qual seria essa mensagem?

O filme mudo cômico, com suas gags e suas estórias enxutas, como um poema, condensariam uma multiplicidade de imagens e mesmo sensações, talvez contraditórias. Em primeiro lugar, há a clara associação entre o silêncio, a falta de cor e de som com as imagens de ausência, morte, fantasma etc. Frente a esse silêncio, o escritor se sente compelido a preencher o vazio com suas palavras. Há um fascínio e um temor (e terror) simultâneos.

Bilton (2011), num interessantíssimo ensaio ${ }^{13}$ sobre o Livro das Ilusões, comenta o estranhamento que as primeiras imagens do filme em preto e branco causaram em alguns proeminentes pensadores e escritores. Entre esses, cita Gorky, em seu famoso ensaio "The Kingdom of Shadows":

É um mundo sem som, sem cor. Tudo aí - a terra, as árvores, as pessoas, a água e o ar - é mergulhado num cinza monótono. Raios cinzentos do sol cruza o céu cinza ,olhos cinzar em faces cinzas, e as folhas das árvores é um cinza pálido. Silenciosamente, a foligem cinza-pálida das árvores balançam ao vento, e as silhuetas cinzas das pessoas, como que condenadas ao eterno silêncio e sendo cruelmente punidas por ser privadas de todas as cores da vida, deslizam silenciosamente pelo chão cinza... Diante de você uma vida está surgindo, uma vida privada de palavras e podada do espectro vivo das

\footnotetext{
${ }^{13}$ Valho-me, aqui, das sugestivas e interessantes análises de Alan Bilton acerca da recepção do cinema mudo para diferentes pensadores, bem como sua investigação da proximidade e mesmo a provável inspiração de Auster em outros personagens, fundamentalmente, Buster Keaton, Max Linder e Raymond Griffith, para a composição de Hector Mann. Assim, à galeria de matrizes de inspiração, ao lado de seu pai, Sam Auster, outros personagens darão suas caras.
} 
cores - o cinza, a ausência de ruído, o deserto e a vida lúgubre. É aterrorizante ver, mas é o movimento das sombras, apenas das sombras. Pragas e fantasmas, os espíritos do mau que lançaram cidades inteiras o sono eterno vêm à mente. (Gorky apud Bilton, 2011, p. 249).

A ausência de cor e som levando a certa modalidade fantasmática de vida, nessa espécie de umbral em que muitos personagens de Auster habitam. Em Auster há um confronto constante com o vazio e a negação. Não é preciso grandes acrobacias retóricas para perceber aí um convite a Zimmer se aproximar do cinema mudo, para além de seu interesse cinematográfico apenas. Nas bordas do abismo, antes da queda, ou mesmo já decaído e vagando como uma entidade desencarnada, Zimmer encontra no cinema mudo as cores de sua alma. Cada vez mais em Auster, ou talvez desde o início, os lugares e os ambientes também contarão uma história. Do quarto fechado, tal qual cela, em Trilogia de Nova York, passando pelo quarto inóspito em que escreve suas memórias sobre o pai, em $A$ invenção da solidão, ganhando as ruas de Nova York com sua multidão de estranhos e de objetos quebrados, até chegar ao ambiente desértico do Meio-Oeste americano, a ambientação dos cenários sempre fornecerá um solo de ancoragem ou de perdição, talvez uma ambiência, uma atmosfera, que mergulha a todos e narra, silenciosamente, os estados de alma dos personagens.

Há, ainda, nessa conjunção entre o torpor de Zimmer e a imagem do cinema mudo como uma relíquia de um passado antigo - que nos falaria mais profundamente justamente por causa dessa distância - a ideia de um tempo estacionado, que, mesmo que longínquo, não passou. Talvez houvesse aí a ideia de uma estagnação, uma suspensão da vida.

Porém, e paradoxalmente, também há uma ênfase sobre essa "nova gramática do puro movimento” e uma acentuação sobre a dimensão corporal da existência, com todas suas dificuldades, impasses e descompassos. Há uma intensidade e um frenesi nos movimentos dos personagens do cinema cômico mudo. Acelerações, rodopios, quedas, malabarismos, tropeços, cambalhotas... uma dança obstinada cujos passos sempre se dão a partir do desequilíbrio e de certo desajuste com o mundo. Nas cores mortas do cinema mudo, há entranhada uma exasperação dos movimentos.

Em Hector, é verdade, esses movimentos, para aquém das atrapalhadas, são elegantes e muito finos, comunicando estados de alma e seus pensamentos a partir das cordas de seu instrumento musical corporal mais precioso: seu bigode:

Filamento irrequieto de ansiedades, corda de pular metafísica, linha dançante de saracoteios, o bigode é o sismógrafo de seus estados de espírito, e não só nos leva a rir como nos diz o que Hector está pensando, nos permite entrar na engrenagem das suas idéias. Há outros elementos envolvidos - os olhos, a 
boca, os arrancos e tropeções habilmente calibrados -, mas o instrumento de comunicação é o bigode e, mesmo falando uma linguagem sem palavras, contorções e tremeliques são tão claros e compreensíveis quanto uma mensagem em código Morse. [...] A boca se curva de leve nos cantos, as narinas inflam muito ligeiramente, mas durante os momentos em que o bigode efetua seus giros mirabolantes o rosto continua essencialmente parado e, nessa imobilidade, nos vemos como num espelho, porque é justamente nesses instantes que Hector se mostra mais total e convincentemente humano, um reflexo daquilo que todos nós somos quando estamos sozinhos dentro de nós mesmos. (Auster, 2002, pp.33-34, itálico meu).

Um jogo floreado de imobilidade e movimento, de congelamentos e erupções finas, o rosto e o bigode de Hector poetizam e comunicam seus estados de alma, são, segundo Zimmer, “a conexão com seu interior” (Ibid., p. 36).

Outro elemento, agora mais voltado para a relação com mundo externo e signo de vulnerabilidade de sua existência aos caprichos imprevisíveis da vida, seria o seu terno branco. Cândido, imaculado (mas sempre um alvo e à beira da inscrição das tintas da vida), tal terno branco não deixa de se assemelhar às vestimentas brancas de outro personagem, Peter Stillman Jr, cuja brancura talvez possa simbolizar essa sonhada perfeição para sempre perdida. Mas Hector...

o enverga todas as manhãs da mesma forma que um cavaleiro enverga sua armadura, preparando-se para sejam quais forem as batalhas que a sociedade tenha lhe reservado para aquele dia, e nem uma vez sequer se detém para pensar que está alcançando o oposto do que pretende. Hector não está se protegendo contra possíveis golpes, mas se transformando num alvo, no centro de qualquer desastre que possa vir a ocorrer nos cem metros a sua volta. O terno branco é um sinal da vulnerabilidade de Hector e empresta certo páthos às peças que o mundo lhe prega. Obstinado em sua elegância, aferrado à convicção de que o terno o transforma no mais atraente e desejável dos homens, Hector eleva a própria vaidade a uma causa com a qual as platéias podem simpatizar. Observe-o espanando flocos de poeira imaginária do paletó enquanto toca a campainha da cada da namorada em Double or Nothing: você não está mais vendo uma demonstração de narcisismo, está testemunhando os tormentos do constrangimento. O terno branco faz de Hector um pobre-diabo. (Auster, 2002., p. 36).

Há em Hector, em seus filmes, uma tentativa de se adequar aos ditames da sociedade, o que se vincula ao seu sonho de fama, estrelato e assimilação à cultura norte-americana. Se há uma elegância nos seus maneirismos e em sua vaidade (a qual, contudo, sempre acionará o riso quando exacerbada), e mesmo uma disposição para a socialização, ainda assim algo sai errado...

... ele é uma vítima das circunstâncias, um homem com um talento inesgotável para o azar. Hector tem sempre um plano em mente, um motivo 
para fazer o que faz, entretanto, alguma coisa sempre acaba aparecendo para impedi-lo de alcançar seu objetivo. Seus filmes estão cheios de ocorrências físicas, falhas mecânicas estapafúrdias, de objetos que se recusam a se comportar como deveriam. Um homem com menos confiança em si mesmo seria derrotado por esses revesses; no entanto, fora uma ou outra explosão de exaspero (limitada aos monólogos do bigode), Hector nunca se queixa. Portas se fecham em seus dedos, abelhas picam-lhe o pescoço, estátuas caem sobre seus pés, e toda vez ele dá de ombros aos infortúnios e continha seu caminho. Você começa a admirá-lo pela tenacidade, pela calma espiritual que se apossa dele diante da adversidade, mas o que segura a atenção é a forma como ele se move. [...] Leve e ágil, despreocupado a ponto da quaseindiferença, embrenha-se pela pista de obstáculos da vida sem o menor vestígio de desaire ou medo, fascinando a plateia com seus recuos e evasivas, suas súbitas arrancadas e pavanas arrebatadas, suas segundas olhadelas espantadas, seus passinhos saltitados e sua ginga rumbeira (Auster, 2002., p. 38).

Há uma irresistível atração que nos puxa para as peripécias de atores, diretores e escritores ${ }^{14}$ como Chaplin ou Keaton. Precisamos, um pouco que for, investigar esse fascínio em que, também nós, sob influência de Zimmer, nos deixamos cair por esses “malabaristas da existência”"15.

Comentaremos esse perfil de Hector, porém iremos seguir Bilton nas referências que ele faz às prováveis fontes de inspiração de Auster para compor Hector.

Comecemos por Buster Keaton, conhecido por seu olhar de pedra, quase congelado, que quase nunca ri. Uma impassibilidade frente aos desvarios da existência sustenta e guia sua passos. Como em Auster, o mundo de Keaton é permeado por mudanças sem sentido, quase num regime de absurdo, sendo desmantelado e desfigurado a cada momento, tal como um setting de filmagens (Bilton, 2011, p. 240). Em The Playhouse (1921), Keaton acorda, após um possível sonho, num quarto de dormir, cujas paredes são removidas pela equipe de filmagem. Uma instabilidade estrutural do mundo que talvez alguns críticos marxistas grosseiramente - poderiam identificar como signo e uma profecia da fluidez cada vez maior do capital e da liquefação dos obstáculos a ele. Contudo, seja como for, essa instabilidade marca, o tempo todo, as trajetórias dos personagens de Auster também.

Interessante notar que, ainda em The Playhouse, encontramos aquela dispersão de imagens de si mesmo, como havíamos encontrado numa foto do pai de Paul Auster (e como notamos em Hector). Na apresentação de uma ópera, vemos a figura multiplicada de Keaton, que faz todos os papéis, dos músicos à plateia. Ao olhar a lista com os nomes dos intérpretes, um dos membros da plateia, que também é Keaton, fica espantado ao ver que todos se

\footnotetext{
${ }^{14}$ Digno de nota é o fato de que tanto Chaplin, Keaton, Griffith e... Hector escrevem, dirigem e atuam.

${ }^{15}$ Inspiro-me, para essa imagem ,em um texto do Luis Cláudio acerca do filme o Sétimo selo, cujo original não o acho, e do qual também Luís Cláudio não se lembra de tê-lo escrito. Uma disseminação de ilusões?...
} 
chamam Buster Keaton. Porém, há também em seus filmes uma "geografia dos corpos” (Bilton, 2011, p. 241) que são lançados e atirados, ensejando quase que uma espécie de flutuação. Em Auster, essa trajetória quase antigravitacional, aparece, como mencionamos no texto anterior, em Walt, o menino que levitava de Mr. Vertigo.

Outro a inspirar Auster também fora Max Linder, o ator francês, cujo personagem principal era um dândi galanteador, numa clara proximidade com Hector. Todavia, também a história e final trágicos de Max Linder poderiam ter servido de alguma base para Auster, ou pelo menos prefigurado seu Hector. Max Linder e a esposa tentaram o suicídio por duas vezes, sendo bem-sucedidos na segunda, ao injetarem uma dose mortal de morfina e terem cortado os pulsos. Sua filha, Maude, realizou um documentário sobre a vida e a arte de Max Linder, também numa espécie de testemunho daquele que não mais está aí.

Porém, é em Raymond Griffith, o menos conhecido dos três, que uma maior proximidade se faz notar com Hector. Vaidoso, bem vestido, mas sempre parecendo uma personagem totalmente em desacordo com a paisagem ao redor (em Hands Up!, filme de 1926, seus trajes de gala contrastam ao ponto do absurdo com o cenário do deserto americano, em plena guerra civil, como se ele estivesse no filme errado), Griffith se assemelha ao estilo garboso de Hector. Além disso, Griffith é um mestre na arte de desaparecer, sempre de maneira inusitada, apagando-se da cena de maneira arteira e enigmática. Para ajudar a compor esse quadro de traços apagados, seus filmes, assim como os de Hector, não chegaram todos a ser salvos para posteridade. Por fim, a própria voz de Griffith também reforçava esses mistérios, já que ele só conseguia erguê-la até o tom do sussurro (como um fantasma), provavelmente em decorrência de uma lesão causada por infecção.

Mas, deixando de lado por enquanto a possível melancolia anunciada por essas ausências e fantasmas, insistamos na pergunta: por que rimos? (e também nós rimos nesses filmes!...).

Aumentemos nosso desvio, multiplicando as imagens, fugindo um pouco de Hector e seu destino (nós o tememos também?).

No filósofo Henri Bergson encontramos uma deliciosa e interessante análise das causas do efeito cômico, em seu O riso - ensaio sobre a significação da comicidade, de 1924.

Citemo-lo na íntegra, em duas cenas ainda na abertura do livro.

Primeira cena: 
Um homem, correndo pela rua, tropeça e cai: os outros transeuntes riem. Não ririam dele, acredito, se fosse possível supor que de repente lhe deu na veneta de sentar-se no chão. Riem porque ele se sentou no chão involuntariamente. Portanto, não é sua mudança brusca de atitude que provoca o riso, e o que há de involuntário na mudança, é o mau jeito. Talvez houvesse uma pedra no caminho. Teria sido preciso mudar o passo ou contornar o obstáculo. Mas, por falta de flexibilidade, por distração ou obstinação do corpo, por um efeito de rigidez ou de velocidade adquirida, os músculos continuaram realizando o mesmo movimento quando as circunstâncias exigiam outra coisa. Por isso o homem caiu, e disso riem os transeuntes. (Bergson, 1924, p. 7, itálicos do autor).

Segunda cena, logo em seguida:

Temos agora uma pessoa que cuida de seus pequenos afazeres com uma regularidade matemática. Acontece que os objetos que a cercam foram trocados por algum zombeteiro. Vai molhar a pena do tinteiro e lá encontra lama, pensa que está sentando numa cadeira firme e acaba deitada no assoalho; enfim, age na contramarcha ou funciona no vazio, sempre por um efeito de velocidade adquirida. O hábito imprimira um impulso. Teria sido preciso deter o movimento ou desviá-lo. Mas qual nada: continuou-se maquinalmente em linha reta. A vítima de uma farsa de gabinete está, portanto, em situação análoga à de quem corre e cai. (Ibid., p. 7).

Há uma rigidez mecânica por detrás de ambas as cenas, quando, segundo Bergson, o que se esperaria seria certa "maleabilidade atenta" e uma "flexibilidade viva" para lidar com os acasos. Uma falta de elasticidade, um desajuste, uma falta de acordo com o mundo, uma perda momentânea de adaptação e sintonia. O mesmo efeito cômico, ainda segundo Bergson, podemos ter com o distraído, aquele que, por conta da sua obstinação em não ver o mundo, ou por um atraso, ou por uma fixação em suas ideias, acaba por perder o compasso com a existência ${ }^{16}$. Podem ser sonâmbulos ou pessoas imaginativas, sempre um passo aquém ou além do desenrolar dos acontecimentos. Bergon menciona, entre as várias figuras cômicas, Dom Quixote.

... uma coisa é deixar-se cair num poço por estar olhando sabe-se lá para onde, outra coisa é cair por estar com o olhar fixo numa estrela. Era exatamente uma estrela que Dom Quixote contemplava. [...]. Sim, esses espíritos quiméricos, esses exaltados, esses loucos tão estranhamente razoáveis, fazem-nos rir tocando as mesmas cordas em nós, acionando o mesmo mecanismo interior que era acionado pela vítima de gabinete ou pelo transeunte a escorregar na rua. São eles também corredores que caem e ingênuos que são mistificados, corredores do ideal que tropeçam nas realidades, sonhadores cândidos que a vida espreita maliciosamente. Mas são sobretudo grandes distraídos, superiores aos outros porque sua distração é

\footnotetext{
${ }^{16}$ Lembro-me, aqui, de meu falecido tio que, na remota época em que os pedágios não tinham cancela, certa vez passou batido por uma cabine, sem parar. Foi seguido pela polícia e advertido.
} 
sistemática, organizada em torno de uma ideia central, porque suas desditas também são conexas, conexas pela inexorável lógica que a realidade aplica para corrigir o sonho, e porque assim provocam em torno de si, por meio de efeitos capazes de sempre somar-se uns aos outros, um riso indefinidamente crescente. (Ibid., p.11).

Há, na comicidade, entre outras coisas, certa obstinação, qual não seja, a obstinação da matéria, sua fixidez, inflexibilidade etc., que fazem frente ao sujeito e não correspondem a ele, ou então a do espírito (traços de personalidade, quando exagerados, podem se tornar cômicos, como a vaidade de Hector).

Ora, não teria a melancolia, por sua vez, alguma proximidade com essa obstinação, com essa distração rígida? Estaria assim a melancolia tão distante do riso provocado pelos atores cômicos? Tal riso não esconderia outras coisas? E não comportaria tal comicidade, também, uma espécie de análise de nossa condição existencial mais primordial? Não somos todos nós um pouco desajustados e em descompasso com a vida, por vezes flutuando, por vezes tropeçando em seus blocos de matéria e de acontecimentos?...

\section{Voltemos...}

Mas, afinal, qual seria a obstinação de Hector?... (talvez tenhamos andado distraídos e fugido de nosso ator cômico desaparecido).

A história de Hector é contada por Alma, uma das figuras femininas a exercer um poder também de atração. Alma, que esteve com Hector no rancho do ator nos últimos anos de vida do mesmo, havia buscado Zimmer, de maneira intimidadora, para que este pudesse encontrar Hector, que caminhava para suas últimas horas de vida. Alma, Hector e Frieda Spelling - última mulher de Hector - entraram em contato com a obra de Zimmer, e, aparentemente a pedido de Hector, Zimmer fora convidado para conhecer o personagem que até então, para além do seu paradeiro desconhecido, parecia ser uma espécie de morto sem túmulo.

Então, a primeira arma entra em cena. Alma adentra nos aposentos de Zimmer e lhe aponta um revólver, “convidando-o” a acompanhá-la até o rancho de Hector, no Novo México. Claramente pouco confortável no manuseio da arma, Alma é rendida e tem a arma tirada. Zimmer, acreditando que arma estivesse descarregada, e numa demonstração de falsa coragem e indiferença com relação à vida, aponta o revólver para sua própria cabeça e aperta três vezes o gatilho. Por acaso, a arma estava travada, e dessa plena contingência sua vida dependeu. Um golpe de sorte, um lance de dados cujo resultado lhe foi favorável. Ainda não tinha sido sua vez de cair. 
Então, da visita tumultuada e turbulenta de Alma a Zimmer, nasce algum laço e amor entre ambos. Zimmer aceita ir até Hector. Zimmer descobre que também Alma está realizando uma espécie de obra sobre Hector, mas contando, agora, sua biografia.

Zimmer, então, narra Alma narrando Hector, que, por sua vez, narra seus filmes e suas desventuras. Hector não havia sumido de uma hora para outra em decorrência de sua morte, pelo menos não de sua morte física. Suas habilidades como galanteador lhe proporcionaram vários casos amorosos. Entre eles, Brigid O’Fallon, a repórter já mencionada antes. Porém, Hector iria se casar com uma atriz, Dolores, a qual chegou a atuar em um de seus filmes.

Os dados de Hector, no entanto, pareciam diabolicamente viciados, para sempre lhe pregando peças. Na última noite com Brigid O’Fallon, que Hector encarava como uma despedida, a pobre coitada acabou grávida. Todavia, ela só veio a descobrir de sua gravidez após ter sido internada, enlouquecida, num hospital psiquiátrico. Não suportava a ideia da separação, não aguentava o ciúme. Logo veio a tentativa de suicídio. Sabedora da notícia de sua gravidez, contudo, tentou reafirmar sua vida, e mesmo tentou procurar Hector em sua casa.

Mais um lance de azar. Hector não estava em casa, mas Brigid encontra Dolores.

Segunda arma, agora com um disparo fatal.

Dolores atinge, “involuntariamente”, Brigid no olho, ocasionando a partida desta coitada para melhor. Um novo buraco negro, agora produzido por uma bala, soma-se à série. A tragédia é acobertada, Hector protege Dolores, não conta nada à polícia, e ambos enterram Brigid numa vala fora da cidade (outro buraco, este agora na terra).

Um projétil que atravessa superfícies e mesmo estórias. Uma bala antiga. Um tiro disparado há tempos. Também sentimo-nos tentados a escutar, nesse estampido, a ressonância com outro disparo, aquele efetuado pela avó de Auster contra o seu avô, pai de Sam Auster. Uma bala que perfura narrativas e, ao fazê-lo, puxa atrás de si fios rompidos que serão novamente tecidos e emaranhados em outros textos.

Mas teria a bala encontrado o seu alvo?...

Hector, a partir desse desastre, abandona sua carreira, abandona seu percurso como ator cômico. Tira o bigode, foge para o anonimato e se afasta de Dolores. Busca a penitência e, ao mesmo tempo, a invisibilidade. Em sua fuga (para o nada), encontra numa rodoviária um boné esquecido, em cujo interior está costurado o nome de seu provável dono: Herman Loesser. Adota esse nome, como uma espécie de solução de compromisso entre livrar-se de si mesmo perante os outros, mas sem esquecer quem ele era. Herr Mann era ele mesmo. Loesser prontamente poderia soar, a diferentes ouvidos, como Lesser (menos, menor) ou Loser 
(perdedor, vencido). Para ele, essa era a roupa que lhe cabia. Claramente, a coincidência e semelhança do nome do boné, além de demonstrar o reembaralhamento das palavras e significados, também insinua uma certa dimensão onírica em jogo, algo tão conhecido pela psicanálise. Seria esse nome já o indício de que estaríamos em outro domínio, o dos sonhos?...

Hector seguia penitenciando-se, segundo Alma, e trabalhava em subempregos árduos, em tarefas braçais em que não precisava falar com ninguém, ou tinha reduzido os contatos ao mínimo. Porém, como pecador em busca de sua punição, Hector, após meses de errância, vai visitar a cidade dos pais de Brigid. E não só isso. Consegue se aproximar perigosamente da lâmina da espada ao conseguir um emprego na loja do pai da moça desaparecida (ninguém sabia que ela havia sido morta). Lá descobre que Brigid tinha uma irmã gêmea (os duplos pululam em Auster), e que não sem demora Hector ver-se-á enredado em um romance com a moça, que também cai apaixonada por ele, numa cena interpessoal de compulsão à repetição. Vivendo o terror dessa culpa e da semelhança física da irmã com Brigid, Hector afasta-se novamente.

Decaía-se mais ainda ao aceitar fazer pequenas apresentações de sexo explícito, com uma prostituta, para pequenos públicos selecionados. No entanto, Hector exigia usar uma máscara, só mostrando o seu corpo. Acrescenta mais uma camada de invisibilidade, ainda que numa aparente nudez. Torna-se, ele mesmo, uma tela branca (ou um buraco escuro) diante da qual outros projetarão suas fantasias. Um desses expectadores, e o mais assíduo, é um juiz. Mais uma vez, a extrema proximidade entre a culpa e a expiação/condenação.

Em franco desespero, Hector resolve conhecer a cidade que nunca foi sua, mas que adotara como uma de suas origens, Sandusky. Visita sua origem metafórica, e lá encontra sua imobilidade e morte irradiadas no ambiente.

A cena é assim relatada...

Um tempo frio e cinzento, uma ameaça de neve no ar e um vira-lata de três pernas como única companhia viva num raio de cem metros. ...Hector girou os calcanhares e começou a voltar. Assim que se virou, disse Alma, foi tomado por uma sensação de nulidade, um cansaço tão imenso, tão inquieto que teve de se encostar na parede de um prédio para não cair. Soprava um vento gelado vindo do lago Erie e, mesmo sentindo as lambadas no rosto, não sabia dizer se o vento era de verdade ou algo que imaginara. Não sabia em que mês estava, nem o ano. Não conseguia lembrar do próprio nome. Tijolos e paralelepípedos, o hálito condensado no ar, o cão perneta dobrando uma esquina e sumindo de vista. Era um retrato de sua própria morte, Hector perceberia mais tarde, o retrato de uma alma em ruínas, e muito depois de ter se recuperado e ido embora, uma parte dele continuou ali, parada naquela rua deserta de Sandusky, Ohio, arfando sem fôlego enquanto sua existência escapava do corpo. (Auster, 2002, p. 189). 
No Livro das ilusões, como em outras obras de Auster, há um jogo constante de projeções e antecipações, dando a entender um caráter profético de algumas situações. Muitas cenas parecem ser o presságio do que está por vir. No entanto, se olhadas por outro ângulo, a cena muda de figura e adquire novos sentidos. O penúltimo filme rodado de Hector, $\mathrm{Mr}$. Nobody, conta a estória de um executivo que, ludibriado pelo sócio, toma uma bebida, cujo efeito é torná-lo invisível, sem que ele soubesse disso. A tentativa do sócio seria apagá-lo literalmente da existência. Após os momentos de descoberta de sua invisibilidade, desespero e loucura, o personagem descobre que poderia, mesmo com sua condição invisível, atuar no mundo e exercer efeitos sobre os corpos. Após o flerte com o bem e o mal, e as inúmeras possibilidades e liberdades permitidas pela condição, o personagem de Hector elaborara sua vingança e provoca a prisão do sócio. Após reencontrar a esposa, consegue novamente voltar à condição normal. Olha-se surpreso no espelho e sente-se um homem diferente do que era, não se reconhecendo mais. Para o narrador Zimmer, o filme seria uma espécie de sombrio presságio do que estaria por vir, com Hector sumindo de cena por conta do som ter advindo ao cinema. Olhando na frente do tempo para trás, com os dados biográficos de Hector, o filme adquiria sentido, antes, como a condenação de Hector a não ser nunca mais ele mesmo, se é que ele o foi alguma vez.

Aqui vale a reflexão do filósofo Alain Badiou (2013) sobre o amor (mas que poderíamos estendê-la para outras dimensões da vida), em que do acaso de um encontro fortuito, que poderia não ter ocorrido, quando há o amor e sua aposta, uma nova ressignificação ocorre, e tudo o que tinha caráter de contingência - talvez mesmo uma vida adquire, num só movimento, uma dimensão de destino, de necessidade. Tinha que ser assim! (com todos os riscos de fechamento e estreitamento do campo dos sentidos, mesmo que um sentido seja almejado a partir dos dados aleatórios da vida).

Ora, Hector parece fazer dessa estrutura temporal de significação quase uma condenação. Hector caminha inexoravelmente em direção ao seu “destino”? Ou ele o provoca ativamente? Aqui poderíamos nos embrenhar numa reflexão sobre certa dimensão trágica, mas não o faremos. Ressaltamos, da citação anterior, da paisagem e da sensação talvez de despersonalização que ela dá a entender, uma espécie de prenúncio ou preparação do que estava por vir.

Após ter ido ao banco, presencia um assalto e, na turbulência desgovernada (ou seria governada por alguma outra instância?) do momento, Hector atira-se por sobre o corpo de uma mulher com quem, momentos antes, ele já havia flertado. Coloca-se entre ela e o tiro disparado a esmo pelo assaltante. 
Hector encontra sua bala (encontra seu destino?). Estaria Hector interceptando uma bala que talvez fosse dirigida a um outro, não à mulher ao seu lado, mas talvez a outro personagem (talvez até um “personagem” biográfico)? Estaria Auster, via Hector, tentando salvar alguém? Ou então poderia Hector estar assumindo uma culpa muito mais ancestral e que extrapola os limites desse livro? Estamos aqui, novamente, insinuando alguma proximidade entre a bala no peito de Hector e Sam Auster assistindo a morte do próprio pai com um disparo de arma. Mas também estamos insinuando que não estaria muito longe a ideia de que Hector cumpre uma pena do destino por não ter sido capaz também de salvar alguém, como o pai de Auster não foi capaz de salvar seu próprio pai, o avô de Auster.

A bala perfura seu pulmão e Hector escapa de morrer por pouco. O incidente, todavia, além de lhe ter rendido o casamento com a rica senhorita Frieda Spelling, também lhe retirou um dos pulmões. De fato, dali em diante, seu peito iria para sempre arfar em busca de ar, sempre vivendo com meia-carga de vida. O cão manco (em Auster proliferam figuras em que o corpo denuncia uma mutilação ou defeito), com dificuldade de se equilibrar sobre a terra, devolvia-lhe sua face.

Embora Frieda tivesse proferido o julgamento de que sua bala o tinha redimido de seu passado, Hector nunca cessou de buscar essa espécie de redenção.

Casa-se com Frieda, e com a herança desta, conseguem construir um rancho no qual, apesar das restrições impostas sobre si mesmo, Hector ainda assim continuaria a produzir filmes. O rancho Pedra Azul, fora construído para abrigar toda a parafernália necessária para se fazer filmes. No entanto, tais filmes não seriam visto por ninguém. Esse era o preço a pagar. E, além isso, todos os filmes realizados, após sua morte seriam queimados. Uma arte em que coincidem a produção e a destruição. E se vida e arte, em Auster, não mais se dissociam, em Hector, se ele queria salvar sua vida, teria que chegar ao ponto de também poder destruí-la, essa era sua condição irrevogável. Aqui nos deparamos novamente com os impasses da arte perante sua culpa, sua paradoxal condição de ter de dizer e, frente a dores não elaboráveis, a impossibilidade de dizer.

Essa culpabilidade quase nauseante entranhada na arte pode ser apreendida, aqui no livro, no próprio significado de Pedra Azul para Hector.

Zimmer lê nos diários de Hector (que ainda também não foram destruídos) a seguinte passagem, quase onírica, de como surgiu ao ator o nome do rancho, que merece ser citada extensamente, na íntegra: 
31/2/32. Levei o cachorro de F. para passear esta noite. Uma coisinha preta irrequieta chamada Arp. Como o artista. Dadaísta. A rua estava deserta. Névoa por toda parte, quase impossível ver aonde estava indo. Talvez um pouco de chuva também, mas com gotas tão miúdas que pareciam vapor. Uma sensação de não estar mais no chão, de estar caminhando nas nuvens. Chegamos perto de um poste e de repente tudo começou a tremeluzir, a brilhar nas trevas. Um mundo de pontos, cem milhões de pontos de luz refratada. Muito estranho, muito bonito: estátuas de névoa iluminada. Arp puxava a guia, farejando. Continuamos a andar, chegamos ao fim de um quarteirão, viramos a esquina. Outro poste e aí, ao parar um instante enquanto Arp erguia a perna, algo me chamou a atenção. Um brilho na calçada, uma explosão de luz piscando nas sombras. Tinha um tom azulado - um azul-profundo, o azul dos olhos de F. Agachei-me no chão para espiar melhor e vi que era uma pedra, talvez uma jóia. Uma pedra-da-lua, pensei, ou uma safira, ou quem sabe apenas um caco de vidro. Pequeno o suficiente para um anel, ou então um pingente caído de algum colar ou pulseira, um brinco perdido. Minha primeira reação foi dá-lo à sobrinha de F., Dorothea. [...]. Disse comigo mesmo: vou dar a pedra a Dotty. Então fui apanhá-la, mas assim que meus dedos tocaram a pedra descobri que não era o que eu imaginava. Era mole e desfez-se assim que a toquei, desintegrando-se numa gosma escorregadia e molhada. Aquilo que eu tomara por uma pedra era um papelote de cuspe humano. Alguém passara por ali, esvaziara a boca na calçada e a saliva se juntara numa bola acetinada, numa esfera multifacetada de bolhas. Com a luz passando por ela, e com os reflexos da luz dando-lhe aquele tom lustroso de azul, tinha me parecido um objeto sólido e duro. Assim que percebi o erro, retirei a mão como se a tivesse queimado. Senti ânsia de vômito, tomado de nojo. Meus dedos estavam cobertos de saliva. Não tão ruim quando é a da gente, talvez, mas nojenta quando vem da boca de um estranho. (Auster, 2002, pp. 280281, itálicos no original).

Notemos a conjunção entre o onírico - quase com ares de uma experiência estética sublime - e o abjeto. Pedra Azul seria o nome do rancho onde se produziriam filmes (sonhos) que eram apenas um engodo, uma arte condenada de antemão pela culpa, e uma culpa que não larga. Uma arte viscosa. Essa viscosidade, que gruda nos dedos de quem entra em contato com o objeto aderente, é o que fará com que, de alguma forma, apesar do anseio de Hector de apagar todos os traços de sua vida, ainda assim algo fique impregnado. Vive-se aí uma dupla e paradoxal condição: um testemunho impossível, pois a arte destruída deixa um vazio, mas ainda assim algo permanece impregnado na pele daqueles que foram tocados, ocasionando a transmissão de uma herança, de um segredo... e que de alguma forma será testemunhado também.

Zimmer conhece finalmente Hector, já velho e acamado. Um profundo estranhamento lhe toma o espírito, pois aquele que ele conhecia apenas como uma figura espectral ganhara, de repente, um corpo, uma materialidade, mesmo que também decaída (próxima à morte). Porém, também esse pequeno corpo logo desaparecerá. Hector morre na mesma noite que 
Zimmer chega à sua casa, poucas horas depois do encontro e das poucas palavras trocadas (e não sabemos ao certo se algo ou Frieda ajudou a acelerar o caminhar ao mundo de Hades).

Como era desejo de Hector, seus filmes seriam queimados após seu enterro. Frieda, num acesso furioso e impetuoso, acelera o processo. Restava pouco tempo para assistir a alguma coisa feita por Hector no rancho Pedra Azul. Zimmer e Alma assistem, juntos, $A$ vida interna de Martin Frost, uma espécie de comentário e prefiguração da própria cena de morte da Hector e a queima de seus arquivos. No filme, Martin Frost (esse outro sujeito congelado), é convidado pelo próprio Hector (personagem que vira personagem, em abismo) a passar uma temporada na fazenda, agora denominada Terra do Sonho. Ele é um escritor que passará algum tempo ali, em descanso, para redigir um conto. Depara-se, na casa, com Claire, uma jovem estudante de filosofia. Estranha a presença não anunciada dela. Das discussões iniciais, o caso se transforma num romance. Passam algumas semanas juntos, e à medida que Martin vai concluindo seu conto, Claire cai doente, cada vez mais enferma. Em certo ponto, Martin apercebe-se que Claire não existe, que é apenas sua musa inspiradora. Em desespero, conforme as páginas chegam ao final, e Martin vê Claire não sair do estado febril, o escritor abandona o conto e queima as páginas, numa tentativa bem-sucedida de ressuscitar a companheira de fantasia. O filme revela os impasses de um luto nunca bem realizado e os perigos de um enclausuramento imobilizante no "quarto", nos aposentos do escritor.

A última tomada do filme passa da cena de Martin e Claire novamente abraçados para a paisagem estagnada da fazenda. É estagnação do tempo do trauma. "Está tudo parado. Não há vento; os galhos estão imóveis; nem uma única folha se mexe. Passam-se dez segundos, depois quinze e então, repentinamente, a tela fica escura e o filme acaba.” (Ibid., p. 263).

Antes de também nós concluirmos, em estagnação, o texto, chegando ao final do livro e de sua última cena trágica, é importante pincelar algo sobre Alma.

De maneira análoga ao feminino como figura da alteridade - na leitura de Lévinas (1961) em Totalidade e Infinito -, em seus passos silenciosos pela casa, Alma condensa e reverbera uma multiplicidade de sentidos possíveis no livro e na obra de Auster.

Algumas considerações...

Antes de mais nada, a figura feminina comparece mais intensamente do que no livro anteriormente comentado ( $A$ invenção da solidão). Essa visitação tardia do feminino, e notadamente do feminino como elemento de alguma redenção, elaboração ou mesmo cura, parece ter uma recorrência estrutural em Auster. É interessante notar, contudo, que os nomes do feminino sempre insinuarão alguma dimensão de alteridade para os personagens de Auster, ou mesmo de alguma promessa de algum restabelecimento das subjetividades fraturadas. 
Como exemplo, no livro A noite do oráculo (2003), a personagem Grace (e não somente seu nome, mas também a trama que a envolve) remete claramente à figura da graça (e a graça sempre tem algo da ordem da visitação). Alma, por sua vez, remete a certa dimensão espiritual (evidentemente, o nome em espanhol esconde, em relação ao inglês, certa reserva de sentido, não sendo explícito seu significado como em português ou espanhol), e sua presença na vida de Zimmer o desperta de um sono profundo.

No livro, Alma carrega no rosto uma marca de nascença, uma mancha escura na bochecha do tamanho de um punho de um homem. Ela traz em si, em alguma medida, as marcas de beleza da imperfeição humana. Tal marca, por outro lado, também lhe servia como instrumento, durante sua vida, para ler e conhecer as pessoas com quem se deparava, fundamentalmente a partir das reações das mesmas a essa mancha em sua pele. Alma torna-se uma exegeta da alma dos outros. Ao mesmo tempo, os homens, e mesmo Zimmer, têm dificuldade em apreendê-la em seu caráter único. Outra imagem interessante, entre muitas, é o fato de que Auster deixa em aberto, sujeito a ambiguidades e a certa desconfiança, o estatuto de realidade de Alma no livro. Por vezes, Alma parece ser também, como Claire para Martin Frost, uma espécie de idealização, com toda a violência implicada na redução do feminino aos “punhos de um homem”, que também poderia significar, por outro lado, a clara e confessa presença da mão do escritor (os punhos) no rosto dos seus personagens. A autonomia dos personagens em relação ao autor, ou mesmo antes, a autonomia da arte em relação à vida nunca seria total. Há, sem dúvida, também, uma silenciosa crítica a certo falocentrismo, e Auster parece brincar e ludibriar também os leitores, ao desenhar personagens masculinos que se assemelham ao sujeito apaixonado do amor cortês e romântico, fazendo-nos desconfiar da ingenuidade e distorção desses amantes.

No entanto, a graciosidade teve um papel fundamental na vida e mesmo na continuidade da obra de Auster. E talvez ela compareça, em Auster, como uma das figuras do feminino. Em sua vida, tal estado de espírito se deu após ele ter assistido a um ensaio de um espetáculo de dança (retornamos à coreografia dos corpos). O efeito, sobre ele e sobre sua escrita, foi expressivo, levando-o a retomar o trabalho com a prosa, e não só com a poesia.

... em dezembro de 1978, fui por acaso a um ensaio aberto de um balé coreografado pelo amigo de um amigo e algo aconteceu comigo. Uma revelação, uma epifania - não sei como chamá-lo. Algo aconteceu e todo um mundo de possibilidades de repente se abriu para mim. Acho que foi a absoluta fluidez do que estava vendo, o movimento contínuo dos dançarinos ao se moverem sobre o chão. O espetáculo me inundou de uma imensa felicidade. O simples fato de observar homens e mulheres se movendo através do espaço me inundou de algo próximo da euforia. Logo no dia 
seguinte, sentei-me à escrivaninha e comecei a escrever Espaços brancos, uma pequena obra de nenhum gênero identificável - que foi uma tentativa da minha parte de traduzir em palavras a experiência daquele espetáculo de dança. Foi uma libertação para mim, um tremendo alívio e vejo esse trabalho agora como a ponte entre escrever poesia e escrever prosa. Foi ele que me convenceu de que eu ainda era um escritor. Mas tudo seria diferente agora. Um período totalmente novo em minha vida estava prestes a começar. [...] É muito estranho, mas lembro que terminei esse trabalho a 14 de janeiro. Fui dormir altas horas da noite, entre duas e três da madrugada. Às oito da manhã, o telefone tocou e um de meus tios do outro lado da linha me contou que meu pai morrera durante a noite... (Auster, 1992, pp. 275-276).

A dança, em sua leveza, suspensão e fluidez, desafiando a gravidade e sendo mesmo uma espécie de resistência à queda dos corpos, produziu em Auster uma liberação da escrita. O próprio Auster descrevia seus primeiros poemas como sendo uma espécie de "punhos fechados” (os mesmos punhos, enquanto marca, no rosto de Alma?), e a dança ajudou a abrir a mão do escritor. A invenção da solidão veio depois de Espaços brancos, e de fato parece portar as marcas dessa liberação. A morte do pai também se faz presente nessa cena, compondo esse quadro de dança, graça, morte, herança, dívida, culpa e escrita.

Ajudemos Auster a ver esse efeito da dança e da graciosidade sobre sua alma. Podemos trazer o crítico alemão Hans Ulrich Gumbrecht (2012), com seu livro de ensaios Graciosidade e estagnação, para nos fornecer brevemente (tão breve como os estados de graça, quase no intervalo de um piscar de olhos) algumas imagens sobre essa questão.

Gumbrecht, como já havíamos feito brevemente antes com auxílio de Caruth e Paul de Man, retoma Kleist e seu Teatro de marionetes. Em relação a este livro de Kleist, Gumbrecht comenta os estados de suspensão e leveza que a dança das marionetes enseja (e elas dançam!). Os bonecos se mostram, em grande medida, graciosos (e têm graça) porque não revelam nenhuma intenção, suas ações são mecânicas (como havíamos trazido no texto anterior, quanto mais “mortos”, passíveis e dóceis, mais livres para voar e flutuar). De maneira muito próxima aos atores cômicos do cinema mudo, ou dos distraídos, o efeito da graça será tanto maior quanto menor a consciência daquele que assim age. Embora Kleist assim não o faça, seu texto, como Gumbrecht deixa claro, resvala para certa teologização, com as imagens de elevação e queda. A queda do homem em pecado. A subida aos céus dos justos, ou os estados de elevação nos êxtases religiosos. Não por acaso, como o crítico literário aponta, a expressão latina para graciosidade - gratia - também pode significar “misericórdia”, adicionando mais um ingrediente para nosso caldeirão místico e religioso. E talvez os personagens de Auster estejam ao encalço disso! 
Outra ressonância e presença importante para nós aqui, levantada por Gumbrecht, é a referência a Heidegger, e sua compreensão da graciosidade na chave do "autodesvelamento do Ser”. Em momentos curtos, fugidios e raros, todos nós podemos ser tomados por um objeto ou mesmo entramos numa espécie de conexão profunda e direta com as coisas do mundo. O Ser, nesse estado de graciosidade fugidia, entretanto, mostra-se para logo em seguida se retirar, em silêncio.

E Alma se retira...

Ou melhor, talvez poderíamos dizer que é sacrificada no livro, nas penas de Auster.

Ao ter seu trabalho de pesquisa biográfica sobre Hector queimado (a senhora Frieda Spellman traz também algo da loucura da avó de Auster nesse momento), Alma entra numa briga corporal com Frieda e, “involuntariamente”, a lança ao chão. Alma sai do quarto indignada e exasperada, e não chega a notar que Frieda batera a cabeça no chão. Um lance do acaso? O fato é que Alma não suporta a culpa da tragédia. Assim como Hector, buscará sua penitência e abandonará a vida no seu último ato.

Alma enfim pode chegar mais perto do que ninguém para testemunhar Hector. $\mathrm{Na}$ verdade, depois de certo limiar, o testemunho torna-se impossível, e já não haveria retorno daí, como Giorgio Agambem (2008) comenta acerca daqueles olharam de frente a morte, ou os que viram perto demais a dor indizível, os musselman dos campos de concentração, aqueles que, ainda que fisicamente vivos, não retornaram mais para falar. Alma herda o segredo de Hector, identifica-se com ele e também apagará seus traços da existência.

E quanto a Zimmer?... Bem, o livro de Zimmer e a história de Hector nos chegaram, ainda que, assim como Chateubriand ${ }^{17}$, esse livro também seja uma memória do além-túmulo, pois Zimmer só autorizou a publicação póstuma.

Nesse caminhar, dos desequilíbrios da existência à visitação da graça, e seu posterior recolhimento, somos deixados com os rastros de um testemunho incerto... sempre às bordas da ilusão e da mentira.

\footnotetext{
${ }^{17}$ Zimmer ocupou-se da tradução das memórias de Chateaubriand, que escreveu seu livro enquanto estava vivo, só permitindo a publicação após sua morte. "Memórias de um morto” é a forçosa tradução de Zimmer para Mémoires d'outre-tombe (Memórias de além-túmulo).
} 


\section{A escrita da cripta}

... a vida começa menos lançando-se para a frente do que girando sobre si mesma.

Gaston Bachelard - A poética do espaço.

A ficção dá olhos para o narrador horrorizado. Olhos para ver e para chorar.

Paul Ricoeur - Tempo e Narrativa.

Que os começos, em um texto literário, guardem algo de uma abertura de mundo pode ser aprendido quando nos deparamos com "manuais” que ensinam a como ler atentamente um livro (ou um poema) em seus diversos níveis. Entre esses, o do Terry Eagleton (2013), How to read literature, nos fala desses começos. O crítico literário inglês, como fazem outros autores em demais livros do gênero, realiza um detido comentário acerca das nuances presentes logo quando a partida começa, quando lemos as primeiras frases de um texto.

Se é verdade que nunca nos aproximamos de um texto de maneira ingênua, sem algum horizonte de expectativas, e que isso modela em alguma medida nossa apreensão dele, também é certo que o próprio texto deve nos frustrar ou nos abrir possibilidades inauditas, e isso logo em sua abertura. O autor faz sua aposta nos começos: está em jogo, aí, sua capacidade de cativar o leitor, seja em qual dimensão isso for ocorrer. Porém, para além de sua sedução, ou justamente por causa dela (e pela série de artifícios da linguagem e pela capacidade de expressão que o autor emprega), a abertura em um texto literário também inaugura um mundo, e, talvez, um mundo que não existia até então, mesmo que, como com nosso autor - Paul Auster -, a impressão possa ser de uma reedição constante. Mundos que não existiam antes, mas inaugurados por uma potência criativa, mesmo que criados a partir das torções a que se dá na e pela linguagem, isso seria o que de mais próximo teríamos da criação divina, Eagleton brinca (2013, p.8).

De fato, essa criação inaudita, ex-nihilo, como que vinda do nada e que nos cai à cabeça, para usarmos as imagens que Derrida (1999) emprega em Dar la muerte, denota um encontro com algo que não sabemos ainda o que é, suspenso entre o lançamento e sua queda, tal qual um meteoro que invade a Terra. Essa suspensão, que é uma indecisão também, não permite dizer a priori do que se trata quando nos deparamos como uma frase como a que Derrida utiliza logo no começo de seu livro acima mencionado: "Perdão por não querer dizer...”. 
Perdão por não querer dizer o que? E a quem? De quem para quem? E essa frase é literatura? E o que ela quer dizer?...

Se um texto literário inaugura um mundo, vindo de um além ou aquém e se inserindo em uma fenomenalidade, ou mesmo abrindo um espaço para a aparição de outros entes (algo próximo da doação do Ser no sentido heideggeriano), isso não exclui, contudo, o fato de que a literatura também porte segredos (e dos mais diversos). Ela carrega e insinua, com seus traços, ausências daquilo que talvez nunca saibamos o que é, que se recolhe em velamento ou então nunca se mostra (e o desvelar disso, como se pode depreender de Heidegger, talvez produza alguma violência). Mesmo em seus inícios, em suas aberturas fenomenais que funcionam como instauração de mundos, para insistirmos nesse vocabulário heideggeriano, a literatura diz tanta coisa quanto esconde.

Em Paul Auster, com seus (re)começos literários, nos deparamos quase sempre com aberturas que, ao montarem o tabuleiro de onde se dará o jogo, acabam "mostrando" - em segredo - tanto as peças que fazem parte do cenário quanto aquelas que estão ausentes, ou mesmo aquelas que talvez nunca estiveram alguma vez presentes, mas que ainda assim continuam a sussurrar e a influir no jogo, até ao ponto de derrubar o tabuleiro e as peças visíveis. Peças e dimensões fantasmas que, de outro mundo, de outra dimensão, apesar de convidarem e incitarem ao jogo, também põem em xeque a própria existência dele.

Nos dois ensaios anteriores, mostramos como os personagens, ou Auster (já que podemos entendê-lo como um personagem que ficcionaliza a si mesmo no que viria a ser uma autobiografia, sua obra $A$ invenção da solidão), estão à caça de algum desaparecido, de um ausente. Personagens capturados por um luto e enfeitiçados pelo rastro de alguém que já não mais está aí (ou nunca esteve). Esses ausentes, por sua vez, origem e sentido da atividade detetivesca da série de personagens de Auster, olham os personagens e os miram, mas o fazem por detrás de suas viseiras e elmos, o que não permite enxergar quem está aí. Olham sem ser vistos, como nos diz Derrida (1993) em Espectros de Marx. E olham a partir de outro mundo. Convocação do além, do além-túmulo às vezes, mas cuja força interpelante se faz sentir, obrigando a um trabalho árduo de resposta, memória e, talvez, recriação, seja para nomear os demônios, seja para exorcizá-los (ou talvez os dois, como reza a liturgia do exorcismo, um se dando junto com o outro).

Mas, em a Noite do Oráculo, o livro que acompanharemos aqui nesse ensaio, o desaparecido é o próprio narrador, ou então o que ele fora até então, como se ele fosse um sobrevivente à própria morte que não veio e vivesse uma espécie de vida póstuma, mas ainda em vida. Torções e volteios da vida e da morte, numa dança em descompasso. 
Estive doente durante muito tempo. Quando chegou o dia de deixar o hospital, eu mal sabia andar mais, mal conseguia lembrar quem era. Faça um esforço, disse o médico, e dentro de três ou quatro meses vai estar recuperando o ritmo das coisas. Não acreditei nele, mas segui seu conselho mesmo assim. Tinham me dado por morto, e, agora que havia frustrado suas previsões e misteriosamente sobrevivido, que escolha me restava senão viver como se houvesse uma vida futura à minha espera? (Auster, 2003, p. 7).

Se já é difícil enlutar um ente que se foi, como fazê-lo quando o morto é o próprio vivo que teima em viver, contra todas as previsões e expectativas? Como é sobreviver à própria morte, mas do lado de cá, na morada entre os mortais, perante os deuses, embaixo das estrelas e sobre a terra? Carregar o morto que se é, ser um túmulo para aquele que, apesar de ter vivido uma interrupção da continuidade do existir, ainda sobrevive. Aqui, para esse Lázaro, tanto a vida quanto a morte se tornam espectrais.

Lembremos, a título de comunicação entre mortos-vivos, de Maurice Blanchot e a descrição literária que fez do instante de sua morte (que não adveio). Blanchot (1994) narra (nos mesmos moldes que Auster também já o fez: em terceira pessoa) sua detenção por tropas nazistas e sua conseguinte (quase) execução num fuzilamento. Por um instante, mas cujo intervalo durou (e um instante que dura num intervalo pode se aproximar do problema da quadratura do círculo) toda a sua vida, a morte certa que se anunciara não veio, e o pelotão debandara com a chegada do exército inimigo. Aqui, o desastre se dá não pela morte, mas por sua não chegada, e esse tema assombrará Blanchot e lhe fará meditar sobre a "a literatura e o direito à morte” em alguns outros momentos de sua obra. Algo, no entanto, se rompe quando a morte visita, mas vai embora, sem levar seu objeto de busca. As coordenadas e pilares da terra, da realidade e do eu são abalados e exigem reconstituição, como em todas as situações traumáticas e catastróficas. Essa reconstituição só poderá se realizar, em muitos casos, pela via ficcional.

Sidney Orr, nas palavras de Boulter (2011), está em luto por uma “ontologia perdida” (p. 36). O narrador não revela a doença que o levou a ser internado, salvo esses sintomas tão nebulosos quanto sua própria existência. Ele não morreu, mas se sente como um fantasma, ou como um espectador no sonho de outra pessoa. Sentindo-se fora de si mesmo, em estranhamento e alienação, há essa perspectiva de um intervalo existencial, que em Invenção da Solidão Auster nomeara como uma "nostalgia pelo presente”.

Com pernas arrastadas e cansadas, Sidney Orr sai do hospital no qual esteve internado (não sabemos ainda quanto tempo) para tentar vir a habitar novamente o mundo dos vivos, 
mas ainda sem conseguir fazer esse encaixe. Seu estado anterior, ou quem ele fora até então, é segredo para o leitor.

Mas sigamos com ele nessa busca (que, com outros personagens de Auster, fora malograda, mas que apostamos que dessa vez não o seja) pelo seu próprio desaparecimento. O desastre já ocorreu, mas não sabemos se se refere somente à sua estadia no hospital por doença ou se Orr tocou em algo ainda mais mortífero.

Orr sente-se um velho, ainda um doente, e o peso da gravidade de sua situação se faz sentir pelo passo arrastado e por uma sabedoria misteriosa, uma sabedoria de morte.

Ao olhar para o mundo, não consegue discernir seus contornos claros. Objetos e pessoas se misturam e perdem nitidez; seu próprio corpo perde os limites até então conhecidos e seu perímetro fica borrado com o do mundo.

O mundo saltava, boiava na frente dos meus olhos, ondulando como reflexos em um espelho irregular, e sempre que eu tentava olhar uma coisa só, isolar um objeto único do fluxo de cores em torvelinho - uma echarpe azul em volta da cabeça de uma mulher, digamos, ou a luz vermelha da traseira de um caminhão de entrega -, a coisa imediatamente começava a se separar e dissolver, desaparecendo como uma gota de tinta em copo de água. (Auster, 2003, p.8)

Aqui, o mundo é visto com contornos incertos, aquosos, que se dissolvem como a tinta na água. O mundo se dilui sob essa vista talvez lacrimejante, mas não ciente do que chora, ou se chora afinal.

Sidney Orr $^{18}$ tenta voltar à vida. Porém, tenta voltar quase em fingimento, como se ainda existisse um porvir, um futuro que esperasse por ele.

Ele data o dia em que tudo começou (e vamos supor, com ele, que algo alguma vez começou; isso não é certo). A manhã em questão é 18 de setembro de 1982. Saiu de casa para caminhar e, por acaso, após virar numa esquina, na Court Street ${ }^{19}$, que geralmente não fazia parte do itinerário de caminhadas, encontra a papelaria de M.R. Chang ${ }^{20}$. Entra na loja e o que

\footnotetext{
${ }^{18}$ Orr é a abreviação de Orlovsky, sobrenome dos avós judeus emigrados, que, para facilitarem a assimilação cultura, o abreviaram para Orr, soando, assim, mais americano. A herança e errância judaica se escondem por detrás de Orr (um sepultamento?).

${ }^{19}$ A rua de corte, local da lei e dos soberanos que legislam. Derrida (2001), em Mal de arquivo, nos lembra dessa arkhê, local de comando e de começo, de lei e de memória. No arkheîon, casa dos magistrados, as leis são reunidas, consignadas e guardadas, para os arcontes as interpretarem. A cena de julgamento e do arquivo, do processo de arquivar, encontramo-las em toda esquina em nosso livro.

${ }^{20}$ Na verdade, Orr confunde o M.R. no cartão que Chang lhe deu, lendo-o como "Mister”. Chang, por sua vez, também confunde o nome de Orr (ouvindo-o como or [ou, em inglês]). Orr não sabe como entender o M.R.: “Mentalidade Rica. Misteriosas Revelações”. Ainda que tenhamos usado a tradução em português, esta secreta bem nossas apreensões oraculares quanto aos personagens.
} 
percebe, como primeiro impacto, quase abafado, é o silêncio do local, e, em seguida, por conta do mesmo silêncio, escuta o som da lapiseira do comerciante.

Agora, toda vez que penso naquela manhã, o som daquela lapiseira é sempre a primeira coisa que me volta. Na medida em que a história que vou contar faça algum sentido, acredito que foi aí que começou - no espaço daqueles poucos segundos, quando o som daquela lapiseira era o único som que restava no mundo (Auster, 2003.p.8).

Se lhe dermos nosso voto de confiança, então podemos aceitar que algo da ordem de uma reconvocação ocorreu nesse instante, no roçar do grafite sobre o papel, como se fosse um chamado, um murmúrio que sussurrasse algo para Orr. Mais uma vez, algo excita - convoca para fora - os personagens de Auster. A vida (e uma vida pela escrita) risca seu traçado novamente, talvez como nas ondas gráficas de um medidor cardíaco, que, voltando a oscilar, indica que a linha reta da morte ainda não chegou, ou então que se desfez. Uma linha reta sobre a qual o traçado caligráfico do escritor assinará seu idioma (seu estilo): o encontro das linhas horizontais dos cadernos (linha reta da morte) com o instrumento pontiagudo que é o lápis ou a caneta (que, ao incidir transversalmente, faz pulsar) ${ }^{21}$.

Da sensorialidade do som da lapiseira ao simbolismo da escrita como alguma fonte de vida, Orr empreende seu salto (não sabemos se um voo ou um mergulho. Talvez os dois, como que a indicar a suspensão de um existir indeciso...). Sente-se fortemente atraído por um caderno de capa azul, aveludado e de origem portuguesa. É o seu caderno-mágico. A vontade de escrever retorna com força (e ficamos sabendo que Orr trabalha como editor de livros, mas também é escritor).

Mas sem ainda saltarmos à frente (estamos somente no começo, com seus segredos pesados que nos puxam para baixo), Orr, na primeira da série de suas notas de rodapé, começa a interromper a linearidade de seu relato para nos situar no tempo ${ }^{22}$. O que ele escreve é sobre eventos que aconteceram há vinte anos atrás, do que se presume que estamos em 2002 (por coincidência, um ano após o ataque das Torres Gêmeas nos EUA). Se, há vinte anos, o

\footnotetext{
${ }^{21}$ Paul Auster redige seus livros em cadernos. Algumas das edições em português trazem, na capa, imagens de seus cadernos escritos. Na capa de Noite do Oráculo está impresso uma das páginas de seus cadernos, com sua escrita cheia de rasuras, como que revestindo o livro numa espécie de pele caligráfica-estética. Dependendo da posição que adotamos para deixar nossa imaginação olhar o livro, se de fora para dentro ou se de dentro para fora, teremos que a escrita na capa ora convida ao mergulho, ora salta para fora, transbordando. Na capa editada, num interessante jogo de espelhos, o que é original e o que é cópia torna-se problemático.

${ }^{22}$ As notas de rodapé, em Noite do Oráculo, funcionam, entre outras coisas, como uma espécie de registro histórico, servindo, entre outras coisas, para contextualizar a vida dos personagens e para inserir fragmentos de acontecimentos que circundam a vida dos protagonistas, como, por exemplo, eventos históricos como a Revolução Cultural Chinesa, o Holocausto ou cenas trágicas de violência da vida urbana.
} 
personagem vivia um luto por essa espécie de ontologia perdida, então esse luto ainda não foi elaborado, mesmo após esses anos. Ou então, talvez o processo desse luto só possa estar sendo narrado agora, após todo esse tempo. Seja como for, insinua-se que há uma ação (narrar os eventos de 1982) que ocorre muito tempo depois, uma ação diferida, desviada para o futuro (que é o presente da narrativa) por alguma razão, pela força gravitacional de uma matéria escura desconhecida.

Esse uso de desvios bem como a elaboração de enredos que desmontam a linearidade temporal da narrativa são muito utilizados, conforme nos aponta Luckhurst (2008), por narrativas do trauma que se dobram a um imperativo de inscrever, em sua dimensão mais formal (e não somente no plano do conteúdo), algo desse descarrilamento da experiência que os eventos traumáticos suscitam. Em Noite do Oráculo, tais descarrilamentos vão dando suas caras, gerando experiências de distensão do tempo, regressão e visitação do passado no futuro e do futuro no passado. De onde falam os personagens? De qual tempo?... Aqui, o leitor fica cego, e seu único recurso é talvez aceitar o jogo do autor (ou do narrador) e se entregar ao texto, fazendo deste o pedaço de papel-tecido que vendará seus olhos. Não só Sidney Orr enxerga mal, também o leitor aceita ficar cego temporariamente, confiando que o livro poderá guiá-lo por caminhos escuros.

Das belas imagens que Derrida nos conta em seu livro Memórias de cegos: autoretrato e outras ruínas para falar dos desenhos de cego como metáforas do escritor, podemos selecionar essa ideia do cego que vive entre a antecipação e precipitação. Antecipa-se para não se precipitar, não cair.

... a escrita entrega-se antes à antecipação. Antecipar é tomar a dianteira, tomar (capere) antecipadamente (ante). Diferentemente da precipitação, que expõe a cabeça (praecaput), que se atira de cabeça, de cabeça no ar, a antecipação seria antes coisas da mão. O tema do desenho de cego é antes mais a mão. Esta aventura-se, precipata-se, é certo, mas desta vez nas vezes da cabeça como que para a preceder, prevenir e proteger. Parapeito. A antecipação protege da precipitação, adianta-se ao espaço para ser a primeira a agarrar, para se lançar para diante no movimento da preensão, do contato ou da apreensão: de pé, um cego explora às apalpadelas a extensão que deve reconhecer sem ainda a conhecer - e o que na verdade ele apreende é o precipício, a queda - e ter já franqueada alguma linha fatal, com a mão desprotegida ou armada (a unha, a bengala ou o lápis). (Derrida, 1991, p. 12; itálicos no original).

Com seu cajado, seu braço ou seu lápis, o escritor (como o leitor também) é um cego. Tateia no escuro, e o que ele apreende é a possibilidade do abismo. Antecipa-se, põe-se à 
frente de si mesmo com sua caneta-cajado para, num só risco, vasculhar a noite da existência e desenhar os contornos de sua própria obra ${ }^{23}$.

Se Orr fracassou em morrer, tentará, apesar ou por causa disso, vingar a vida. A escrita é seu cajado na viagem, em autoexílio, para o deserto que é o livro.

Sua esposa, Grace ${ }^{24}$, de quem sabemos um pouco em uma das notas de rodapé, é mais uma das figuras do feminino que remetem a motivos teológicos em Auster. Sindey Orr conhecera Grace na editora onda trabalha e o encantamento por ela se deu pelo que, nela, estaria para além da simples e evidente beleza. Havia, nela, algo de uma despreocupação com o que os outros iriam pensar dela, uma espécie sua inocência cega (quase uma redundância), relaxada. Orr admira o que, nela, não é peso, mas leveza. Não o ruído de uma pessoa carregada de conflitos, mas o silêncio de alguém que possui, em suas palavras, a "alma velha”.

... foi por isso que me apaixonei: pela sensação de calma que a envolvia, o silêncio radiante que queimava ali dentro. (Auster, 2003, p. 24).

A graciosidade e a leveza do silêncio, de uma quietude interna. Beatitude.

Orr tenta descrever, por uma via negativa (isto é, vai eliminando os predicados mais visíveis para tentar alcançar um núcleo inefável), o que Grace é para ele, o que ela traz que o visita e toca, o faz ficar apaixonado, mas tudo que elenca ele abandona por ser insuficiente, por não conseguir conter e dizer a faísca que emana do ser daquela que o incendiou. Há, claramente, uma certa retórica do amor cortês, com sua versão de uma donna angelicata. Esse vocabulário quase romântico, embora aponte para alguma dimensão do sublime representado por Grace, também tem o efeito (já que é um romantismo com um tom muito autocrítico, uma versão pós-moderna desse amor cortês) de realçar os limites da descrição do escritor e de sua compreensão da alteridade do feminino, ou, se seguirmos Lévinas ${ }^{25}$, do feminino como alteridade. Os passos silenciosos (leves) de Grace visitam os aposentos de Orr, mas o narrador (como veremos depois) por vezes não nota sua presença (como não é notado pela esposa). Se o feminino enquanto fonte de alteridade, que incita o desejo e a carícia - imagem levinasiana para falar dessa intencionalidade do homem em direção ao feminino enquanto futuro -, está

\footnotetext{
${ }^{23}$ Um escritor que sabe, de antemão, aonde sua caneta o levará, a partir de um programa sistemático de criação, talvez seja um burocrata literário. Aquele que não atravessa a escuridão talvez não consiga trazer dela nada luminoso. A escrita é uma sonda no escuro.

${ }^{24}$ Comentamos, no ensaio anterior, sobre algumas imagens da graciosidade que esta personagem faz pensar e que se articula com outros personagens e momentos da obra de Auster.

${ }^{25}$ Essa descrição da alteridade do feminino pode ser encontrada em Totalidade e infinito, de Lévinas (1961), bem como na releitura de Derrida (2004) desse texto, em Adeus a Emmanuel Lévinas.
} 
subentendido na poetização de Orr em relação a Grace, também se faz notar uma crítica do gesto fracassado de apreensão do feminino por parte do escritor. Essa lacuna, abismo intransponível, será fonte de vacilações e de tentativas de se apoderar narrativamente do seu objeto, disseminando uma leitura sempre suspeita e aprisionante, que confluirá com o destino da estória. O feminino, fonte de beatitude e origem da carícia, talvez fale coisas - do modo de ser e da expressividade do corpo de Grace às palavras que profere - que nosso narrador não entende, como uma divindade cuja mensagem precisa ser o tempo todo interpretada, mas sempre correndo o risco de ser uma interpretação fracassada.

Assim, o livro e o amor caminhos juntos, muito embora possam, eventualmente, soltar as mãos.

Mas o que escrever em seu caderno? De onde tirar uma ideia? A ajuda vem de John Trause $^{26}$, antigo amigo da família de Grace, e que a conhece desde pequena. Trause, mais velho que o casal (e essa dimensão do que é mais antigo e idealizado sempre remeterá à sombra da figura paterna em Auster), é um escritor renomado, mas cuja obra se interrompeu há sete anos. A posição subjetiva do narrador, em Noite do oráculo, se expande paulatinamente conforme o texto avança, assim como, simultaneamente e na mesma proporção, a dúvida do leitor acerca da confiabilidade desse narrador. Orr idealiza seus objetos de afeto - Trause e Grace -, mas sente ciúmes no que eles trazem de mistérios e segredos Assim, a adoção do ponto de vista de Orr irá, com o tempo, nos levar a estreitamentos e incertezas, mas deixemos isso em suspenso também.

Trause casou-se duas vezes. Com sua primeira esposa, tivera Jacob, seu único filho. Tina Ostrow, sua segunda esposa, era uma bailarina-coreógrafa mais nova que ele, e desde sua morte, de câncer no útero, Trause não entrega ao mundo nenhuma obra. A ligação com a obra enquanto futuro e a possibilidade da herança intergeracional ficam congeladas, o que é reforçado pelo fato de que Trause, em grande medida, renega afetivamente o filho, Jacob ${ }^{27}$.

Um luto talvez interrompido faz sua aparição, ou melhor, já que o trabalho psíquico de luto, por sua própria natureza, atua em segredo e por detrás da fenomenalidade, estaríamos às voltas com os efeitos desse luto, nunca com o próprio. À dimensão antifenomênica do luto, além disso, é preciso acrescentar a dimensão de antitrabalho: o que entrava o luto e o deixa

\footnotetext{
${ }^{26}$ Trause é o anagrama de Auster, o que nos faz pensar da sombra do autor sendo inscrita, de maneira encriptada, no texto. Como veremos ao longo do ensaio, os duplos se multiplicam no enredo.

${ }^{27} \mathrm{E}$ as personagens bíblicas assombram, aqui numa clara referência a Jacó e Esaú. Como veremos, Esaú, nesse livro, estaria representado tanto por Orr e como também por Grace, da qual Jacob sente, compreensivelmente, um ciúme mortífero e assassino. As promessas da herança são, metaforicamente, dirigidas ao casal Orr-Grace, que são os herdeiros do amor e afeto de Trause. Jacob fracassa em enganar o pai, o cego Trause-Isaac, que nunca abandonou a cegueira-invisibilidade em relação ao filho. Nesse labirinto de espelhos, vamos notando o comparecimento de muitos cegos e de muitos pais, inclusive o próprio pai de Auster.
} 
em estado suspenso, emperrando seu trabalho (a inveja, a mania, o triunfo, a ambivalência em relação ao objeto perdido etc.). Por outro lado, talvez seja próprio do luto que ele nunca seja completamente realizado, que ele sempre deixe, atrás de si, ruínas intocadas. O processo de restauração narcísica, após perdas e traumas, nunca é totalizante. Sempre há escombros e entulhos sob os quais os enlutados reencontram e abraçam seus objetos (nunca) perdidos, formando um rastro histórico, em cadeia, de traumas arquivados. Como uma condição muito mais frequente que a melancolia clássica, Figueiredo (2014) nomeia de luto encruado a condição de um luto interrompido que fica a meio caminho entra a melancolia e a superação da perda (via desligamento e posterior reinvestimento libidinal em outros objetos). Mas, novamente, poderíamos suspeitar, junto com Derrida (2001a), que nunca um luto seja completamente bem-sucedido, ou pelo menos não deveria sê-lo, por respeito e mesmo fidelidade (em algum nível, melancólica) ao outro, mesmo que ao outro-em-mim, nessa espécie de fora-dentro em que o mais exterior faz abrigo no mais interior.

Quando a perda (e o trauma, já que sempre há um componente traumático nas perdas) é excessivamente intolerável, a defesa frente a isso exige do ego mecanismos mais incisivos e massivos, o que é notado com mais força em condições em que essa condição não somente diz respeito à partida de um objeto externo, mas também, e simultaneamente, quando esta perda atinge e rasga o self em seus níveis mais arcaicos e narcísicos. Ou seja, quando a perda é a de um objeto que cumpre funções básicas de um objeto primordial ou atua como um representante dele, todos os mecanismos de denegação (podendo chegar, em níveis mais comprometidos, às cisões) serão acionados para, conforme a descrição do casal Nicholas Abraham e Maria Torok (1987), manter o status quo tópico. As recusas, denegações, incorporações, formações de cripta etc. funcionariam para manter inalterada a estrutura endopsíquica $^{28}$.

Mantenhamos, então, essa ideia de um luto interminável à nossa vista. Porém, não nos deixemos enredar por esse labirinto de desvios e interrupções (mas é possível? É possível guardar e comer o bolo ao mesmo tempo? É possível manter distância? Talvez nós também já estejamos sendo atraídos para essa malha literária e labiríntica).

Trause, escritor experiente e figura de destaque para Orr, insinua, por suas ações e comentários, que seus lutos são interrompidos. O jogo especular com Orr ganhará força no transcorrer da obra, beirando, por vezes, inclusive, a competição. Uma imagem interessante dessa ligação de sangue (filial?) entre Orr e Trause é que ambos carregam, ao seu modo, os

\footnotetext{
${ }^{28}$ Isso ocorreria numa dimensão de fantasia, já que o processo lento e gradual da assimilação via introjeção não ocorre e é substituído por uma fantasia de incorporação.
} 
signos da morte e da doença. Orr, recorrentemente, vive a desagradável situação de ver seu nariz sangrar, como efeito ainda do seu desarranjo corporal. A vida, ou os rastros da morte, escorrem pelos orifícios. Trause por sua vez, além de ser um veterano de guerra (lutou no Pacífico na Segunda Guerra), sofre com uma flebite na perna, cujo agravamento poderia levar a consequências mais sérias. O sangue no nariz de Orr, a inflamação nas veias da perna de Trause que podem arrebentar: estranha conexão entre enfermos. Poderíamos dizer que Orr vive o sangue que jorrou das veias que ainda não estouraram em Trause.

No entanto, Trause, sempre escondia as coisas (ocultava desde os livros aos demais segredos) e, como alguém bastante calejado por ter visto a morte de perto, não reclama de nada e não fala de suas dores (e, talvez por isso, carrega uma bomba-relógio dentro de si).

Porém, se Trause não demonstra mais abertamente seu sofrimento, outros o farão mais claramente, perlaborando melhor os lutos.

Richard, irmão da falecida Tina, encontra-se com Trause para conversar, coisa que não faziam desde a morte de Tina. Trause o tinha como uma figura simplória, com pouco ou nenhum interesse em relação aos objetos culturais tão caros a Trause. Apesar disso, o encontro entre os dois, relatado a Orr, havia impressionado muito a Trause. Ele, ao rever Richard, revê a esposa. Olha para os olhos dele e a enxerga, na sua versão dupla e masculina. A sobreposição de rostos o arrepia. O que viria a seguir, no entanto, segundo Trause ao relatar o encontro para Orr, seria mais fantástico ainda.

Richard, procurando alguma coisa em uma caixa de papelão na garagem da casa, encontrou uma espécie de relíquia. Acha um visor 3-D da época em que era ainda menino, nos anos 50. O brinquedo tinha sido uma febre à época, mas Richard mal se lembrava dele. A família utilizara apenas um rolo de fotos, com doze slides, e depois o artefato fora esquecido, jogado ao olvido. Mas os mortos ressuscitam e buscam contato novamente com os vivos. Richard tenta usar o aparelho e, para seu espanto, o aparelho funciona e um mundo mágico se descortina para ele, numa passagem miraculosa para outro tempo. O visor era uma lanterna mágica para o passado e, ao mesmo tempo (e a sobreposição de tempo aqui é crucial, levando a um colapso das temporalidades), um objeto testemunhal deste.

O passado reaparece inteiro à sua frente, com cores e brilho, animado pela máquina que permite a viagem no tempo. Voltou para 1953, na sala da casa de sua família. Os momentos da festa de aniversário de dezesseis anos de Tina estavam ali, e a ambiência afetiva do momento lhe voltou todo à lembrança.

As fotografias, em Auster, como vimos no primeiro ensaio e iremos retomar no próximo capítulo, cumprem um papel importante de abertura de sepulturas e resgate de 
ausentes. Em enredos de família, no registro do passado ancestral, ou mesmo em fotomontagens que procuram capturar o aspecto fugidio do passado (tornado presente novamente, em ilusão), as fotografias funcionam como uma espécie de cordão umbilical ligando o(s) referente(s) da foto e quem as vê, para usarmos as belas imagens de Susan Sontag que Barthes recupera. Barthes não reduz a fotografia a uma mera reprodução da realidade. Para ele, a fotografia contém uma emanação, um contágio daquele que ela traz aprisionada na imagem congelada.

A foto é literalmente uma emanação do referente. De um corpo real, que estava lá, partiram radiações que vêm me atingir, a mim, que estou aqui; pouco importa a duração da transmissão; a foto do ser desaparecido vem me tocar como os raios retardados de uma estrela. (Barthes, 1984, p. 75)

Embora Barthes não viveu para ver as maquinações da tecnologia, poeticamente sua ideia nos interessa.

Quando Richard regressa à sala de sua casa no passado, naquele dia da festa, o efeito de emanação mágica da foto, o cordão umbilical invisível que liga o referente da foto a quem a vê, como sinais cósmicos de uma estrela distante cuja luz chega tardiamente (a luz sendo a celebração de um corpo talvez já morto), esse efeito encantado é intensificado ainda mais pelo aparato 3-D que permite animar as fotos:

Todo mundo nelas parecia vivo, transbordando de energia, presente no momento, uma parte de algum eterno agora que continuou se perpetuando durante quase trinta anos. Cores intensas, minúsculos detalhes brilhando com toda clareza, e uma ilusão de espaço circundante, de profundidade. Quanto mais olhavas os slides, disse Richard, mais sentia que podia ver as figuras respirando e, cada vez que parava e passava para a seguinte, tinha a impressão de que se olhasse um pouco mais - só mais um momento - elas realmente começariam a se mexer. (Auster, 2003, p. 40).

Richard torna-se, deste então, um adicto do passado. Revê todos os dias o show de imagens. Figuras congeladas que, pela luz do retroprojetor do aparelho e pelo mecanismo tridimensional, voltavam quase a se mexer, ganhando vida e se recusando a morrer. A fotografia, continuando na linha de pensamento de Derrida, traz embutida em sua própria estrutura a morte projetada daquele que está ali, como se já implicando seu futuro desaparecimento (mesmo quando encontro uma foto muito recente de uma pessoa, não posso saber a priori se quem olho está ou não ainda vivo; sua morte está sempre anunciada e assombra a foto, e o mesmo vale quando olhamos nosso próprio retrato). Todavia, no aparelho 
de Richard, com sua intensidade das cores e o espetáculo do efeito de tridimensionalidade, a morte embutida a priori em qualquer fotografia parecia, inicialmente, ser suprimida.

Afastando-se da família e filhos, que reclamavam sua presença, Richard ia aos poucos se desmaterializando e se espectralizando em seu compulsivo abraço com os muito já cadáveres das fotos. Numa delas, estavam perfilados o pai, a mãe, a irmã e ele, o único ainda vivo. Surgem as primeiras lágrimas explícitas no livro.

Eram só os quatro - de braços dados, um encostado no outro, uma fileira de quatro rostos sorridentes, ridiculamente animados, fazendo careta para a câmera - e, quando Richard colocou essa no visor pela segunda vez, seus olhos de repente se encheram de lágrimas. Foi essa que me derrubou, ele disse, essa que foi demais para ele. Estava na varanda com três fantasmas, concluiu, sobrevivente daquela tarde de trinta anos atrás, e depois que as lágrimas começaram não havia mais como parar. Baixou o visor, cobriu o rosto com as mãos e começou a soluçar. Foi essa palavra que ele usou quando me contou a história: soluçar. 'Solucei até virar do avesso', disse. (Auster, 2003, p. 41)

O gesto de levar as mãos no rosto, como se as lágrimas e a dor forçassem a não ver mais aquilo. Richard só é interrompido nessa descida ao passado-túmulo pela quebra da máquina. Sabendo dos perigos desse instrumento, decide não consertá-lo nem mais ligá-lo. O problema do luto nunca realizado de Trause é revisitado por Richard, que, ao que parece, consegue desatar os últimos fios luminosos com seus entes. Não se deixa aprisionar no arquivo dos mortos. Trause acha a solução pobre, mundana demais.

Mas voltemos a Orr...

Orr queria escrever algo, queria realizar um exercício, mas com o propósito de convencer a si próprio que não perdera sua capacidade de escrita. Não sabe para onde ir, por onde começar.

Orr precipita-se, como um cego, rumo ao seu abismo. Sua lembrança flutua em torno da uma conversa que tivera certa vez com Trause sobre se os juízos fundamentais dos romancistas mudavam conforme sua obra prosseguia (e a imagem de um escritor que, em sua obra, permanece envolto com as mesmas questões, preso sempre aos mesmos “juízos”, guarda certa semelhança com um enlutado que está congelado no tempo).

O que John Trause oferece a Orr? Ele sugere, numa oferta aparentemente gratuita (e existe, nessa economia do dom, um gesto puramente gratuito?), que Orr escreva algo a partir de uma passagem do livro de Dashiel Hammett, $O$ falcão maltês. Trause, e não sabemos 
nunca se ele mantém intenções secretas, se há alguma possível manipulação de sua parte, dá a isca: ele sugere que Orr poderia escrever e dar continuidade a uma passagem do livro de Hammett, um fragmento inacabado dentro da história. Nessa história dentro da história, a cada descida para dentro desse labirinto com múltiplos andares, ficamos mais desorientados e nos sentimos como que presos num quadro do pintor Escher. Um corredor convida para ser entrado, e ao percorrê-lo, a sensação de voltar ao mesmo lugar fica cada vez mais pronunciada.

O episódio do livro de Hammett diz respeito à parábola de Flitcraft (como o nome sugere, um artista dos movimentos rápidos, dos voos e das fugas súbitas) ${ }^{29}$, uma estória que Sam Spade conta para sua interlocutora sobre um homem que abandona a própria vida e desaparece. Sujeito comum, bem-sucedido, pai, marido... sem nada a reclamar. Uma tarde, no caminho para o almoço, uma...

... viga despenca do décimo andar de um edifício em construção e quase aterrissa em sua cabeça. Cinco centímetros a mais e Flitcraft teria sido esmagado, mas a viga não o atinge e, a não ser por uma pequena lasca de calçada que salta e o atinge no rosto, ele segue adiante são e salvo. (Auster, 2003, p. 18).

Mas essa distância, esse intervalo que o separou da morte, ocasionando a irrupção de sua (nossa) ancestral vulnerabilidade, leva Flitcraft a empreender uma busca pelo acaso, abraçando a contingência como forma de vida. Para ele, "alguém levantou a tampa da vida e deixou que visse como funcionava” (Ibid., p.18). O acaso na existência, quando irrompe de forma traumática, rasga o fundamento de segurança ontológica (ilusório que seja) que mantinha o tecido da vida minimamente coeso. Para tentar fazer frente às forças aleatórias da vida, mimetizando-as como uma resposta frente ao choque traumático, Flitcraft abandona seu passado e sai em busca do desconhecido. Abandona carreira e família e, sem se despedir, vai para outra cidade.

O sonho da reescrita de um passado traumático com vistas a uma nova edição, revista e transfigurada, e em que o trauma é apagado, sonho que de Pierre Janet até os cognitivistas contemporâneos se faz notar, aciona o ímpeto de Flitcraft à precipitação existencial (que, como sabemos no transcorrer do livro, Orr nos conta que é um fim previsível, em que Flitcraft

\footnotetext{
${ }^{29}$ O leitor se torna obsidiado pelos nomes, pela insinuação de fantasmas por detrás deles. Em Auster, os nomes falam, mas também invadem outras histórias, atravessam paredes. Um personagem protagoniza uma história, para se tornar desaparecido ou apenas um vestígio em outra. Assim, Daniel Quinn, por exemplo, o escritor de estórias de detetives em Cidade de Vidro, terá seu nome mencionado novamente no livro No país das últimas coisas, mas agora somente num passaporte encontrado no chão, e que é um passaporte de um desconhecido para a narradora dessa distopia que percorre o século XX e seu rol de atrocidades e mortes em massa.
} 
sai de sua vida até então conhecida para, numa cidade distante, reencontrar o mesmo ethos cultural com o qual estava familiarizado antes, numa circularidade irônica. Sua fuga o leva de volta à sua vida).

Começa a escrita de Orr em seu caderno azul. Ele adota essa situação como um bom começo de história. A tampa da vida e, agora, a de sua caneta, são tiradas. A tinta, em sua escuridão, deixará fluir, em queda lenta, os mistérios que assombram o escritor.

Mudemos de plano, então, e entremos no caderno. Estamos na história que Orr começa a narrar. Seu personagem, sua versão de Flitcraft, é Nick Bowen, editor também, por volta de $35 \operatorname{anos}^{30}$, casado com uma mulher chamada Eva (talvez ambos vivam num estado pré-queda, anterior ao pecado original). Um pouco insatisfeito com o trabalho, com o casamento estacionado e um mal-estar difuso e vago, Nick Bowen recebe, em sua mesa, um manuscrito, chamado Noite do oráculo (o título do livro que lemos, portanto, é o título de um livro dentro do livro). Ainda que Orr ingenuamente afirme e acredite que Nick é o seu oposto, o que sucede é um claro jogo de espelhos, em que, não só Nick funciona como duplo de Orr, mas também muitas situações acontecem como reverberações da vida “real” (mas onde começava a realidade mesmo?...).

O tropo literário do mise en abyme, se não for contido, pode nos levar à vertigem da regressão infinita se alguma interrupção não acontecer. Contudo, nessa repetição especular, ou mesmo numa repetição na diferença, algo de um ritmo previsível pode ocorrer, e talvez por isso, e paradoxalmente, um fechamento continente se dê pela e na cadência formal. Os efeitos de dispersão e de confinamento, então, articular-se-iam dialeticamente (numa dialética sem síntese, para usarmos essa ideia de Merleau-Ponty). Essa duplicidade, esse jogo de abertura e fechamento, de sístole e de diástole literária, vai dando alguma pulsação ao nosso escritor, como se a vida estivesse lutando para retornar ao seu ritmo.

Se Orr volta ao mundo dos vivos, ele parece precisar de alguma ajuda, retomando a escrita como esse suplemento que o auxiliará na elaboração de seu desastre.

Então, voltemos a $\mathrm{Nick}^{31}$...

\footnotetext{
${ }^{30} \mathrm{Um}$ ano a menos que o autor da presente tese.

${ }^{31}$ De maneira obsessiva, paranoica, procuramos pelos nomes e suas ligações, numa filologia que brinca com o leitor. Nick remete a "entalhe, corte, incisão, momento crítico, lance favorável (no jogo de dados)", segundo o dicionário Michaelis. Mas um apelido, um nickname, também é algo a que se dá a alguém ou a si mesmo, com as mais diversas funções, e uma delas pode ser justamente a de ser um artifício para identificação e, simultaneamente, de velamento (velar uma identidade secreta). Além disso, o dicionário também nos dá, como um uso britânico, a ideia de “prisão”.
} 
Nick Bowen recebe o manuscrito intitulado a Noite do oráculo, escrito por Sylvia Maxwell nos anos 20. Não o lê ainda, mas se encanta com quem o entrega: a própria neta da escritora, Rosa Leightman. Encanta-se com a moça e fica claro para o leitor que o encontro de Bowen com Rosa reedita a primeira vez, o primeiro encontro extasiado que Sidney Orr tivera um dia com sua esposa, Grace. Rosa porta o mistério inocente, a beleza inconsciente e um “não sei o que mais” que cativa o personagem. Nick sente que o encontro com Rosa e uma posterior discussão com sua esposa na mesma noite ${ }^{32}$ o fazem perceber que alguma coisa dentro dele se rompeu, e que talvez seu casamento tenha fracassado.

Nick Bowen sai de casa e, no seu caminhar, em sua rota de direção, onze andares acima dele (vindo das alturas), a "cabeça de uma pequena gárgula de calcário presa à fachada de um prédio" (Auster, 2003, p.29) lentamente se solta e cai a poucos centímetros dele, estilhaçando-se em pedaços na calçada. A arte do acaso (embora o acaso, aqui, tenha sido engendrado, determinado e produzido pelas mãos do escritor em seu caderno, como se numa tentativa de controlá-lo) irrompe novamente nesse acontecimento.

A pedra era para matá-lo. Saiu de seu apartamento essa noite por nenhuma outra razão senão topar com aquela pedra e, se conseguiu escapar com vida, isso só pode significar que uma nova vida lhe foi dada - que sua velha vida está terminada, que cada momento de seu passado agora pertence a outra pessoa. (Ibid., p. 30)

Nick imediatamente toma um táxi na rua e, quando perguntado o destino, ainda tomado pelo choque, responde a primeira coisa que lhe vem à mente: o aeroporto. Orr interrompe a escrita e deixa seu personagem aí: suspenso no ar, rumo a um futuro incerto, em precipitação (o livro é todo composto de mudanças de planos e de narrativa).

Quedas e voos, interrupções e fugas... será que Nick (Orr) foge somente do acaso e da vulnerabilidade da vida, da morta encomendada pelo destino?...

Orr volta para seu lar original, que vai incorporando invisibilidades. Orr se assusta ao ver Grace na cozinha, não sabia que ela estava em casa. Grace, por sua vez, chegara do trabalho, fora até a sala do eremita-escritor doente, batera na porta e... não o viu. Nesse campo com forte poder de atração gravitacional que é o caderno e as estórias para Orr, algo vai roubando sua visibilidade, como se ele estivesse sendo sugado para dentro do caderno.

\footnotetext{
${ }^{32}$ Nessa mesma noite, Nick e Eva saíram para jantar num restaurante e lá encontram, por acaso, Rosa. Nick faz comentários elogiosos e francamente desajeitados sobre Rose, como se a ignorar a presença de Eva ali. Nick dá os seus primeiros passos na invisibilidade também.
} 
A sensação se amplia e ganha outras dimensões quando vai visitar a casa de John Trause na mesma noite, junto com a esposa. Orr havia roubado o apartamento de Trause para compor o de Nick na sua estória no caderno. Tinha gastado muito tempo pensando no apartamento de Trause, além de tê-lo visitado inúmeras vezes. Agora, quando entrava novamente nos aposentos de Trause na realidade, mas ainda impregnado pelo campo magnético do seu conto, parecia que Orr entrava em outro lugar, povoado com seres imaginários junto com as pessoas de carne e osso e os objetos que estavam ali. Numa sobreposição de dimensões, a fantasia e realidade se misturam e habitam a mesma morada imaginária-real. Uma espécie de "mil-folhas" francês, só que recheado e composto de camadas de memórias, criações e percepções, tudo ao mesmo tempo e no mesmo lugar.

Eu fazia parte daquilo que estava acontecendo à minha volta, e ao mesmo tempo estava separado daquilo, flutuando livremente dentro da minha cabeça, me imaginando sentado em minha mesa no Brooklyn, escrevendo sobre este lugar no caderno azul, e sentado em uma cadeira no andar superior de um duplex em Manhattan, firmemente ancorado em meu corpo, ouvindo o que John e Grace diziam um para o outro e até acrescentando algumas observações minhas. [...] Eu estava lá, plenamente participante do que estava acontecendo, e ao mesmo tempo não estava lá - porque não havia mais um autêntico lá. Em ambos os lugares ao mesmo tempo. No apartamento e na história. Na história no apartamento que eu ainda estava escrevendo na minha cabeça... (Auster, 2003, p. 33).

O deslocamento espacial e temporal, rompendo paredes e barreiras, possível para alguns fantasmas, começa a ou desmaterializar o personagem, ou a alargar e abrir portais em sua mente, o que talvez até permita a reaparição de outros fantasmas. Lembremos que estamos lendo um oráculo e que, pressupomos, ele deve, em alguma medida, conter saberes e poderes mágicos capazes de conduzir ao futuro para antecipar, esquadrinhar e desenhar destinos.

Espaços alargados, dimensões sobrepostas e simultâneas, presença em dois pontos do espaço ao mesmo tempo... a antiga geometria euclidiana tridimensional vai perdendo terreno para a não-euclidiana, com suas curvaturas e dobras dos espaços. Ou, se quisermos, começamos a abandonar o terreno da mecânica newtoniana - na qual corpos de massa maior atraem os menores para sua órbita - para vergarmos o espaço e entender a gravidade sobre o prisma do que deforma esse espaço. Nesses saltos, saímos da física newtoniana e adentramos os multiversos da astrofísica contemporânea e da bizarra mecânica quântica. A cada zeitgeist literário, a sua física correspondente. 
Mas voltemos à queda da gárgula. Façamos também esse deslize temporal entre espaços e temas.

A gárgula, nova versão da viga que caíra ao lado de Flitcraft, é agora duplamente literária - conto sobre conto. Não mais um simples pedaço de uma construção qualquer, mas sim já envernizada literariamente como gárgula, que, por sua vez, é uma ornamentação com fortes resquícios góticos e medievais, essa viga, ao virar gárgula, é transfigurada e recebe imagens do passado. A gárgula, espécie de figura híbrida, um tanto monstruosa, composição fantástica de pedaços de humanos, de animais e de seres imaginários, esse ornamento muito encontrado em igrejas de estilo gótico nos chama atenção por várias coisas.

Em primeiro lugar, a gárgula cumpria uma função hidráulica: por dentro dela, saindo pela boca, escoavam as águas das chuvas acumuladas nas partes superiores das catedrais. Ao nos determos aí, notamos quão estranha e interessante é essa imagem, a da chuva que cai e exige escoamento, como se alguma arquitetura e algum mecanismo simbólico fossem necessários para fazer correr a água que vem do altíssimo, preservando, assim, o próprio edifício que a recebe. Águas que são recebidas do alto, como que caindo à cabeça, e, numa outra volta do parafuso, criando ainda mais fantasmas e indecisões espectrais, aos moldes de Henry James (mas sem sua maestria), lembramos de Auster e o choro ancestral que percorre condutos silenciosos para, dentro do quarto de Anne Frank, Auster conseguir chorar o choro do pai (entre outros choros), chorar o choro que não pode vir diretamente nos olhos do pai, nem em Auster no início, mas apenas tardiamente, em outro aposento, com a ajuda de outras figuras (geralmente femininas). Nossos fantasmas (junto com os de Auster) vão fazendo aparições gotejantes.

O termo gárgula teria, como um possível ramo linguístico, se originado do francês gargouille, que tem raízes e parentescos com garganta e gargalo. Do latim, surge de gurgullio, gula. Em ambos os casos, temos delineada certa dimensão de oralidade que engole e pode regurgitar. Não estaríamos longe, em termos psicanalíticos, dos mecanismos e fantasias de incorporação (e seus fantasmas!). E, em muitos filmes de terror e suspense, os fantasmas possuem bocas abertas, buracos e cavidades escuras dispostas a engolir e devorar seus obsidiados e perseguidos. Na versão mais recente do retorno dos mortos-vivos, na febre do público pelos personagens “walking deads”, temos esses seres caminhantes ávidos por carne humana, e de modo geral o contágio da praga viral é geralmente pela boca, numa versão atualizada e mixada dos zumbis e vampiros dos antigos contos. É possível encontrar um 
parentesco tardio à referência aos muselmänner, os ditos muçulmanos ${ }^{33}$ dos campos de concentração nazistas, embora contextualizações precisassem ser feitas. Seja como for, nossa contextualização fantástica para o livro traz inúmeras ressonâncias com a morte - seja como impossibilidade, seja como recusa dela ${ }^{34}$.

Mas voltemos novamente às gárgulas e insistamos nos detalhes, gesto que nosso narrador também realiza. Há muita coisa encapsulada nos detalhes...

As gárgulas também apresentam, esteticamente, aspectos mais sombrios e assustadores. Nas catedrais (local do sagrado), suas figuras grotescas, assustadoras e intimidadoras podiam alertar, de um lado, para o mal que ainda viceja nos corações humanos, exigindo constante vigília diante dessa noite interna, e, de outro, poderiam funcionar para afugentar os maus espíritos. Na literatura de ficção de estilo gótico, as gárgulas ganham vida e voam (um voo que porta certo terror e morte). Em Auster, elas saltam dos prédios e se lançam ao humano, que, em resposta, salta e voa para uma outra vida, mas a partir de um contágio da e pela morte. A morte petrificada - e que petrifica em alguma medida o ser - provoca progressões. Falaremos em instantes dessa progressão, desse voo e dessa decolagem, mas ressaltemos ainda alguns pontos.

É interessante notar, então, que essa dimensão do sagrado (os templos e as catedrais) é perpassada por elementos que, para alguns, remete a temas, imagens e divindades pagãs ${ }^{35}$. As gárgulas, assim, já seriam uma espécie de composto cultural híbrido, assimilando (ou melhor, incorporando) elementos pagãos ao cristianismo medieval. Essa temporalidade sobreposta, numa acumulação incorporante, já revela, em si mesma e em seus artefatos culturais, uma dimensão quimérica. De fato, algumas gárgulas também são denominadas de quimeras. Sua combinação de elementos heteróclitos geram monstros inclassificáveis (as quimeras são um desafio às classificações e aos conceitos ordenadores).

\footnotetext{
${ }^{33}$ Um das origens do termo empregado referia-se aos internos dos campos de extermínio que, prostrados, balançavam-se repetidamente, gesto que se assemelhava aos muçulmanos em oração. Tais pessoas, tendo ultrapassado certo limiar não retornável do mundo da vida, numa total desesperança em relação à continuidade do existir e ao futuro, dado o horror a que tinham tocado, apenas permaneciam vivos pelo corpo, por fatores estritamente biológicos, mas despidos de vida humana e de interação. Primo Levi, em Afogados e sobreviventes, relatava a dificuldade dos demais internos em olhar para esse espelho petrificante e assustador. A referência religiosa, numa espécie de teologia inversa, talvez pervertida, destaca a oração fiel dos humanos, mas num mundo sem Deus e esvaziado completamente de sentido.

${ }^{34}$ No seriado americano intitulado Walking dead, o drama da fuga dos mortos-vivos se torna mais pronunciado quando quem é tomado por essa zona cinzenta entre a morte e a vida são os próprios familiares dos ainda vivos. Há uma tensão recorrente entre acertar a cabeça dos zumbis e talvez se deixar contaminar por eles, numa culpa por não salvá-los.

${ }^{35}$ Material consultado na internet, acessível no endereço:

http://www.cwrl.utexas.edu/ bump/oxford/gargoyles.html.
} 
Na embriologia, usa-se o conceito e o nome de quimera para nomear o resultado de determinadas alterações na combinação do DNA, que podem ocasionar aberrações curiosas, como no caso que se tornou famoso de uma mãe que teve filhos cujos DNAs não correspondiam aos seus, mas sim aos de sua própria mãe, avó das crianças. O processo aconteceu porque, ainda no útero, Lydia Fairchild ${ }^{36}$, ou melhor, seu embrião, assimilara-se ao embrião de sua irmã gêmea (também embrião à época, diga-se de passagem) no útero, o que ocasionou uma alteração na composição genética de Lydia, numa incorporação fantasmagórica embriônica (o legado de um imbróglio). Geneticamente, então, os filhos de Lydia seriam filhos de sua mãe, e não dela. Dado curioso também é que, em alguns raros caos, pelo fato das pessoas serem portadoras de células com origens genéticas diferentes do resto do organismo, pode ocorrer a alteração no desenvolvimento desses tecidos ou mesmo órgãos. Assim, alguns órgãos ou tecidos, por exemplo, podem até a envelhecer num ritmo diferente dos demais. Além disso, uma tendência a certas doenças autoimunes poderia ocorrer. Transpondo isso, em termos metafóricos, para a psicanálise, seria interessante investigar essa determinação temporal diferenciada no psiquismo, com seus rastros de “DNAs” psíquicos ancestrais. Porém, mesmo no plano ontogenético, como no caso do falsoself winnicottiano, temos a formação e a evolução de tempos diferentes, um mais infantil e regredido, outro aceleradamente mais adulto e “sábio” (como o bebê sábio de Ferenczi).

Mas não queremos somente colocar goela abaixo no leitor essas imagens quiméricas. Cremos que elas nos dizem algo, mas voltemos logo ao texto para não ficarmos enredados nesse imbróglio.

Nick Bowen, personagem de Orr, salta para sua imprevisível vida nova. Foge da esposa e do trabalho, carregando consigo apenas a lembrança e o conhecimento trazido pela quase mortífera gárgula e a cópia do livro Noite do oráculo, que lhe foi dado por Rosa.

Nick quer se livrar do seu passado, apagar seus registros, e afirma para si mesmo que deve apenas ler o livro que Rosa lhe passou.

Ele o lê, profundamente, em uma só noite. Uma noite que mergulha em outra.

Noite do oráculo, o livro dentro do livro, conta a estória de um combatente ferido da Primeira Guerra Mundial, Lemuel Flagg, que perdera a visão devido a uma explosão. O trauma e/ou a perda da visão lhe permitiu, contudo, enxergar o futuro, transformando-o numa espécie de profeta (um leitor de oráculo). Entretanto, em uma de suas visões, antecipa a

\footnotetext{
${ }^{36}$ Pouparemos o leitor da leitura do sobrenome da pessoa portadora dessa síndrome, tal como fizéramos com os personagens de Auster.
} 
traição da noiva e a ferida narcísica disso lhe é insuportável. O personagem (melodramaticamente) se mata. Mas estamos saltando... (estamos querendo fugir também?...).

O transe de Lemuel Flagg lhe dá o dom da profecia, e são em estados de transe, quando “ele cai no chão e começa a se sacudir como um epilético” (Auster, 2003, p.62), que as visões lhe surgem. A benção e a maldição de Flagg, antecipando-se ao futuro com seu oceano de eventos - traições, assassinatos etc. -, faz Flagg querer fugir, escapar de seu destino. Foge do seu destino, mas talvez para mergulhar ainda mais nele, se entendermos (e o texto nos dá indício disso) que, para Flagg, a traição seria sua morte. Então, saber da traição da noiva apenas seria a antessala da verdadeira morte: seu suicídio.

Nosso profeta cego, um Édipo que possui o oráculo em si mesmo, nos aponta para esse jogo de vislumbre do futuro e de fuga. É interessante também notar que, embora Flagg seja uma versão masculina, nos antigos mitos gregos e pré-gregos sobre os oráculos eram as figuras femininas, em geral, que entravam em transe e emitiam a profecia (e o estado de transe acontecia, em Delfos, a partir dos vapores que emergiam ou da água ou de uma fenda na terra). Caberia a uma figura masculina, intérprete das palavras, fazer a justa leitura da fala confusa das sacerdotisas, as pitonisas de Delfo. Cassandra também é outra referência, e Auster em Invenção da Solidão comenta sobre essa "Esfinge Negra”, o que também nos convirá aqui, citando-o:

O futuro tomba de seus lábios no presente, cada coisa exatamente como vai acontecer, e o destino dela é nunca acreditarem no que diz. Louca, a filha de Príamo (...). Falar do futuro é usar uma língua que está sempre adiante de si mesma, declarando ao passado coisas que ainda não aconteceram, declarando para um "já" que está para sempre atrás de si mesmo e, nesse espaço entre enunciação e ato, palavra após palavras, uma fenda começa a se abrir, e contemplar tamanho vazio por qualquer intervalo de tempo é ficar atordoado, sentir-se despencar no abismo. (Auster, 1982. pp.143-144).

No nosso livro, ou melhor, no livro-dentro-do-livro-dentro-do-livro, Flagg não deixa de remeter ao seu duplo superior, Nick, que lê o livro "Noite do oráculo”. As mensagens proféticas, então, precisam da ajuda de um intérprete, uma hermeneuta. No nosso caso, para nosso personagem, essa figura mediadora (mensageiro que faz a passagem entre mundo dos vivos e dos deuses) será cumprida pelo livro (e o caderno que se torna livro). É o livro que serve de anteparo e mediação para o que se passa, tanto em relação ao futuro, mas, também, quanto ao passado. Mas não sabemos se Nick sabe ler os signos do destino. E o leitor, por sua vez, também parece ficar num estado meio narcotizado, em transe, entre as imagens que prenunciam algo e a obscuridade dos personagens que, diante da noite da vida, vagam ora 
feito cegos, ora buscando encontrar sinais fidedignos de como prosseguir. Poderíamos dizer que Orr, talvez por intermédio de Nick, tenta empreender por meio do oráculo-caderno uma leitura da existência que se anuncia somente através de palavras ou imagens nebulosas (vindas do vapor da terra), como as de uma profetisa.

Nick lê o livro. Orr o escreve, e lê o que escreve. O caderno de Orr vai ganhando uma aura mágica, como os cadernos do destino que outro autor de ficção científica, Phillip Dick mostra em um de seus contos ${ }^{37}$. Nick usa o livro para lhe servir de anteparo e trampolim para o que lhe vem a seguir. Nick não nos diz (nem Orr nem Auster) o que ele entende do livro, apenas o carrega como mola propulsora.

\begin{abstract}
A história de Lemuel Flagg o afeta profundamente, mas Bowen não lê Noite do oráculo porque está querendo se emocionar ou divertir, e não mergulha no romance a fim de protelar a decisão do que fazer em seguida. Ele sabe o que tem de fazer em seguida, e o livro é apenas o meio que tem à mão. Tem de treinar para não pensar no passado. Essa é a chave para toda a louca aventura que começou para ele quando a gárgula se espatifou na calçada. Se perdeu sua velha vida, tem de agir como se estivesse acabado de nascer, fingir que não está mais sobrecarregado de passado do que um bebê. Tem lembranças, claro, mas essas lembranças não são mais relevantes, não são mais parte da vida que começou para ele e, sempre que se vê deslizando para pensamentos sobre sua velha vida em Nova York - que foi apagada, que não é agora nada mais que ilusão -, faz tudo o que está em seu poder para tirar da cabeça o passado e se concentrar no presente. Por isso lê o livro. Por isso continua lendo o livro. Precisa atrair-se para longe das falsas lembranças de uma vida que não lhe pertence mais e, como o manuscrito exige total submissão para ser lido, uma atenção ininterrupta tanto do corpo como da mente, ele pode esquecer quem era quando está perdido nas páginas do romance. (Auster, 2003, p. 65).
\end{abstract}

Aqui, o livro faz saltar para frente e, simultaneamente, esquecer o passado. Numa intricada sobreposição de passado e futuro, de escapes da existência rumo à outra coisa, talvez apenas para reencontrar o próprio passado, pressentimos, nós, leitores-aprendizes de profetas, que estamos lidando com artistas do escape (e que escapam de nós também). Nick salta, a esmo, para Kansas City, no interior do nada. Pega um táxi assim que sai do aeroporto de Kansas e o motorista, Ed Victory, é o seu condutor (talvez Ed seja seu Caronte, a conduzir Nick na descida ao Inferno, tal com na Divina Comédia de Dante).

\footnotetext{
${ }^{37}$ O conto de Phillip Dick, Adjustment Team, que deu origem (uma adaptação modificada) ao filme Agentes do destino (2011), conta a história de um misterioso departamento que regula o destino, encontros e acontecimentos na vida das pessoas. O desenrolar do destino - ou seu desvio - são monitorados a partir de cadernos que vão desenhando, "ao vivo", a trama da existência. Quando um evento sai do esperado, o que seria uma espécie de colapso do que fora orquestrado, os agentes entram em cena para fazer os ajustes necessários.
} 
Ed Victory, um negro alto e gordo, conduz Nick para o melhor hotel da cidade. Ed conta que o hotel já sofrera, um ano atrás, um desastre enorme, em que mais de cem pessoas morreram com a queda de uma galeria, cuja estrutura era sustentada por vigas que cederam. Na galeria suspensa havia um espetáculo de dança (fascinação de Auster). Nick não teme ir para o hotel. Para quem já sobrevivera a um raio (um Witz?) uma vez, isso não seria problema se acontecesse de novo. Ed estava realizando sua última corrida de taxi, após trinta e quatro anos de condução, e Nick é o seu último passageiro. Ed Victory entrega-lhe seu cartão de apresentação, em que está inscrito seu telefone, endereço e a ocupação de Ed, sua empresa, à qual dará prosseguimento após essa última corrida. O cartão diz “GABINETE DE PRESERVAÇÃO HISTÓRICA” e, embaixo, o curioso número de telefone: 816-765-4321 (um número que parece descender até o final, o zero absoluto, talvez nunca alcançável).

Nick se hospeda no hotel. Não pensa em Eva, cujo desespero se assoma conforme Nick não volta para casa e não dá sinal de vida. O desespero de Eva percorre todas as fantasias possíveis para rastrear esse desaparecido. Do medo de um sequestro, um rapto, passando por uma possível traição (Eva lembra-se de Nick falar de Rosa) até chegar à ideia de que talvez Nick esteja enlouquecido. Nick, por sua vez, ligara para Rosa, deixando na secretária do telefone uma declaração de amor. Rosa pega essa mensagem uma semana depois somente, o que vai levar a uma busca trágica. Rosa e Eva saem em busca de Nick, esse agora literalmente desaparecido.

Auster também é cativo dessa imagem de um desaparecido que parece olhar, do outro lado, os vivos correrem ao encalço dele, numa estranha patologia narcísica. Nunca sabemos de onde Auster retira essa matriz, mas a hipótese de seu pai como feiticeiro a engendrarinstalar detetives que o encontrem e, quem sabe, o salvem, possui um peso metafórico e gravitacional muito forte (mas, como afirmamos anteriormente, estamos na transição entre modelos gravitacionais, entre a física das grandes massas, as dobras do espaço e a física de partículas e subpartículas). O senhor Sam Auster é um artista do escape também. Quanto mais Paul Auster tentasse achar o pai, a partir, por exemplo, dos fragmentos esparsos e sem sentido, das lembranças emocionalmente vazias e dos objetos do fantasma, mais seu pai escapulia para dentro do próprio vazio. Diante da impossibilidade de dizer o pai, esse ser indescritível em sua ausência em vida, cheia de segredos, é preciso reconstruí-lo pra tentar, quem sabe, salvá-lo. E nessa luta desesperada, o risco de não ter sucesso em salvar o desaparecido (ou o morto) é que a punição (culpa) ganha a forma de uma exigência mortífera 
de abraço: junta-se aos mortos por culpa de não ter conseguido salvá-los ${ }^{38}$. Auster abre criptas do seu passado, fotografias de fantasmas (como a que mostramos no primeiro ensaio, com o pai multiplicado em vários) e de fantasmas soterrados (os dedos do avô na foto rasgada pela avó), mas, quanto mais desenterra os mortos, quanto mais abre as criptas, mais os fantasmas saem dela, e mais Auster, ou melhor, seus personagens, parecem ser engolidos por eles. Se Auster não consegue alcançar o pai em suas memórias, tentará habitar o vazio como o lócus mais fidedigno de onde pode falar, ou melhor, escrever sobre o pai e alcançar algum rastro dele. No entanto, ao caminharmos e sermos sugados para o vazio, para dentro do buraco negro, após certo horizonte de eventos ${ }^{39}$, os corpos (e mesmo a luz) não pode mais retornar. Ao incorporar um objeto, ao aprisioná-lo, por uma reversibilidade interna sinistra, também se é aprisionado por ele, de dentro. Em Auster, vemos o aprisionar da dor do outro, ou melhor, o outro espectral com uma dor igualmente espectral. Auster, segundo nossa leitura, poderia responder à mesma pergunta que a mãe de Derrida, já bastante enferma, respondera quando alguém perguntara o que lhe doía: o que lhe dói? "Dói-me minha mãe!” (Derrida, in: Bennington; Derrida, 1996, p. 45) Em Auster: dói-me meu pai!

Auster recorre a outras dores, outros pais e outras memórias para poder recriar algo dessa inefável (mas muito cortante) dor ancestral. Como um caranguejo-ermitão, que não possuindo exoesqueleto próprio, o rouba de outros, das conchas (ou, numa versão pósmoderna, das latas de tomate no fundo do mar), trocando de carapaça à medida que cresce, talvez Auster precisasse se abrigar em outros refúgios para se encolher e recolher essa dor, abrigando também a culpa por ter invadido e vasculhado refúgios secretos alheios, o do pai principalmente. Auster rouba estórias e instala-se em outros escritores, para, a partir daí, circunscrever e dar nascimento à sua obra. O quarto do escritor, assim, é como uma morada em que comparecem muitos outros escritores. O quarto como cápsula narcísica, fonte de renovação e renascimento, mas também local para sepultar os mortos.

Mas Nick não parece sofrer dessa culpa mencionada acima. Ele abandona Eva e tudo o que diz respeito ao seu próprio passado, reencena a recorrente cena do desaparecido que tem um séquito atrás dele e parece fugir para outro lugar. Talvez Nick esteja já tão dentro de uma

\footnotetext{
${ }^{38}$ Se todo abusador foi também um abusado, independente da modalidade de abuso, do trauma perpetrado e recebido, temos que a vítima na ponta da cadeia de traumas herdará a responsabilidade por não ter conseguido salvar seus pais e ancestrais, salvaguardando-os, então, dentro de si, de maneira fantasmática. Leonard Shengold (1989), em seu livro Soul murder, explicita bem essa dimensão dos filhos sentindo-se obrigados a assumir a culpa pelos traumas, de maneira a preservar o laço com eles. O conceito teórico, aqui, é claramente de filiação ferencziana. Porém, Shengold não estende sua análise para abranger a dimensão transgeracional, ainda que ela esteja implícita no conceito.

${ }^{39}$ Horizonte de eventos é um termo da astrofísica para designar um limiar a partir do qual nenhum objeto (nem mesmo a luz) consegue escapar da força gravitacional de um buraco negro.
} 
concha, de uma concha alheia, que ele já não sabe mais que está aí, talvez desde muito tempo. Quem sabe Nick esteja na concha de Orr, ou na de Auster, ou na nossa, não o sabemos!...

Nick, sem dinheiro (Eva, por medo, havia bloqueado os cartões de crédito), procura Ed Victory e aceita trabalhar no GABINETE DE PRESERVAÇÃO HISTÓRICA.

Pega o sinistro cartão de visita de Ed e vai até o endereço.

Ed Victory mora num minúsculo quarto do último andar de uma pensão, num bairro pobre e afastado.

Nick entra no quarto, que, na mesma série de quartos da obra de Auster, revela a sobriedade e a reclusão de um eremita.

\begin{abstract}
Bowen acomoda-se na cadeira de madeira de encosto reto e olha em torno do quarto pequeno e arrumado. Faz pensar em uma cela de monge, ou no refúgio de um ermitão: um lugar neutro, espartano, sem nada além do essencial para viver. Uma cama de solteiro, uma cômoda de gavetas pequena, um fogão de chapa elétrica, uma geladeira tamanho frigobar, uma escrivaninha e uma estante com dezenas de livros, entre eles oito ou dez dicionários e uma coleção bem manipulada da Collier's Encyclopedia em vinte volumes. O quarto representa um mundo de contenção, de interioridade e disciplina e, quando Bowen olha de novo para Victory, que está calmamente olhando para ele da cama, percebe um último detalhe que havia lhe escapado antes. Não há quadros nas paredes, nenhuma fotografia ou objetos pessoais expostos. O único enfeite é um calendário pregado na parede acima da escrivaninha - de 1945, aberto no mês de abril. (Auster, 2003, p. 72)
\end{abstract}

Um quarto imobilizado no tempo, preso a uma data, que nunca mais passou: abril de 1945. Um quarto sem janelas simbólicas e com um calendário-relógio marcando uma data que nunca mais passou.

Nick conta sua situação, a falta de dinheiro e a disposição de trabalhar por qualquer quantia, desde que tivesse uma ocupação. Ed estranha o fato de um homem bem-vestido, hospedado num hotel caro, não ter dinheiro e querer trabalhar com ele. Mas Ed é discreto e o aceita como funcionário. Ed pega seu maço de cigarro, acende um, dá uma tragada prolongada e tosse copiosamente.

Anos de catarro coagulado metralham dentro de seus brônquios contraídos, e durante vinte segundos o quarto se enche de convulsas explosões sonoras. Quando abranda, Ed sorri para Bowen e diz: Quando me perguntaram por que eu fumo, respondo que é porque gosto de tossir. (Ibid., p. 72). 
Uma tosse do fundo dos pulmões e uma boca que emite fumaça como uma chaminé. O corpulento Ed Victory abriga, além da gordura, uma luta interna de catarros coagulados, disparando a esmo dentro dos pulmões. E uma fumaça regurgitada, deixando escapar os sinais da morte...

Ed acerta o contrato com Nick e oferece um quartinho no GABINETE DE PRESERVAÇÃO HISTÓRICA para Nick se acomodar. Explica também do que se trata o seu gabinete. Afirma que é um museu, e não tanto uma empresa. Um arquivo particular. A organização do arquivo, até agora, tinha sido espacial. Agora, Ed queria incluir a variável temporal, cronológica, para dispor seus documentos-relíquias.

Dirigem-se ao gabinete, andando nove ou dez quarteirões, até desembocarem num pátio de estocagem em frente ao Missouri, a fronteira liquida. Continuam andando até a água estar em frente deles, com nenhum prédio mais por perto. Local vazio.

Os signos do passado são apenas os trilhos de trem que se encontram ali, formando malhas cruzadas, mas sem mais vagões, conduzindo do nada a lugar nenhum. No meio dos trilhos de trens fantasmas, após saltarem por alguns, Ed mostra...

... um quadrado de madeira sem pintura, batido pelo tempo, embutido no cascalho, uma espécie de comporta ou alçapão, e mistura-se tão discretamente com o meio circundante que Nick duvida que tivesse encontrado sozinho. (Ibid., pp. 85-6).

Abrem a escotilha e descem por uma pequena escada num túnel de concreto, quatro metros abaixo da superfície. No fundo, Nick vê, com a ajuda da luz presa à escotilha lá em cima, que estão diante de uma porta de madeira compensada. Há apenas um cadeado à altura do peito, sem maçanetas. Ed retira um molho de chaves do bolso e abre a porta com uma delas. Quando Ed liga os interruptores de luz, que se acendem em sequência, o que Nick vê é um grande depósito, sem janelas, que abrigava corredores de enormes estantes de metal, subindo até o teto. A impressão que tem é de estarem em uma biblioteca, ou uma espécie de arquivo gigante: eis o gabinete de preservação histórica de Ed.

Ed conta a origem do arquivo, uma origem marcada pela catástrofe e pela esperança de não se abater a ela, fazendo um registro excêntrico da humanidade. Nick aventura-se a olhar o arquivo.

Percorre o primeiro corredor e descobre que as estantes estão tomadas de listas telefônicas. Centenas de listas telefônicas, milhares de listas telefônicas, arrumadas em ordem alfabética por cidade e colocadas em 
ordem cronológica. Por acaso se encontra na fileira que contém Baltimore e Boston. Conferindo as datas das lombadas das listas, vê que o livro mais antigo de Baltimore é de 1927. Existem várias falhas depois disso, mas a partir de 1946 a coleção está completa até o ano atual, 1982. O primeiro livro de Boston é ainda mais antigo, datando de 1919, mas aí também faltam muitos volumes até 1946, quando os anos todos passam a figurar. Com base nessa evidência, Nick conclui que Ed começou a coleção em 1946, o ano seguinte ao final da Segunda Guerra Mundial, que é, por acaso, o ano que o próprio Bowen nasceu. Trinta e seis anos dedicados a uma empresa vasta e aparentemente sem sentido, que cobre exatamente a duração de sua própria vida $^{40}$. (Ibid., p. 87)

Um imenso arquivo de listas telefônicas, de pessoas e cidades do passado até o presente do texto, de pessoas vivas e desaparecidas. A lista não se restringia somente aos Estados Unidos, mas também a muitas cidades da Europa. Nick vê que Ed conseguiu comprar, inclusive, uma lista telefônica de Varsóvia de 1937/38: "Spis Abonentów Warszawskiej Sieci TEFEFONÓW”"41 (Ibid., p. 88). Nick sente a tentação dos fundos das entranhas, ou dos pulmões, para retirar a lista da estante e lhe ocorre que "todos os judeus listados naquele livro morreram há muito tempo - assassinados antes mesmo que Ed tivesse iniciado sua coleção”. (Ibid., p. 88; itálicos nossos).

Nick arrepia-se com a imagem e não entende o que está acontecendo ali, naquela espécie de monumento soterrado, dedicado aos mortos e aos vivos. Ed conta os antecedentes da ideia de ter o arquivo. Ed Victory havia descido até o inferno...

Eu vi todas as coisas, Homem do Raio. Desci até as entranhas do inferno, e vi o fim. Você volta de uma viagem dessas e, por mais que continue no meio dos vivos, uma parte de você vai estar sempre morta. (Ibid., p. 88)

Em abril de 1945, Ed Victory (e seu nome não é mesmo esse, no que estaríamos novamente às voltas com um criptograma) fazia parte da unidade americana que libertou o campo de concentração nazista de Dachau:

Trinta mil esqueletos respirando. Você já viu as fotos, mas as fotos não mostram o que era aquilo. Tinha de estar lá e sentir o cheiro você mesmo; tinha de estar lá e tocar com sua própria mão. Seres humanos fizeram aquilo com seres humanos, e fizeram com plena consciência. Aquilo foi o fim da humanidade, Mr. Sapato Bom. Deus desviou os olhos de nós e abandonou o mundo para sempre. E eu estava lá para ver. (Ibid., p.89)

\footnotetext{
${ }^{40} \mathrm{E}$ a do autor da presente tese.

${ }^{41}$ Auster recebera, de fato, essa lista de um conhecido, que sabia que Auster tinha ascendência polonesa.
} 
Victory, cuja vitória não é encontrada em nenhum lugar, salvo em sua esperança de arquivar e criar um altar para o fim e recomeço da humanidade, é aquele que desceu até o inferno, sentiu seu cheiro e seus demônios e voltou para o mundo dos vivos com o conhecimento macabro disso em seus pulmões e em seus arquivos internos. Ed era cozinheiro lá, responsável por alimentar os sobreviventes após a libertação e estabelecimento de sua unidade no campo. Os internos que conseguiam comer comiam feito loucos, para além da capacidade do estômago de conter o alimento, numa explosão de fome desmedida. Muitos, além de debilitados, estavam loucos. Uma mulher, cujos olhos dançavam de maneira insana nas órbitas, extremamente magra, equilibrava-se por efeitos misteriosos. Não pediu comida para ela, mas para o bebê que carregava no colo. Quando ela lhe deu a criança, Ed viu que estava morta, e fazia tempo. O rosto preto, enrugado, congelado. A mulher continuou implorando leite. E Ed despejou um pouco de leite na boca do bebê morto. A mulher saiu, segundo Ed, em felicidade, cambaleando mais alguns passos bêbados para então os joelhos cederem e soltar-se ao chão.

A imagem de horror é contada em linguagem simples, rasa, sem floreios, talvez como numa proibição de se fazer literatura disso, ou talvez pela própria simplicidade de Ed.

O arquivo-abrigo de Ed, construído nos anos 60, na época do auge da guerra fria, é uma espécie de bunker, pois Ed temia uma hecatombe atômica. A sucessão de catástrofes que se avolumam e crescem umas sobre as outras: a Segunda Guerra, uma catástrofe real; a Guerra Fria, um espectro que rondou o mundo. O bunker, assim, é uma construção com camadas de memória e história diferentes, mas que (re)ligam dores e desastres.

Ed tinha que guardar aquilo, não podia apagá-lo. Em grande medida, Ed Victory trabalha no registro da memória e do luto (melancólico ou não), ao contrário de Nick, que se desvincula do passado e se quer fazer uma tábula rasa. O arquivo-críptico de Ed é, segundo suas palavras...

uma casa da memória, mas também é um altar para o presente. Ao juntar essas duas coisas em um só lugar, eu provo para mim mesmo que a humanidade não está acabada. (Ibid., p. 88).

Ed Victory se dirigia a Nick, como lemos numa citação mais acima, como se ele, Nick, já tivesse visto as fotos dos internos dos campos. Mas como ele supõe isso? Como sabe se Nick algum dia viu alguma foto sobre Dachau (mesmo supondo que esse arquivo já faça parte do acervo da humanidade)? Ora, é Orr quem escreve a estória de Nick (e a de Ed). E Orr já viu por fotos. Ele menciona isso numa nota de rodapé. Havia retirado a história de Dachau, e da criança morta recebendo leite, do livro The Lid Lifts, de Patrick Gordon-Walker [“Abra- 
se a tampa”]. Orr nos reconta que a mesma história da criança morta fora retomada em outro livro também, o de Douglas Botting, From the Ruins of the Reich: Germany 1945-1949. Abre-se a tampa para ver a catástrofe e o fracasso do humano e abra-se a tampa da caneta para deixar fluir o sangue-tinta. Seja como for, há a inserção de uma mediação histórica, o livro. O livro que o autor, não estando lá no inferno, leu e teve uma visão - distanciada - do fim da humanidade. E Ed Victory alerta Nick (e, por tabela, Orr, o escritor) ${ }^{42}$ que a sua visão do inferno é uma visão por detrás de um vidro de proteção, hermeticamente isolado dos sons horripilantes do sofrimento e imune aos odores fétidos da vida sendo reduzida ao mais degradante. O escritor, Orr, tem uma visão sombria, é verdade, mas de segunda mão, a quilômetros e anos de distância. E Ed Victory, de maneira estranha, parece responder não a Nick, mas a Orr, seu autor, e desperta nele uma culpa bem estranha: a do sobrevivente que nunca esteve ou participou da catástrofe, mas ainda assim é um sobrevivente, com toda a diversidade de afetos que isso suscita (sentimentos conscientes ou não de triunfo, gozo, competição, ressentimento, culpa por não conseguir salvar os mortos etc.).

Auster reencena a culpa do autor que criou personagens que, como avatares do autor, percorrem caminhos e são lançados em missões cruéis, desumanas, mortíferas. Esses personagens, como no seu livro Viagens no Scriptorium, retornam, feito fantasmas, para cobrar responsabilidade do autor. Em certa medida, Auster herda o sofrimento dos seus antepassados e de sua comunidade pelo mundo afora, mesmo não tendo recebido esse conhecimento doloroso de primeira mão. Pelo contrário, ele escolhe se lembrar, silenciosamente em grande parte do tempo, dessa tradição dos oprimidos e esmagados pela indústria da solução final. Porém, ele precisa formar suas memórias numa posteridade, como se fossem pós-memórias, para usarmos os termos de Hirsh (2012), memórias construídas a partir de fragmentos transmitidos pelas gerações passadas, inclusive fragmentos envoltos em silêncio. Essas dores, como veremos, serão articuladas a outras dores, a outros rastros e ruínas, formando uma espécie de solidariedade pela catástrofe.

Mas voltemos ao Nick. Ele não passará batido por essa experiência. Não se sobrevive ileso a isso.

Já trabalhando com Ed, ajudando na reorganização do arquivo segundo a cronologia (como se a correção cronológica pudesse restabelecer a temporalidade fraturada e caótica, como se fosse uma cura pela História), Nick testemunha Ed um dia passar mal e o leva ao

\footnotetext{
${ }^{42}$ A delimitação entre os personagens, nesse momento, se colapsa também, e prenuncia que todos talvez já saibam alguma coisa uns dos outros, porque todos compartilham de uma mesma divindade que, como o Espírito Santo, inspira suas falas. Votamos a Auster, o autor, que talvez fale consigo mesmo por intermédio dos personagens, acusando-se por não ter estado lá e não ter visto o inferno com outros viram.
} 
hospital. Nick, com sua nova vida, recém-advinda do nada, reprogramado numa nova existência e vestindo as roupas de pessoas que, simbolicamente, ou estavam mortas ou eram desaparecidas (veste roupas de segunda mão, compradas na Missão da Boa Vontade a preços módicos), Nick volta para o gabinete após deixar Ed no hospital, e não sabe da morte de Ed instantes depois.

Nick pega as chaves e entra no bunker. Vai até o quartinho que lhe fora reservado, ao final da sala do arquivo. É um quarto pequeno, com poucos objetos e mobília, apenas o necessário para algum conforto, inclusive um aquecedor elétrico. A porta do quarto só abre de fora para dentro. Por dentro, é necessária a chave para destravá-la, pois só há uma fechadura. Nick vai dando seus passos para sua catástrofe pessoal. Faz rodeios inconscientes, vai até o quarto, mas volta para o molho de chaves deixado na estante. Vai até outra parte da sala pegar a lista telefônica de Varsóvia, porém, mais uma vez, coloca as chaves na estante. Isso não seria problema, pois ele precisa das chaves para abrir a porta. No entanto, nessa manhã, ele a deixou aberta. Quando volta para o quarto, cuja porta está aberta, não se lembra de trazer as chaves e, num gesto impensado e natural, chuta a porta e se tranca dentro. Quando se dá conta do que fez, ao não achar as chaves, solta um riso. Depois se desespera. Procura se acalmar e pensa que Ed uma hora chegará e abrirá a porta por fora. Lembremos ao leitor que estamos num bunker, alguns metros abaixo da superfície, no meio do nada. É um abrigo contra uma hecatombe nuclear. Nick, agora em passos largos para sua prisão final, mas ainda inconsciente do seu sepultamento, finge que a vida ainda continua.

Orr deixa Nick aí, incapaz de dar um final satisfatório à estória. Ele o pôs lá dentro, e temos muitos motivos para suspeitar de recusa de seguir de outra forma. A trama fecha-se aí. Orr finalmente sepulta seu duplo, como se desse um enterro simbólico para o fantasma que carregava dentro de si há tempos. Se, com sua narrativa, Orr buscava, mais ou menos inconscientemente, fazer um luto, o que acontece quando essa narrativa fracassa, quando ela não pode mais ir para frente? É a narrativa de um fracasso? Bem, talvez Orr tenha sido bemsucedido em narrar o fracasso, a interrupção. Nick Bowen é sepultado numa cripta. E podemos dizer, nessa mesma via, que também o caderno de Orr funciona como esse túmulo em que serão enterrados os mortos. Os fantasmas choram porque ainda não foram sepultados devidamente.

Orr, se M.R. Chang estava correto em seu ato-falho quando ouviu pela primeira vez o nome de Sidney Orr, pode ser compreendido como uma vacilação estrutural (um “ou” [or]). Orr hesita quanto à sua existência, quanto ao seu caráter de realidade, de pertencimento ao mundo dos vivos. Mas Orr também hesita e treme ao ver os sinais do acaso e do furtivo que 
cruzam em seu caminho. Busca, a todo custo, amarrar os fios soltos, ligar os pontos, realizando uma espécie de “leitura paranoica” (Hirsch, 2012, p.74) da existência e das pessoas que circulam em sua vida. O comportamento furtivo de Grace, sua esposa, escapando à sua compreensão, apenas gera uma miríade de desconfianças (algumas delas talvez coerentes, presume-se, mas não temos como prova-las, já que também somos lançados na incerteza, feito Bentinho ao desconfiar de Capitu). Orr desconfia de Trause e de uma suposta ligação afetiva dele com Grace. Grace passa uma noite fora, sem avisar (a noite em que o apartamento dos dois é invadido por alguém e as joias e os objetos de valor afetivo de Grace foram roubados ou destruídos) e, em lampejos de agressividade imprevista, queixa-se sutilmente de Orr, para logo em seguida pedir desculpas e a compreensão de Orr (mas, ao pedir compreensão, acaba deixando em suspenso se ela porta ou não algum segredo, alimentando ainda mais a paranoia de Orr). Grace também comenta sobre uma possível gravidez, da qual nós e Orr não sabemos se ela já sabia disso há mais tempo. Orr insiste em ter o filho, mas Grace oscila, sem demonstrar muito bem o porquê.

Voltemos, contudo, à nossa cripta (e é nossa também?).

Lembremos que, em termos sonoros, Orr pode ser escutado como hors em francês, que significa “fora”. De fato, esse encriptamento se dá fora de Orr, no quarto hermeticamente fechado de Bowen, seu túmulo.

Lembremos o que nos diz Derrida:

Não tendo sido levado de volta para o interior do "self" e digerido, assimilado como em todo luto "normal", o objeto morto permanece vivo como um morto-vivo, formando um abcesso em um ponto específico do self. .Ele tem seu lugar tal como uma cripta em um cemitério ou em um templo, rodeado por muros e todo o restante. O objeto morto é incorporado nessa cripta, o termo "incorporado" assinalando precisamente que alguém falhou ao digerí-lo ou ao assimilá-lo totalmente, de maneira que permanece ali, formando um bolso no corpo em luto. O morto incorporado que não foi realmente levado a tomar o lugar de alguém continua aí alojado como alguma outra coisa e agindo como ventríloquo através do vivo. (1988, pp. 57-8).

Mas o bunker faz parte de Orr, pois ele é materialização de suas ideias. O caderno é um local-instrumento de articulação de experiências, um bloco-mágico de fazer estórias. Podemos imaginar que Orr recorre ao caderno como uma espécie muito potente de meio maleável para elaborar suas imagos traumáticas, conforme os termos dados pelo psicanalista francês René Roussillon (2013) a essas falhas traumáticas dos objetos, na esteira do pensamento de Marion Milner. O caderno, em sua brancura e abertura fundantes, permite a inscrição de qual elemento for da subjetividade do escritor. Orr parece fazer dele seu 
oráculo $^{43}$. Porém, como o título do livro sugere, esse oráculo possui sua noite, que poderia nos remeter tanto ao que, nele, não há mais de visibilidade - o delineamento de um limite (noite) intransponível ao oráculo -, como também ao seu ocaso, seu fim. O oráculo, em Noite do oráculo, possui propriedades místicas, pressagiadoras, mas também é um cárcere, uma cela, principalmente para aqueles que querem fazer da existência, numa compulsão à repetição interminável, uma fonte de mensagens enigmáticas e disparatadas, à beira do sem sentido. Em resposta a esse caos, e principalmente em resposta às interrupções traumáticas do existir, busca-se, a todo custo, enredar e amortalhar essa vida com os seus fios soltos, e, talvez, compondo um texto-tecido, é verdade. É o que Orr parece fazer desde o início, aceitando as estórias que lhe são sugeridas (por Trause, por exemplo) como pistas para uma revelação oracular (e sempre oblíqua) de si mesmo.

Ed Victory parece também oscilar e ser uma figura contraditória em seu luto, ainda que seja um sobrevivente que se propõe a erguer um monumento aos mortos e aos vivos, portanto mantendo-se voltado tanto para o passado, em fidelidade melancólica, quanto ao presente, em abertura para o porvir. Antes de tudo, seu monumento, na verdade, não é um monumento, já que, abaixo da terra, submerso, próximo à coisa heideggeriana, ele não se mostra à visitação e ao mundo. Ele não é para ser compartilhado e servir de suporte para as recriações, rememorações e religações intersubjetivas, condição fundamental, como nos fala Figueiredo (2014), para o restabelecimento de subjetividades traumatizadas e fraturadas. O memorial de Ed, chamemo-lo dessa forma, pode ser um objeto testemunhal (Hirsh, 2012), mas seu uso não é compartilhado, salvo por Nick. Assim, o arquivo de Ed volta-se para dentro, formando essa espécie de cripta no limiar entre a terra e os mortos (e Nick morrerá lá, numa morte que não presenciaremos como leitores). Tal cripta, então, como nas primeiras criptas cristãs, é incrustrada na terra, funcionando como ponto de contato com o mundo ctônico, um verdadeiro portal de acesso ao mundo dos mortos. As criptas não são, portanto, totalmente fechadas, mas sim porosas, até para que os fantasmas possam emergir e circular. Porém, é possível escrever sobre a cripta, e talvez nesse “desencriptamento” mágico, o reencontro com muitos fantasmas seja possível.

Segundo Gabriele Schwab (2010), seguindo Nicholas Abraham e Maria Torok, as criptas, em termos psíquicos (e transgeracionais), são lugares de sepultamento no self, para manter um cadáver vivo. Como efeitos de lutos fracassados, elas recobrem o trauma e a parte da realidade ligada a ele. Sendo assim, e pelo que dissemos antes, não estaria Auster

\footnotetext{
${ }^{43}$ E Orr também é escutado na pronúncia em inglês de oráculo (oracle)
} 
recorrentemente escrevendo sobre a cripta do pai? Não estaria ele escrevendo o epitáfio do pai, escrita de epitáfio que se multiplica em textos e mais textos para um morto?...

Retornemos, com temor, à cripta de Nick Bowen, que espera seu Godot que nunca chegará.

O que mais sentimos, na leitura, é vertigem de uma queda claustrofóbica, uma queda para um confinamento apertado, estreito, sem saída. E Auster reedita essa cena não só nesse livro como em outros. Ao se deixarem ser aprendidos num claustro intransponível, os personagens de Auster parecem refazer a trajetória "mágica”, e talvez invertida, de Harry Houdini, o mágico, mas numa versão fracassada.

O psicanalista Adam Phillips (2001), no seu interessante ensaio sobre Houdini (Houdini's Box: The art of Escape) nos conduziu, em segredo, até aqui. Houdini, o mágico que encantou multidões com suas fugas de correntes, camisas de força, algemas, caixões de água etc., era um ilusionista que, além das mágicas convencionais, especializou-se, de forma fenomenal, na arte de escapar dos maiores e sempre mais desafiadores mecanismos de confinamento (que eram por ele mesmo inventados ou então emprestados dos principais agentes repressores da época: a polícia e o manicômio). Para atrair a massa, como bom precursor dos grandes shows de entretenimento em massa, Houdini precisava incitar na multidão algo que fosse capaz de capturar a atenção da mesma. Para isso, Houdini precisava desafiar e superar, em proezas sempre únicas, o que a multidão mais temia: a morte. Então, quando se deixava ser aprisionado por policiais com suas algemas ou pelos agentes de saúde mental e suas camisas de força, ou então quando se deixava dependurar de ponta cabeça e ser acorrentado em reservatórios de água hermeticamente selados, correndo o risco de morrer se não conseguisse se desvencilhar em tempo, o que ele produzia era uma experiência de confinamento, não aconselhável ao resto dos mortais, sob pena de morte ou enlouquecimento, com a posterior libertação, excitante, de sua condição anterior. Phillips demonstra de maneira muito elegante o quanto isso elaborava não só as questões pessoais de Houdini, mas também as fantasias e angústias inconscientes produzidas por uma sociedade disciplinar e que força a assimilação a todo custo. Seu pai, contudo, judeu emigrado, não conseguira se assimilar adequadamente à cultura e sociedade americanas. Intelectual e advogado, não conseguiu o sucesso que esperava, pelo que Houdini o vinga, a posteriori. Houdini se deixa prender (assimilar) para sempre melhor escapar, em maior espetáculo. Phillips conta como o que assombrava a mente de Houdini eram as imagens e lembranças de pessoas que não conseguiam escapar (ele tinha interesse por relatos de torturas chinesas, por exemplo). Houdini, então, infligia a si mesmo uma tortura como maneira de descobrir como sair ileso e 
vivo dela. O que também nos interessa bastante era o fato de que o mágico, apesar da sua arte estar no limiar da mistificação, era um devoto perseguidor dos falsos-mágicos, aqueles que se diziam comunicar com os mortos. Houdini, o mágico, empreendeu uma cruzada contra os médiuns espíritas, que se diziam mensageiros dos espíritos ou então simulavam, segundo, Houdini, uma farsa. Eram farsantes porque não diziam que o que faziam era uma mágica, um truque, e não uma “real” comunicação com os mortos. Curiosa assombração de Houdini pelos falsos espíritos (haveria verdadeiros?).

Ora, se Houdini se prende cada vez mais para se soltar e saltar com maior destreza, em Auster, e em nosso livro em questão especificamente, os personagens, quase de maneira inversa, saltam e se precipitam para a existência, mas para melhor se deixarem prender, encriptando-se.

Orr, então, voltemos a ele, após encriptar Bowen, acelera sua fuga para fora do livro, mas não sem antes reencontrar outras tragédias.

Incapaz (ou se fazendo incapaz) de tirar Bowen de seu túmulo literário, Orr agita-se. Começa a desconfiar de suas memórias e percepções. Para num café para ler os jornais do dia. Após ler notícias fugazes sobre esportes, topa com uma notícia grotesca, “outro despacho das entranhas do inferno” (Auster, 2003, p. 107): um bebê rejeitado, nascido numa privada. Uma conhecida prostituta e drogada em crack, Kisha White, tinha dado à luz um bebê morto, e depois o jogou numa lata de lixo. Ela estava vendendo seu corpo a um homem na madrugada, entre um uso de pedra e outro. Quando entrou no banheiro para fumar novamente, sentiu a bolsa romper e algo sair. Sem notar que tinha dado à luz, depois de vinte minutos notara o bebê morto na privada. Embrulhou no jornal e jogou em uma lata no lixo.

Quando Orr termina de ler o artigo, disse a sim mesmo:

É a pior história que li na minha vida. Já era bem difícil absorver a informação sobre o bebê, mas quando chegava ao incidente das punhaladas no quarto parágrafo, entendi que estava lendo uma história sobre o fim da humanidade, que aquele quarto no Bronx era o ponto exato da terra onde a vida humana havia perdido seu sentido. Fiquei longos momentos parado, tentando recuperar o fôlego, tentando parar de tremer, e então li o artigo de novo. Dessa vez, meus olhos se encheram de lágrimas. Lágrimas tão súbitas, tão inesperadas que imediatamente cobri o rosto com as mãos para ter certeza de que ninguém ia ver. (Ibid.; itálicos do autor). 
Numa coreografia de mãos, que se erguem param esconder o rosto, os olhos e as lágrimas, para não ser visto, mas também para não ver o que ele tinha já visto - o fim da humanidade -, Orr parece chorar deslocadamente, como tivera feito Auster. Não que a cena, em si mesma totalmente trágica, não fosse capaz de nos destroçar e a Orr, mas sim porque, ao escrever sobre Dachau e seus trinta mil mortos, e sobre a criança morta que toma leite, talvez seja também este choro que esteja sendo extravasado, inaugurando e fazendo eclodir um lençol freático de lágrimas (e, como estamos num oráculo, de lágrimas passadas e futuras). Essa corrente de lágrimas e choros, talvez nunca chorados porque não houve túmulos sobre os quais pudessem ser pranteados esses mortos, essa corrente subterrânea atravessa a História, os locais, as épocas, as nações e os personagens. Não sabemos onde a corrente começa, pois ela se religa a outros lençóis de água. Não sabemos onde termina, pois ela lançará suas águas quiméricas sobre os herdeiros.

Poderíamos imaginar que, ao chorar pela humanidade que fracassou na figura da viciada em crack, deslocando o choro do bebê morto que nunca mais bebeu seu leite, Orr esteja tentando, em luta titânica, criar um espaço de triangulação interno para o que invade e irrompe como uma ligação não-simbólica, tentando criar um terceiro dentro de si. Algo é passado, contagiado, provocando ligação e repetição, com a esperança furtiva e trêmula de que alguma simbolização aconteça (segundo Roussillon, a compulsão a repetir, quando encontra um objeto responsivo, torna-se compulsão a simbolizar). Nessa hesitação entre ligar e chorar, e não ligar e morrer internamente, Orr vive o seu drama.

Supomos, também, que Ed Victory tenha sido intoxicado com o morticínio, como um pulmão que não tem mais espaço para o que começa a necrosar dentro dele em forma de catarro e fumaça. Seu arquivo, um arquivo do trauma, é composto de listas telefônicas, como se fossem cadernos ou palimpsestos de números, de números tatuados, milhares, milhões. Um palimpsesto de morte, encadernado, num amargo e mortal "mil-folhas”, impossível de engolir.

Essa transmissão dos números, das vidas reduzidas à estatística da morte, tem um impacto tão profundo que, em muitos relatos de filhos e descendentes de sobreviventes, esses herdeiros do segredo intransponível mostram como eles se viram diante de números muitas vezes indecifráveis, o que, para muitos também, fora reforçado pela vergonha e/ou recusa dos pais ou avós contarem o que aquilo significava. Nessa transmissão transgeracional do traumático, o que não é simbolizado, o que é transmitido em segredo, mesmo quando abertamente comentado, pode vir a ser até encriptado no corpo. Um relato disso, citado por Hirsch (2012), é bastante pungente a esse respeito. Trata-se do relato de Anne Karpf, uma filha de uma sobrevivente de Auschwitz, e seus sintomas ao redor de marcas na pele. Anne, 
durante a vida adulta, sofrera de eczemas e de coceiras terríveis, que se espalhavam pelo corpo.

\begin{abstract}
Eu gostaria de me livrar da minha pele, descascá-la como se faz com uma roupa engomada deixada pendurada e, ao final, despojada como fosse se esconder. Minha pele não parecia apta para manter o que estivesse dentro dela. Após anos no processo de arranhá-la, um amigo próximo me perguntou se o local do meu antebraço que eu repetidamente machucava seria o mesmo local do braço de minha mãe que havia sido tatuado no campo de concentração. Eu estava surpresa, pois nunca isso me ocorreu. Mas eu não pude acreditar que o inconsciente pudesse ser responsável por tal simbolismo cru, do tipo encontrável em filmes feitos para a televisão. Parecia, na verdade, uma tentativa básica para dotar minha própria e frágil epiderme da desolação com sua histórica gravidade e dignificá-la em referência à da minha própria mãe (eu permaneço não convencida disso). (Karpf, apud Hirsh, 2012, p. 84).
\end{abstract}

Comentaremos, no próximo capítulo, essa modalidade de transmissão traumática, comparando-a a outras formas de religação da ancestralidade.

O que nos interessa, no momento, é apontar que Orr/Nick/Ed são contaminados por dores cujas origens se escondem atrás de névoa. Mas a indecisão quanto à origem pode ser, justamente, um efeito de uma condição traumática que nunca se deixa perscrutar totalmente. Se seguirmos Melanie Klein, quando afirma que uma perda traumática reativará, em cadeia, todas as outras perdas e lutos, temos aí um possível modelo para pensar esse sequenciamento de catástrofes (maiores ou menores). Novamente, nos inspiramos na máxima derridiana: no início era a repetição!

Mas isso não implica um estreitamento nem uma relativização dos eventos traumáticos que, apesar disso, sempre são singulares e únicos. Num plano cultural, também não implica a relativização do trauma do Holocausto em detrimento de outros acontecimentos traumáticos pessoais ou coletivos. Apostamos, aqui, que Auster nos mostra a possibilidade de uma memória multidirecional, para usarmos o conceito de Michael Rothberg (2009). Essa memória não compete com outras. Pelo contrário, ela abre a possibilidade de um contágio em múltiplas direções, permitindo, inclusive, que eventos traumáticos possam ser elaborados a partir de outros eventos. Rothberg sugere, como outros também fizeram (cf. Luckhurst, 2008), que essas memórias, funcionando inclusive como uma tela de proteção, permitiriam a projeção e a religação de outras memórias (inclusive traumáticas).

Assim, como Schwab (2010) também demonstrou, alguns eventos traumáticos podem ser elaborados em outras narrativas que contam seus próprios traumas. O exemplo crucial, no relato de Schwab, é a reelaboração da culpa germânica após a Segunda Guerra Mundial, em doses pequenas e circunscritas, mas ainda assim possíveis, em eventos distanciados no tempo, 
como a Guerra do Vietnã. Muitos jovens estudantes, que cresceram ouvindo as narrativasfetiche (como Schwab denomina), que funcionavam como uma espécie de cobertura contra os traumas (não diziam nada, ou diziam tudo, mas de maneira desafetada), conseguiram, em alguma medida, lidar com a culpa e a responsabilidade de uma violência das quais foram herdeiros involuntários (embora o trabalho ficou muito aquém do que era exigido. Há muito a se enlutar e do que se culpabilizar).

Orr, em hesitação, elabora sua culpa, embora, no livro, não saibamos qual dos traumas é o original (aos quais se somarão outros).

Após a leitura do recorte de jornal sobre a viciada em crack, Orr, tendo chegado ao final do mundo, do humano, salta até o final do seu caderno, e cola a tira de jornal contendo a reportagem na contracapa traseira do caderno, como se para lembrá-lo que é daí (um “daí” que, como supusemos, é múltiplo e multifatorial) que ele precisará recomeçar.

Escreve a partir do final do caderno, então, recuando para o começo. Esse gesto, insólito como pode parecer, nos remete - em nossa leitura que busca não ser paranoica, mas sim reparadora - à escrita regressa do Hebraico, da direita para esquerda. É como se Orr/Auster reassumisse, também quase em segredo, a identidade judaica ${ }^{44}$. Essa volta para o centro, um centro imaginário, culminará no esgotamento de todos os recursos defensivos de Orr perante o inefável, o insondável e o não elaborável.

Não conseguindo mais conter seu desespero diante das falas evasivas de Grace quanto às suas saídas e quanto à sua gravidez (agora confirmada), Orr desconfia ainda mais de seus (supostos) segredos. Orr tenta invadir e penetrar a mente de Grace para lhe roubar os segredos, mas é Grace que, de sua hospitalidade ao estranho e ao estrangeiro, é capaz de sonhar Orr. Num sonho que ela teve na noite anterior, narra para Orr que sonhara com os dois numa cena altamente excitada e erótica num quarto dentro de uma casa velha, um quarto que, diferente do quarto que Bowen foi deixado às traças literárias, continha todo o conforto e luxo que faltava nos sóbrios quartos de Auster. Perto estavam estantes metálicas, cheias de livros, e todas continham o nome de Sidney Orr em suas lombadas. Grace, ainda, sonha que, após fazerem amor, eles despencam no sono e, quando ela acorda, vê Orr tentando abrir a maçaneta da porta, que parecia trancada, trancando-os ali.

\footnotetext{
${ }^{44}$ Vale constar que Orr não menciona nenhum laço de parentesco, salvo sua esposa. Orr, ao que parece, e não podemos concluir muita coisa, não traz as marcas da família, como se fosse um órfão, um desligado da hereditariedade: não menciona pai, mãe, irmãos, tios, avós etc. Seu único objeto afetivo que quase se aproxima de um pai é Trause. Retomaremos essa dimensão de orfandade posteriormente, remetendo-nos a uma figura mítica que espera seu pai, como Telêmaco à espera e depois à caça de Ulisses, por exemplo.
} 
Não sabemos, contudo, se é Grace que, com suas faculdades inefáveis, consegue se imiscuir na mente de Orr, sonhando o sonho de Orr, mas de uma maneira mais erótica e libidinizada, ou se estamos diante de outro mistério. Talvez ambos sejam sombras nos sonhos de outra pessoa, como Orr desconfiava de si mesmo. Talvez sejam sonhos de outro narrador. Se assim for, a ligação e comunicação telepática entre os dois (a comunicação entre as mônadas) se dá por um intermédio de um terceiro, e talvez por compartilharem a mesma substância dele. Ou então Grace é versão erótica, saborosa, da cripta de Orr. Talvez Grace revele o que Orr nunca ousou reconhecer: que abriga cadáveres “saborosos”. Mistérios...

Fato é que Grace será inscrita - e encriptada também - nas malhas paranoicas de leitura de mundo de Orr. Nesse meio tempo, o apartamento dos dois tinha sido arrombado e os objetos de valores históricos e afetivos de Grace, roubados. Como uma modalidade de assassinato simbólico (e a foto de Grace também fora rasgada, para dar margem a essa leitura), a desumanização de uma pessoa começa quando as vestes simbólicas delas começam a ser retiradas, como Hannah Arendt (1951) pensara em relação ao inicio do morticínio nazista perpetrado contra os judeus. As vestes simbólicas de Grace são seus objetos culturais: quadros, pinturas, livros recebidos etc. Um em especial, que era presente de Trause, era uma litografia de van Velde, artista plástico favorito de Beckett. Numa carta de Beckett comentando van Velde, lia-se o seguinte: “O que digo é que van Velde é... o primeiro a admitir que ser artista é fracassar, como ninguém mais ousa fracassar, o fracasso é o seu mundo.” (citado em Auster, 2003, p. 168, itálicos no original).

Mas o artista fracasse em que?

Em primeiro lugar, fracassa em redimir os mortos e o mundo. Em segundo lugar, fracassa em representar as catástrofes da sua época. Em terceiro, fracassa, conscientemente, em representar essas mesmas catástrofes, mas agora como imperativo ético (não há triunfo possível da arte depois de Auschwitz).

Orr, então, caminha para seu fracasso, para o fracasso de escrever sua estória.

Decide, então, inscrever Grace em sua trama literária (Grace que, até então, permanecera fora do livro, na vida "real”).

Refaz o caminho do detetive atrás do assassino e do corpo. Reconstrói a história de Grace. Suas evasivas e saídas eram para encontrar Trause, com quem tinha um caso, muito antes de conhecer Orr. Como Trause era mais velho e amigo da sua família, o romance era dado a complicações. Trause hesitava em continuar com ela, o que a fazia sofrer. Decide-se, então, largar de vez Trause e aceitar os flertes de Orr, que recém conhecera na empresa. Trause estimula, mas está sempre por perto, e torna-se amigo (rival) de Orr. 
Eis então que acontece a "catástrofe”, assim nomeada por Orr. Ele cai de uma escada numa estação de metrô. Quebra dois ossos, fratura órgãos internos e é mantido por quatro meses no hospital (possivelmente em coma).

Quando Orr volta novamente aos vivos, após ter visitado o reino de Hades, isso tornase um espanto para os médicos, bem como para Grace e Trause, que, diante da incerteza da condição de Orr, reataram. A situação triangular se complica. Grace engravida, mas não sabe de quem é o filho. Hesita em contar para Orr que está grávida, e depois, se vai ter o filho. Passa uma noite fora de casa. Orr suspeita que ela foi rever Trause, para decidir finalmente o rumo de sua vida. Grace perde a graça que Orr lhe conferia. Torna-se uma portadora de segredos sujos, não confiável. Mas Grace fará um esforço, fará um salto de fé: acreditará que o bebê é de Orr e apagará as dúvidas (como Nick apagando o passado). Quer continuar casada com Orr. Seu salto de pura fé toca Orr.

O episódio de Trause está encerrado e, enquanto continuar querendo ficar casada comigo, nunca contarei a ela nem uma palavra do que acabo de escrever no caderno azul. Não sei se é fato ou ficção, mas no fim das contas não importa. Contanto que Grace me queira, o passado não tem importância. (Auster, 2003, p. 203)

Orr também dá seu salto de fé cego kierkegaardiano, como Abrahão diante do chamado do Pai. O salto é para fora do livro, para a "realidade”. Orr faz o luto do caderno, do perigoso bloco-mágico de profecias.

Colocou a tampa da caneta de volta.

Arrancou uma a uma as páginas do caderno azul e rasgou em pedacinhos. Colocou tudo num saco e amarrou com um nó. Assim como bebê jogado no lixo pela mãe viciada, Orr enterra (talvez em cerimônia fúnebre laica) seu caderno numa lata de lixo, embaixo de um maço de rosas murchas.

A maior tragédia, no entanto, ainda está por vir. Como se, desde o adiamento no início do livro, nessa postergação e diferimento constantes, a catástrofe “central” (e, pelo que já pudemos ver até aqui, supomos que não há mais centralidade possível) precisasse de toda essa narrativa parar ser desvelada.

Jacob, o filho renegado de Trause, viciado em heroína e em dívida (fora ele que arrombara e assassinara simbolicamente Grace) visita novamente o casal, mas agora alucinado, com a fúria nos olhos. Jacob, umas das quimeras do livro, exige dinheiro do casal e, quando recusado, salta em direção a Grace, espancando-a. Grace perde o filho. Orr não conseguira deter o diabo. 
A veia de Trause estoura finalmente e ele falece. Grace, no hospital, recebe a notícia da perda do filho. Orr, no enterro de Trause, constata que a palavra Deus não fora mencionada nenhuma vez na cerimônia. Orr retorna a Grace, seu salto final...

O livro é escrito vinte anos depois desses acontecimentos. A primeira leitura, mais óbvia, nos faz encontrar aí, nessa origem tardia, o centro de irradiação das demais catástrofes e narrações perlaborativas. No entanto, Orr é suspeito. Orr rasgara o caderno azul e, após vinte anos, reconta toda a história novamente. Orr ainda sofre de sua visão deturpada (simbólica e real)? Ao reconstruir os fatos, ele, como dono do oráculo, não caminha em ambas as direções temporais, desfazendo o tempo linear e, com isso, o colapsando? Um fantasma que atravessa paredes temporais e enterra pessoas, mas ainda assim também se sente como o refém num sonho de alguém. Orr pode recompor a história na ordem labiríntica que quiser, e nunca saberemos.

O livro, com uma trama labiríntica, recheada de elementos duplos e espectrais, interdita conclusões apressadas, ou talvez qualquer conclusão.

Como Dédalo, esse artífice dos labirintos, e Ícaro, seu filho, cujas asas lhe foram dadas pelo seu pai, Orr salta rumo ao seu voo, talvez levando um pai desconhecido junto consigo. Talvez os Auster, pai e filho, voem um com a ajuda do outro para fora do labirinto.

Didier Anzieu (1981) comenta acerca da noção de decolagem, ou seja, que, diante de perdas sofridas, a criatividade precisará ser acionada para realizar o trabalho de luto, como se numa decolagem rumo a outro lugar, des-colando e decolando, alçando voo. Grace é essa figura da transcendência, mas uma Grace liberta - na medida do possível - do que ainda a aprisiona numa força gravitacional confinante. É por escrever, rasgar o caderno e reescrever sua história que Orr, perlaborando-a, parece tentar saltar rumo ao seu futuro. Escrever é perigoso. E nós recebemos o livro, e o reescrevemos... 


\section{Do desastre às constelações}

O que é seguir um fantasma? E se isso significasse ser seguido por ele, sempre, perseguido, talvez em razão da caçada que lhe fazemos? Aí também o que parece na dianteira, o porvir, revém antecipadamente: do passado, por trás. Jacques Derrida - Espectros de Marx.

Receber o livro e reescrevê-lo. Perseguir um fantasma e descobrir inúmeros outros. De um pai que se esquivou da existência aos sofrimentos dos judeus no Holocausto e dos pais que se ajoelham no túmulo de seus filhos mortos, uma torrente de dor, trauma e lágrimas (recolhidas ou inventadas) invade nossa leitura e a encharca. Uma escrita úmida, umidificada pelos choros de figuras ancestrais e espectrais. Mas uma escrita que poderia, em sua hospitalidade aos textos de Paul Auster, também ser chamada de úmida porque se deixa invadir - pelos poros - pelos rastros, imagens, fantasmas e memórias do escritor novaiorquino, sem opor muita resistência, ou, pelo menos, deixando as resistências emergirem naturalmente, como que a desenhar uma cor e um estilo possíveis a partir da umidificação pelo texto de Auster. Umidade como porosidade, abertura não alérgica, hospitalidade, contaminação pelo que é outro, fertilidade, deixar o outro habitar o texto ao ponto da (quase) indistinção.

A questão do método de leitura, então, ganha matizes éticas, e não somente técnicas. Ética da leitura enquanto ética da hospitalidade, do acolhimento e da resposta ao outro. Leitura enquanto habitação de uma morada, instalando-se na obra para, daí, uma experiência de hospedagem se dar. Não se sabe quem é o hóspede e quem é o hospedeiro, é verdade. Nessa indefinição acerca desse host (hóspede ou hospedeiro) joga-se toda a possibilidade de um encontro não controlável, cuja economia, paradoxalmente, está sempre pondo em risco as leis da casa, do oikos. A demarcação das fronteiras, traçando-as e retraçando-as, como que a delimitar um dentro e um fora claramente opostos e discerníveis, corre sempre o risco de ser desmantelada, ou então, reafirmada, em desespero. De onde vem o grito? Segundo Monique Schneider, em sua leitura de Freud, a presença desse nebenmensch (ser-próximo) no pensamento inaugural freudiano (e no nascimento e inauguração de todo pensamento e psiquismo) torna-se semente de loucura, dada a incerteza da proveniência do grito de desamparo (vem de mim ou do outro?). Nessa região suspensa, então, o parapeito conceitual é erguido. As fortificações são construídas. Derrida nos alerta desde suas leituras de Platão que 
os rituais de expurgação, a cerimônia do phármakos, sempre se dão nessa fronteira entre dentro e fora, intra muros/extra muros (Derrida, 1972).

Em recusa a isso, retomamos uma ética e um pensamento úmidos, conforme o filósofo brasileiro Rafael Haddock-Lobo (2011) recolhe e resgata esse termo - o úmido - de Francis Bacon, dando-lhe um caráter positivo e afirmativo.

Para o pai do pensamento científico, todavia, o conceito de úmido trazia, como já esboçamos na apresentação da tese, uma espécie de indefinição atávica, a meio-caminho entre o seco e o molhado, como que sofrendo de uma indeterminação essencial, causa e origem da repulsa do empirista inglês e, segundo a extensão que lhe dá Haddock-Lobo, na esteira da Derrida, de toda filosofia sistematizadora que busca abarcar, prender e sufocar tudo o que é o seu outro.

Tome-se como exemplo a palavra úmido e enumerem-se os significados que pode assumir. Descobriremos que esta palavra úmido compila notas confusas de operações diversas que nada têm em comum ou que são irredutíveis. Significa, com efeito, tudo o que se expande facilmente em torno de outro corpo; tudo que é em si mesmo indeterminável e não pode ter consistência; tudo o que facilmente se divide e se dispersa; tudo o que se une e se junta facilmente; tudo o que facilmente adere a um corpo e molha; tudo o que se reduz a líquido, se antes era sólido. (Bacon apud Haddock-Lobo, 2011, p. 48).

Diante desse úmido, desse elemento indecidível, e de outros tantos indecidíveis, a filosofia reagiu e reage buscando conjurá-los, na acepção de eliminação do elemento espectral via um certo tipo de exorcismo, mesmo que laico (embora os motivos teológicos sempre espreitaram a filosofia e a literatura). Expulsa-se o híbrido, talvez uma quimera conceitual, por intermédio da nomeação, da sistematização, do enquadramento e de outros tantos recursos e expedientes retóricos e não retóricos (e sabemos quantos expedientes violentos foram e são postos em movimento para “descontaminar” e gerar as purezas sonhadas). Não só a filosofia, desde seus primórdios, mas também a Modernidade exerceu essa modalidade de exorcismo, conjurando os híbridos que ela mesma desde seu início seguiu produzindo, conforme nos ensinara Zygmunt Bauman (1999).

A partir desse horror ao úmido, ao que escorrega por entre os dedos, ou ao que se adere na pele e se torna viscoso ${ }^{45}$, a Modernidade, muito temerosa, reagiu e trabalhou

\footnotetext{
${ }^{45} \mathrm{E}$ a imagem do úmido - disso que invade, adere, se espraia e é incerto - pode traduzir também uma das imagens do estrangeiro dentro de casa, isto é, daquele que causa hesitação, indefinição e mal-estar, justamente por não se saber como reagir e responder à sua imprevisibilidade e sua alteridade. As regras e leis da hospitalidade, conforme lia Derrida a partir de Lévinas, se, por um lado, comandam uma abertura infinita ao
} 
exercendo e pondo à prova seus sistemas de classificação e ordenamento do mundo, aterrando, expulsando e expurgando tudo aquilo que abalasse suas definições e pusesse em xeque seu projeto, mas apenas para gerar mais híbridos ainda. Um forte medo paranoico do contágio sempre acompanhou esse projeto. Os inclassificáveis, como bodes-expiatórios para a fúria, terror e temor dos projetistas da Modernidade, quase sempre recebiam alguma marca para que se pudesse identificá-los de longe, classificá-los e, com isso, saber como proceder com eles.

Dominck LaCapra, nesse sentido, comenta que a Estrela de David costurada ou afixada na roupa, quando das perseguições aos judeus, também servia - além da identificação segregacionista e sinal de todo o morticínio que estava por vir - como um alerta a indicar o fantasiado perigo de contato e contágio. Como se sabe, também nos meios mais intelectualizados e ditos culturais esse mecanismo de evitação (para dizer o mínimo) cumpria o papel de alertar para esse “perigo” de contágio e de conspurcação da “cultura germânica”:

... Os judeus eram sujeitos a muitas restrições, inclusive mesmo em seus empreendimentos artísticos, tal como serem proibidos de representar ou mesmo ouvir o que os nazistas consideravam como autêntica música germânica. Eles eram também impedidos de se apresentar para audiências germânicas ou assistir a performances teatrais, já que a presença judia profanaria, sujaria e colocaria em perigo o "espírito Germânico". A razão de costurar a estrela de Davi nas roupas dos judeus era para permitir que outros evitassem a contaminação por contato com os mesmos. (LaCapra, 2013, p.128).

Aqui, uma loucura paranoica que se tornou assassina, mas também engendrada e tornada possível por essa gigantesca máquina administrativa Moderna.

Ora, um encontro como uma obra de arte que seguisse um sistemático protocolo de leitura, seguindo também à risca essa versão moderna de ordenamento e classificação, estaria assombrada por alguns desses fantasmas, correria os mesmos riscos e talvez seria signo desse mesmo medo de contágio frente a uma aproximação excessiva.

Além disso, os esquemas prévios de leitura poderiam funcionar, também, como uma espécie de anteparo reassegurador perante o desconhecido e o incerto, como um roteiro a mapear o terreno minado em que entraríamos (como se fosse possível antecipar o que tal campo reservaria a nós). Não sabendo como prosseguir ou como receber uma obra, lançar-seia mão de ferramentas, modelos e critérios que traduziriam mais o medo do desconhecido

estrangeiro, um dizer sim incondicional, por outro, também servem para regular e modular essa presença, exigindo dela, inclusive, a contrapartida desse acolhimento, ou seja, exigindo que o estrangeiro se comporte, fale a língua e obedeça às leis daquele que recebe. (Cf. Derrida, 2003) 
(e/ou a tentativa de dominá-lo) do que a possibilidade da obra ganhar voz e falar por si mesma.

Não estivemos longe desse protocolo de leitura, no início, antes de iniciar a presente tese (ou já tendo iniciado). Este protocolo estaria calcado em alguma forma de crítica e anteparo conceitual externo à obra, sempre importados de outras áreas e disciplinas, mas não com vistas a promover uma experiência de leitura não alérgica, mas sim para aplicar à obra literária um esquema de leitura e de explicação quase sempre exteriores a ela. Leitura paranoica talvez, e que, se tornada rígida, quase sempre é reducionista. Essa leitura, que parte de fora da obra, mimetizando, talvez, os procedimentos, o vocabulário e os métodos de outras ciências, intenciona tomar a obra como um exemplar do que a teoria quer comprovar. Estereotipia de um (ou mais de um) método tornado universal, indiferente aos seus contextos e objetos. Vale para nós, aqui, as provocações de Paul Feyerabend (1975), filósofo da ciência, que questionava essa pretensão e ditadura da uma generalização indiscriminada de qualquer suposto método, “científico” ou não, criticando a ideologia por detrás desses mitos metodológicos. Seu anarquismo epistemológico, ao contrário, “contra o método”, advogava uma liberdade inaudita de descrição e redescrição para toda e qualquer modalidade narrativa, segundo os próprios interesses dessas narrativas (explicativos, comunicativos, expressivos, emancipatórios...), para tomarmos emprestados os termos de Habermas.

Nossa leitura, assim, buscou evitar aplicar e inserir, de antemão, qualquer sistema de compreensão teórico que engolfasse a obra e ditasse os rumos da leitura, como a sociologia e, principalmente (porque nos sendo mais próxima) a psicanálise. Defendemos que, então, não fizemos, (ou tentamos não fazer) nem psicanálise aplicada nem, muito menos, crítica literária. A exigência que despontava era, antes, de que, caso alguma teoria se aproximasse da literatura, a própria teoria precisaria se (deixar) tornar, em alguma medida, literária. A teoria, dessa forma, se poetiza e assume, mais abertamente e de maneira menos pudica, sua condição metaforizante.

Por outro lado, nossa leitura tentou aguçar seus ouvidos (e não sua visão somente) para escutar os gritos silenciosos que poderiam advir do confronto com o texto. Leitura cega em grande medida, e de cego. E retomaremos algumas vezes essa dimensão de cegueira que queremos conferir, na esteira de Derrida, à nossa leitura, bem como aos personagens e à obra de Auster. Ainda que o próprio texto nos tenha feito produzir uma profusão de imagens, em trilhas associativas não controladas, mas seguindo as obras de perto, a questão da visão interrompida, talvez por uma mão que lhe encubra, ou por um pano, uma bandagem amarrada aos olhos (o próprio texto-tecido), adquire uma dimensão ética fundamental. Escrita de cego, 
tateando no escuro, tentando se antecipar ao não antecipável, bordejando abismos, e por isso mesmo correndo sempre o risco de se precipitar e despencar. Escrita que, também se tornando um pouco cega ao que de mais evidente se mostra no texto, não deixa de se voltar para ouvir ruídos, murmúrios e choros em fragmentos, ruínas, traços e detalhes dispersos. Uma escrita e leitura, portanto, nos limiares da visão, da vista, e talvez contra mesmo essa hierarquia da visão, contra o que fora os fundamentos e o primado de certa fenomenologia, e talvez de grande parte da metafísica ocidental.

Os signos dessa oscilação da visão em nossos textos escolhidos são muitos. Podemos elencar, entre outros, a carência de visão ou então seu excesso, ao ponto de se ficar cego, advindos do choque traumático, que, disruptivo, desorganiza as próprias condições de percepção do mundo e da realidade: fica-se cego porque se viu demais. Ou fica-se cego para ver melhor em outro plano, ou mais longe, como o personagem do livro A noite do oráculo, que, após uma explosão, torna-se cego e, profeticamente, enxerga o futuro; aqui, fica-se cego para poder ascender a outro patamar de visão, para enxergar mais.

Assim como nossos personagens, e talvez o próprio Paul Auster, deixamo-nos ficar cegos um pouco para poder ouvir e tatear melhor no escuro, portando nosso cajado-caneta em nossos rascunhos, redesenhando o texto de Auster em caderno, ou então na tela de um computador (e aí são os dedos que enxergam no lugar dos olhos).

Em contraste à leitura paranoica, na qual mesmo os personagens de Auster recaíam constantemente (inclusive A., a versão em terceira pessoa de Auster ${ }^{46}$ ), sonhamos com uma outra leitura: uma leitura reparadora. Esta não fecha o sentido, mas o dissemina. Mantém ou restitui as ambiguidades, as múltiplas valências de sentido e de direção (faláramos, inclusive, de memórias multidirecionais). Ela abre, dá espaço, deixa impregnar-se pelo texto e, a partir dele, tece outras imagens. Permite que as memórias do autor se comuniquem com as do leitor, tenta criar espaços porosos para esse encontro. Não é antecipatória, ou busca não ser, embora os cegos estendam suas mãos para descortinar o véu da noite. É reparadora, também, por recuperar, restaurar e reparar seu objeto (aí no sentido psicanalítico mesmo), por tentar devolver algo à obra que esta mesma entregou em puro dom (sua voz, seus silêncios, sua potência expressiva, sua vitalidade...) e permitir alguma reintegração e transformação (do leitor inclusive). Essa leitura (ou interpretação) reconhece, usufrui e restabelece a alteridade

\footnotetext{
${ }^{46}$ Deixaremos em suspensão e oscilação essa denominação. Não sabemos onde termina Auster e onde começa "A." e a procissão de inúmeros personagens. Ficção e realidade se embaralham, história e literatura são porosas, principalmente no primeiro livro de Paul Auster, que comentaremos mais que os outros, de modo a usá-lo como um trampolim ou moldura para encontrarmos os demais.
} 
da obra, mesmo tendo se deixado contaminar tanto por ela. Do encontro fertilizante, algo de novo pode surgir.

Figueiredo cita Dewey nesse sentido:

O material que de que se compõe a obra de arte pertence ao mundo comum, não ao eu, mas há expressão pessoal na arte porque o eu assimila este material de um modo singular, repondo-o no mundo público em uma forma que constrói um novo objeto. (1934 apud Figueiredo, 2014, p. 74)).

Essa leitura reparadora, por se deixar envolver também no plano dos afetos, comunicar-se afetivamente com a obra, muitas vezes dando margem a sentimentos e sensações difíceis (estranhamento, desorientação, clausura... para citar alguns que emergiram nessa leitura em especial), parece tentar devolver algo em gratidão ao atravessar os lutos silenciosos (talvez porque, em alguma medida, trabalho de luto tenha sido favorecido).

Podemos reler tanto a nossa trajetória quanto a de Auster e seus personagens, a partir das três leituras que realizamos, como ilustrando o atravessamento dessa difícil oscilação entre essas posições (poder-se-ia ousar dizer suplementares): a desorientação que leva à paranoia, o movimento reparador que reconstitui e revitaliza.

Auster parece ter vivenciado todo esse complexo de desorientação, cegueira e tentativa de reconstituição e restituição do self quando de seu enfrentamento da morte do pai, lutando por encontrar em sua memória algo que pudesse lhe dar algum acesso ao ser espectral que era seu pai.

As duas fotos do álbum de família que ele escolhe para ilustrar o livro A invenção da solidão, para servir de fragmentos de ruínas - já um traço do traço - a partir dos quais reconstruir a história de seu pai e a suai, portam essa dimensão do mistério, do estranhamento, da cegueira e da escuridão.

Paul Auster responde ao chamado invisível desse pai, que não o olha de frente, ou o olha de maneira desfocada, obliquamente. Um dos olhares vem do pequeno Sam Auster, ainda bebê, no colo de sua mãe, talvez ainda lutando para coordenar o foco de sua visão, talvez mirando um futuro incerto em busca de seu futuro filho (se supusermos, loucamente e a título de exercício da imaginação poética, que podemos reencontrar o adulto no seu olhar quando criança numa foto, talvez nos mirando também). No meio da imagem, da foto que fora rasgada e colada, os dedos do avô, agarrando-se à imagem para tentar voltar do mundo dos mortos para o dos vivos. Estranho aprofundamento de dimensões, de camadas ancestrais e “fotogeológicas”. 
É um sonho talvez comum a muitos a ideia de se projetar numa imagem (numa foto, quadro, filme etc) para poder habitar a cena e viver as possíveis estórias que tais imagens poderiam contar, como retratado pelo filme Dreams, de Akira Kurosawa, num de seus sonhos em que entra no universo dos quadros de Van Gogh. O movimento inverso também é sonhado, como no filme A rosa púrpura do Cairo, de Woody Allen, em que o personagem salta da tela do cinema. No caso da foto da família Auster, contudo, de maneira mais sinistra, os dedos irrompem das profundezas invisíveis da foto e da história da família, tentando assombrar e espectralizar ainda mais o que já é espectral. Os dedos perfuram a foto e atravessam camadas ontológicas e temporais, sacudindo o lento processo de sedimentação da memória. Os dedos do avô funcionam como "pontos da memória”, segundo Hirsh (2012), ou como "punctum", segundo Barthes (1981): pontos que furam, perfuram, ferem, aferroam e apontam. Interpelante e que leva a interpelar, em reversibilidade, o punctum, para Barthes, pode ser um detalhe, um objeto parcial, mas que atrai, instiga, incide em minha percepção, convocando para maior atenção, visão ou leitura. No entanto, o punctum é também ponto cego, que não se deixa ver totalmente, que esconde talvez outras cenas. E não sou eu quem busca o punctum, é ele que salta da imagem, desequilibrando o que o studium organiza e aplaina num nivelamento de interesse.

Citemos Barthes para contrastar, rapidamente, suas duas modalidades de olhar a fotografia:

\begin{abstract}
Muitas fotos, infelizmente, permanecem inertes diante do meu olhar. Mas mesmo entre as que têm alguma existência a meus olhos, a maioria provoca em mim apenas interesse geral e, se assim posso dizer, polido: nelas, nenhum punctum: agradam-me ou desagradam-me sem me pungir: estão investidas somente do studium. O studium é o campo muito vasto do desejo indolente, do interesse diversificado, do gosto inconsequente: gosto/não gosto, I like/ I don't. O studium é da ordem do to like, e não do to love; mobiliza um meio desejo, um meio querer; é a mesma espécie de interesse vago, uniforme, irresponsável, que temos por pessoas, espetáculos, roupas, livros que consideramos “distintos"” (Barthes, 1981, p. 33, itálicos no original).
\end{abstract}

O studium não desperta esse pungente interesse do punctum, pois ele é da ordem do investimento geral, mas sem "acuidade particular" (ibid., p. 31), uma flutuação do olhar que pode se encantar pelo quadro geral da imagem, mas para logo em seguida a relegar ao olvido, condição bem conhecida dos nossos contemporâneos usuários de internet. 
O segundo elemento vem quebrar (ou escandir) o studium. Dessa vez, não sou eu quem vou buscá-lo (como invisto com minha consciência soberana o campo do studium), é ele que parte da cena, como uma flecha, e vem me transpassar. Em latim existe uma palavra para designar essa ferida, essa picada, essa marca feita por instrumento pontudo; essa palavra me serviria em especial na medida em que remete também à ideia de pontuação e em que as fotos são, de fato, como que pontuadas, às vezes até mesmo mosqueadas, com esses pontos sensíveis; essas marcas, essas feridas, são precisamente pontos. Esse segundo elemento que vem contrair o studium chamarei então punctum; pois punctum é também a picada, pequeno buraco, pequena mancha, pequeno corte - e também lance de dados. O punctum de uma foto é esse acaso que, nela, me punge (mas também me mortifica, me fere). (ibid., p. 31, itálicos no original).

Ferida, mortificação, acaso.

No entanto, antes de retomar o punctum, esbocemos, lancemos os dados de duas tradições quase míticas de se lidar com a história, a temporalidade e os eventos para poder então pensar a fotografia Uma primeira tradição, heraclitiana, entenderia o tempo e a história como um rio, transcurso irreversível e linear que a fotografia viria fatiar, interromper e congelar, fraturando-o. A partir dessa concepção, a fotografia, de maneira ilusória, deteria o fluxo do tempo, que, na verdade, sempre seguiria seu curso. Fatiaria um momento de um processo que, em sua essência, seria contínuo, tal como a noção de duração dá a entender. Uma outra concepção, oposta a esta, com origem em Demócrito, veria o tempo e os eventos, ao contrário, como pura emergência de choques de átomos ao acaso, no vazio. O tempo e mesmo a realidade, aqui, seriam, ao contrário, constituídos de explosões, irrupções e pontuações, intercalados pelo vazio. A fotografia, vista sob esse prisma, não poderia prever o desenrolar do tempo histórico nem retomar o que veio antes; nada para além ou aquém de si mesma. Não se trata, portanto, do congelamento em um enquadramento, de uma temporalidade que, de outro modo, fluiria adiante. Antes, diz respeito ao choque, à colisão de diferentes forças para produzir essa espécie de suspensão entre dois nadas. A foto, então, já seria descontextualizadora em si mesma, rompendo com o contexto temporal e histórico, ainda que ela possa ilustrar uma época, uma cena etc. A continuidade do tempo histórico, para essa perspectiva, afigurar-se-ia como um mito, uma ilusão. Vilém Flusser (2000) articularia essas duas modalidades, chegando inclusive a pensá-las como compondo duas modalidades de humor. A de Heráclito seria dramática, a de Demócrito, absurda, já que o acaso é que governaria e qualquer coisa poderia seguir a qualquer outra. Para Flusser, num parentesco com Walter Benjamin, a fotografia inauguraria uma outra época, mas reintroduzindo essa ontologia de Demócrito. 
Para Ulrich Baer (2002), que retoma essas ideias de Flusser e de Walter Benjamim, a câmera seria capaz não tanto de interromper o tempo, mas sim de registrar as fraturas do mundo e do olhar soberano, revelando muitos detalhes e dimensões que são desconhecidos para o olhar cotidiano, incapaz de registrar e integrar aspectos que, embora vividos em algum grau, nem sempre são plenamente assimilados e acomodados, deixando muitos restos na sombra. A ideia de inconsciente ótico guarda parentesco com isso ${ }^{47}$.

Baer apostaria, então, num parentesco entre a fotografia e aquilo que também descontextualiza, aquilo que incide como uma cena chocante ou com uma intensidade tal, além de certo limiar, que leva alguém a passar por algo, mas sem conseguir assimilá-lo : o trauma. Baer vê a memória traumática como tendo a mesma estrutura ${ }^{48}$ da impressão fotográfica, e é o que leva muitos estudiosos do tema em neurobiologia (mas mesmo em psicanálise) a empregar a metáfora (talvez um tanto literal até) de uma impressão traumática que é registrada fotograficamente, mas sem a integração em outros tipos de memória “semântica” (Besel A.van der Kolk; Onno van der Hart, 1995), que permitiriam sua estocagem, recuperação e narração. A memória traumática não é esquecida, já que ela segue circuitos externos à memória convencional. Para trazermos Derrida de volta, é um foradentro.

Charlote Delbo (1985), sobrevivente de Auschwitz falaria de memória profunda, em contraste com a memória ordinária. Essa memória profunda, encapsulada, mas com força e dinamismo próprios - e sempre involuntária -, rasgaria a pele da memória ordinária, irrompendo e trazendo à tona as cenas impossíveis de serem esquecidas (pois não entram no circuito do esquecimento e da rememoração).

A psicanalista Juliet Mitchell (2000), no entanto, entende que essas memórias traumáticas não são de fato memórias, mas algo mais próximo às percepções, e seu retorno, uma espécie de alucinação perceptiva, isto é, traços de experiência que retornam, mas não como memória. Eles produzem esse caráter de imediaticidade, o que não significaria realidade, ou então seria uma outra compreensão de realidade, como na concepção lacaniana de um Real que rasga o tecido (sempre amarrado pelo Simbólico) da realidade. Nos termos de Mitchell, seriam “apresentações,” e não representações. Assim como Caruth (1994), Mitchell

\footnotetext{
${ }^{47}$ Poderíamos arriscar que, no nosso caso, nas fotos de Auster, e em todas as literaturas que inserem as fotografias em suas narrativas, algo de um inconsciente ótico-literário se desenha.

${ }^{48}$ Trata-se de uma estrutura traumática e não somente de um evento isolado. Essa concepção é tributária de Cath Caruth (1996), a partir de sua releitura de Freud. O trauma só pode ser apreendido a posteriori, envolveria mais de um tempo. Seu sentido viria somente depois do evento que causa a efração, e a história (sempre traumática em alguma medida) seria a retomada e a religação desses tempos.
} 
crê que essas percepções desafiam a compreensão. Ou talvez, e é Caruth que insinua isso, também podem ser o transbordamento da compreensão pelo seu excesso, porque viu demais.

Ora, voltando ao punctum, se a fotografia comportaria, em sua estrutura mesma, essa homologia com a memória traumática, o punctum intensificaria isso ao extremo.

No caso de Paul Auster, nosso autor é perfurado pelas fotos. A foto da família, com o pai ainda pequeno, pontua e aponta para um além ou aquém (mas inapreensíveis à primeira vista), e o que ela grita dos escombros é uma dor que nunca fora ouvida diretamente por Auster, mas somente entreouvida por intermédio do silêncio do pai. Esse pai, como sua fotomontagem insinua, com cinco versões de si mesmo ao redor de uma mesa, mas sem cruzar os olhares, em faces petrificadas quem sabe, demonstra essa outra dimensão de uma dor que não pode aparecer. Aqui, o fantasma não se insinua pelos dedos sem corpo, como “órgãos sem corpo”, como a imagem sugerida pela releitura que Zizek fez de Deleuze (Zizek, 2011), mas sim pela multiplicação de imagens, que talvez sejam as guardiãs de um defunto, as sentinelas que guardam o avô de Paul Auster e seu segredo, bem como o próprio Sam Auster.

As criptas, como anunciávamos em passos fantasmáticos desde o início, são forjadas a partir da transmissão de segredos, em silêncios, em trans-(o)-missões. Destina-se algo ao futuro, às outas gerações, mas sem respeitar ou mesmo sendo avesso à transmissão tradicional das narrativas, cuja ausência ou decadência na Modernidade Walter Benjamin enlutava. Destina-se, em missão e em segredo, uma verdade que não pode ser revelada. Esse enigma, contudo, como o punctum, perfura e assombra, interpelando e, ao mesmo tempo, repelindo (as sentinelas anunciam algo e o protegem).

Os pais retornam, fazem suas reaparições na forma de fantasmas, como em Hamlet. O fantasma do pai de Auster, já em vida, desenhara sua origem de muitas formas, a partir de diferentes versões da morte do seu próprio pai, avô de Paul Auster, mas versões todas incompatíveis umas com as outras, todas sentadas à mesa, mas nenhuma se olhando. Em nossa leitura, a fotomontagem do pai de Auster na mesa de fato funciona como uma "sessão espírita”, na metáfora utilizada por Paul Auster, mas que ele não leva adiante. Sam Auster está invocando a si mesmo, mas também, entendemos, a seu pai, avô de Auster, e em segredo. A cripta, então, torna-se lugar de velamento e, paradoxalmente, de invocação.

Auster participa dessa cena teatral de invocação. É sensível à invocação que seu pai, talvez a partir de toda sua vida de segredos e de cegueira, parecia silenciosamente convidar o filho a participar. Multiplicação das invocações. O pai, em segredo, sem o filho saber, talvez sempre convocara o filho - pelo rastro de ausência que deixava (embora ele tenha deixado fotos e pistas do paradeiro do desastre) - a participar dessa exumação dos corpos-fantasmas. 
Na cena da fotomontagem, então, temos a sobreposição de tempos e interpelações, com funções de convocação, testemunho, proteção e resgate. Uma foto serve de antecâmara para adentrar na outra, mergulhando num passado de ausências. Religação de gerações, de múltiplos fantasmas. E os fantasmas surgem e se multiplicam sempre que existem segredos, conforme Schwab (2010), retomando o casal Nicolas Abraham e Maria Torok, entendia a formação das criptas.

Mas ao sair à caça dos baús e arquivos, inclusive os de sua memória, Auster não encontrará nada que sirva de uma memória válida emocionalmente para conhecer o pai. Os únicos rastros, como dissemos, são essas duas fotos-relíquias, objetos-testemunhos que são portadores de segredos, atuando como punctum, e, ao lado desses objetos interpelantes, outros tantos objetos pessoais, só que esvaziados, formando pilhas de escombros, ou uma cortina de entulhos. "Evidências espectrais”, para usar o termo de Ulrich Baer (). Dessa ausência de mais vestígios, mas interpelado pelas fotos, Auster precisará inventar suas memórias e, em certa medida, as de seu pai. Precisará recriar a solidão do pai e o buraco negro da paternidade - em bricolagem com memórias imaginadas e coladas aos vestígios de ruínas. Precisará dar rosto ao seu pai, como a si mesmo, já que a multiplicação das imagens do pai é o signo invertido do apagamento da subjetividade, a impossibilidade de um self distinto (Cf. Porter, 2011). Auster sente até os ossos esse vazio e essa nostalgia de si mesmo, em ressonância e sinistra afiliação com o buraco negro que é o pai. Ele sente a impossibilidade da tarefa de compreendê-lo, mesmo após ter descortinado o tiro que atravessou seu avô e emudeceu internamente o pai, congelando sua face, tornando-a uma poker face.

Essa ambiguidade do punctum, interpelante e ponto cego, descortinador e encobridor ao mesmo tempo, num mesmo corte incisivo, essa ambiguidade enseja nossos dois movimentos apresentados no início: de um lado, a inquietude e o impulso paranoico (que se transfigura em leitura paranoica também) de sair ao encalço dos rastros e pistas, encontrando e garantindo algum sentido por meio de religação de uma série de fatos desconexos ${ }^{49}$; de outro, a possibilidade de abrir espaço para uma leitura que seja reparadora, não por algum gesto de boa-vontade por parte do autor (e leitor), mas por exigência de vida e vitalidade, pela

\footnotetext{
${ }^{49}$ No capítulo anterior, víamos como Sidney Orr utilizava seu caderno de estórias ora como uma narrativa profética - antecipando-se magicamente aos eventos -, ora como uma retrospectiva (talvez inconsciente, nunca se sabe) de sua vida. O caderno, contudo, tendia a encavalar e misturar esses tempos e espaços, criando uma espécie de emaranhamento quântico-literário, para brincarmos com a descrição que o famoso físico, que adorava gatos, Erwin Schrödinger, descrevia a propriedade básica dos sistemas quânticos (Cf. Gleiser, 2014). A sobreposição e o emaranhamento de tempos, para nosso personagem, além de outros eventos traumáticos, supúnhamos, levava -o a querer exorcizar a incerteza e ambiguidade por meio do seu caderno, mas caderno que também era fonte de disseminação das mesmas ambiguidades e flutuações de sentido, seu phármakon diabólico.
} 
urgência de ressubjetivação e pela esperança de se superar o ressentimento via alguma gratidão.

Para inaugurar os caminhos da memória emocional inexistente, Auster terá que inventar e ficcionalizar a si mesmo, para, então, invocar o Outro: invenção como invocação e invenire (in-venire: o acontecimento do que vem, do que chega). Invenção, é fácil notar, já anuncia essa esfera de ficção, de fingimento e, nessa linha, de mentira. A ficção em Auster nasce aí, e a Invenção da Solidão marca a estreia do autor no campo da ficção, mesmo que estando, no início, com um pé nela e um pé no autobiográfico. Todavia, a outra face de Janus dessa invenção é que ela é também descoberta, conforme nos conta Junqueira Filho sobre a etimologia dessa palavra:

O latim invenire pressupunha tudo aquilo que podia ser "inventado" ou "encontrado" como se o universo já existisse, pronto para ser desvelado ou para que a divindade [o criador como demiurgo] pudesse tropeçar nele. É o que está implícito no célebre aforismo de Picasso: "Eu não procuro, eu encontro". (Junqueira Filho, 2013, p. 164).

O que nosso autor descobrir será uma invenção, e o que ele inventar, terá vindo do Outro, dessa invocação endereçada a Auster pelos fantasmas e que ele endereça a eles também. Auster portará a palavra desse Outro, mesmo que sejam palavras inventadas, e geralmente roubadas, tomadas aqui e ali para compor seu livro de memórias de cego.

Auster seria o porta-voz cego de outro cego que é também um emudecido, e enxertemos aqui as palavras de Noemi Jaffe (2012) para nos servir de porta-voz:

O porta-voz é o guardador da voz. Ele ouve a voz que outra pessoa não emitiu, pega, guarda no bolso e porta, como uma carteira ou uma chave. Daí, ele, portador da voz, transmite para os outros as coisas que não estão dentro daquela voz guardada. (...) O porta-voz é um ladrão da pior espécie. (...) O porta-voz porta o que de mais preciso alguém pode ter. Por que o dono da voz autoriza o porta-voz a portar suas palavras? Por que ele não fala? $\mathrm{O}$ dono da voz não fala porque: não consegue, não tem habilidade, não tem tempo, não lembra, não administra, não domina, não articula. Concede a outro a licença de articular suas ideias e opiniões. Vá, fique com elas. Mas quais são, dono da voz? Não sei, confio em você. Invente-as. (Jaffe, 2012, p.163)

O trabalho de luto que se inicia, logo nas primeiras fotografias que Auster nos apresenta, é marcado pela invenção, pelo furto, pela culpa, pela hospitalidade ao Outro, pela invocação... 
Se Auster descobre e relata - como se fosse um constatativo - a cena do crime que petrificou o pai, que não tinha para si o escudo de Perseu para lhe desviar do olhar direto da Medusa, contudo suas preces invocadoras são uma espécie de performativo, uma prece cega, em ato, no vazio, dirigida a um Outro inapreensível.

As emanações das fotos, transmitindo as primeiras criptas (e as fotos são os primeiros túmulos que encontramos nos livros de Auster), incitam Auster a narrar seus silêncios e desvãos. As imagens dão espaço às palavras. A narrativa segue à imagem, nessa espécie de comentário e emolduramento feito de palavras. Um tecido de palavras - uma bandagem - para estancar o sangue que escorre do avô para o pai, e aí se coagula e vira pedra, e que, ao cair em Auster, vira mancha e sombra. Auster revive isso nos escritos, e essa sombra alcançará muitos personagens, que sempre estão no rastro de algum desaparecido.

Viver com a sombra dos antepassados é uma condição universal do ser humano, quer habitemos no difícil intervalo da quebra da tradição, quer estejamos abraçados e envolvidos por uma segura rede de proteção narrativa e simbólica. Entretanto, há diferentes níveis de sombreamento, e a sombra se torna mais pesada ou mais leve conforme as disparidades e desproporções desarranjarem a passagem e a transmissão dos legados transgeracionais.

Durban (2011) retoma, como já havíamos feito antes, a ideia de “quimera” para pensar as heranças transgeracionais. Ele discrimina entre viver com a sombra, viver sob a sombra e ser a sombra. Viver com a sombra dos legados familiares é uma condição universal, como dissemos. Habitamos a história - mais ou menos silenciosa - de nossos antepassados e de nossa cultura. Eric Hobsbawm dizia que vivemos mergulhados até o pescoço na História, somos de cabo a rabo marcados e encharcados por ela (Cf. Bauman, 2013).

Se estamos mergulhados nessa rede transubjetiva, isso não impede a possibilidade de um relativo afastamento e diferenciação que abra caminho para os processos de individuação. Tolerar viver com o passado e seus legados mais ou menos traumáticos implica em conseguir contê-los relativamente dentro de si, o que por sua vez exige uma superfície continente que possa envelopar a subjetividade. Por outro lado, quando essa diferenciação torna-se complicada, a sombra se faz pesar mais, oprimindo o self e sua capacidade de adquirir mente própria, self que vive sob esse legado. A sombra, nesse caso, persegue, reclama e solicita, exigindo que os descendentes canalizem e sirvam de condutores, como vasos abertos, sem fundo, o peso do material do passado. Por fim, ser a sombra significa perder a total capacidade de discriminação, sendo tomado pelos vultos do passado, que se aderem ao rosto e o desfiguram. As quimeras psíquicas, para Durban, surgiriam dessa invasão e possessão do sujeito. Por desarticularem as funções psíquicas mais essenciais, como, por exemplo, a de 
delimitação (dentro/fora, eu/não-eu, consciente/inconsciente, presente/passado etc), entre outras coisas, o próprio corpo torna-se alvo e palco das lutas e resistências do sujeito, que sofre com o naufrágio de sua vida subjetiva. Pode-se dizer, conforme Figueiredo ${ }^{50}$ lê Jean Améry, que o traumático sempre vai se inserir nessa fronteira - mesmo que móvel - entre o somático e o psíquico. Améry indica isso no título de um de seus ensaios, contidos no livro Além do crime e castigo: tentativas de superação ${ }^{51}$, sobre sua experiência mortífera com os nazistas. Nas fronteiras da mente, ou do espírito, é onde o terror incidirá, e muitas vezes o corpo servirá de alojamento tanto para o que restar dos estilhaços da violência quanto para as ruínas da subjetividade.

A passagem pela cultura e seus objetos, pela memória de terceiros e outras estórias, por outros pais e filhos, fará Auster começar a reconstituir seu rosto, sua face que não encontra espelho no próprio pai, mas somente em outros. A saída para a escrita, inclusive a escrita e narração das fotos que resistem a ser exploradas, balizará sua trajetória. Narra-se as fotos e faz-se literatura com elas. No livro, várias outras fotos, agora escritas, costuradas no corpo do texto, comentadas, porém não reveladas, ou reveladas por meio das palavras, vão sendo redesenhadas (como reescrevemos e redesenhamos os livros de Auster). Outros retratos servirão de modelo para seu autorretrato. Essa ekphrasis proporcionará algum descongelamento, já em regime de trabalho de luto.

Escrever as imagens realiza algo a mais nessas cenas de luto: essa escrita desfaz a objetificação da imagem congelada e, portanto, a transpõe do campo da stasis, da imobilidade e da mortificação - o que Barthes chama "morte achatada" - para o da fluidez, do movimento e, assim, finalmente, da vida. (Hirsch, 1997, p. 4).

A escrita de Auster, narrando suas fotos e as costurando em seu texto-pele, vai tecendo sua história como filho e como pai a partir de fios invisíveis. A presença da cultura no texto, ajudando a remendar e dar corpo a esse Arlequim que quer chamar a atenção de um pai ausente, é quimérica em si mesma, por usar retalhos simbólicos para compor sua unidade heteróclita. A nossa escrita, por sua vez, numa espécie de (des)costura onírica, também remenda e tenta vestir esse herança, esse corpo (o corpo da obra) que o autor nos deixa, mas também não quer nos deixar nus, despidos. A cena mítica da nudez, nos limiares da inocência,

\footnotetext{
${ }^{50}$ Em disciplina oferecida no segundo semestre de 2013, no curso de pós-graduação em psicologia, na PUC-SP, cujo tema foi "trabalhos psíquicos: as elaborações na clínica e na cultura".

${ }^{51}$ A tradução do título do ensaio em questão, na versão em inglês, foi "At the mind's limits", que também acabou por dar nome ao livro. No Brasil, adotou-se "Nas fronteiras do espírito", e o título do livro foi Além do crime e castigo: tentativas de superação.
} 
que reconduz até Noé, que é surpreendido pelo filho que o vê nu, está nos bastidores desses lances de desvelamento. A condenação e a culpa por ter visto o pai nu, em Auster, diz desse encontro com um pai-criança que viu mais do que poderia ver: viu a face da morte, em sua nudez negra. David Zimmer e Hector Mann também são testemunhas, cada um, desse encontro, lutando um, Zimmer, para superar a perda, e outro, Mann, para se redimir da culpa atroz penitenciando-se com o sepultamento da arte (e não a arte servindo como ação de elaboração e reparação). Os últimos filmes de Hector Mann, produzidos por ele mesmo, deveriam ser vistos por David Zimmer, mas para logo depois serem queimados, reverberando a imagem do livro queimado na tradição judaica (Cf. Ouaknin, 1986).

Em outros textos, na memória dos outros, de Mallarmé e seu filho febril, Anatole, ou de Rembrandt e seu filho, Titus, ou em Jonas, na barriga da baleia, tentando fugir do chamado do Pai, ou de Pinóquio, na barriga do tubarão (e é um tubarão asmático), tentando salvar seu pai, Gepeto, vemos Auster reencontrar objetos da cultura que lhe servem de habitação, como verdadeiros objetos transformacionais, que, com linguagem expressiva própria, permitem que o personagem-autor elabore e se desloque da condição congelada de uma identificação com o vazio.

É interessante notar que, ao escolher esses autores, Auster apresenta uma transferência também multidirecional. Por um lado, identifica-se com os pais, com Rembrandt e Mallarmé, que desenham, narram, temem por e sepultam os filhos. Por outro, em sua repetitiva e aflitiva busca de afiliação, torna-se o filho que se vê abandonado (o que sempre anuncia alguma morte). A partir desse abandono, desse desamparo, dessa posição passiva, e projetando o pior nisso, reaproxima-se da condição de filho, e de seu filho, e teme na enfermidade de Daniel (uma que lhe dificultara a respiração) o risco de perder sua obra mais valiosa, em abandono total e irreversível. A reversibilidade de perspectivas e de posições, religando e atravessando gerações, cria uma cena de resgate mútuo: filho e pai abraçam-se um ao outro para serem salvos, mas ao filho cabendo, em Auster, o peso maior dessa empreitada (o filho carrega a história do pai e, posteriormente, como veremos logo adiante, as catástrofes da História). Nesse resgate, Auster é salvo pelo filho, e consegue se tornar pai (e talvez, pela primeira vez, postumamente, consegue se tornar filho do seu próprio pai, Sam).

A cultura, no quarto fechado de Auster, com sua biblioteca pessoal, arquivo mortovivo, lhe serve como fonte de algum renascimento e de uma ressubjetivação possível, ainda que esse quarto (útero e túmulo ao mesmo tempo) arrisca a se tornar cripta a cada vez que ele reentra nele. Como vimos na Noite do oráculo, a cena de Nick Bowen enterrado e preso no bunker - sua cripta - remete à tentativa de sepultar os mortos-vivos que vagam e atravessam 
paredes e livros ${ }^{52}$, funeral tardio que, por uma temporalidade estranha, talvez só chegue depois do luto (haveria mais de um funeral para uma morte? Seria essa uma outra imagem para a melancolia?).

Porém, também é nesse quarto que Auster reencontrará todos os outros, seus semelhantes, esvaziando, em alguma medida, a sua solidão, como lemos a seguir:

O que ele experimentou, talvez, durante aqueles poucos momentos na véspera de Natal em 1979, sentado sozinho em seu quarto na rua Varick, foi isto: a súbita consciência de que mesmo sozinho, na mais profunda solidão do seu quarto, ele não estava sozinho, ou, para ser mais exato, que no momento em que começou a falar sobre essa solidão ele se tornou mais do que ele mesmo. A memória, portanto, não apenas como a ressurreição do passado particular de alguém, mas como imersão no passado dos outros, o que vale dizer: história - da qual a pessoa tanto participa quanto é uma testemunha, é uma parte e se mantém à parte. (Auster, 1982, p. 156; itálicos meus).

A cultura fornece os traços (trait) que permitirão a Auster compor o retrato (portrait) do seu pai e o seu próprio autorretrato (autoportrait), para jogarmos com os mesmos termos que Derrida (op.cit.) usa em seu livro sobre memórias de cegos. Cultura como religação, como disparador para rearticular e religar o solo intersubjetivo deteriorado (inclusive entre pai e filho). Nesse sentido, mesmo o humor entra em jogo para cumprir esse reencanto, num disparo de vida e riso, numa reinstauração de uma comunidade perdida, ou conflagrada (cf. Miller, 2011). Hector Mann, o desaparecido de O livro das ilusões, preso aos seus filmes mudos e a um passado que o martiriza, ainda assim sai da tela e toca David Zimmer (e lembremos que “zimmer”, em alemão, significa quarto) com suas graças.

O cultura e seus múltiplos representantes, os livros, os cadernos, as pinturas e a tela de cinema, todos textos-tecidos que servem para inscrição, leitura, mediação e projeção, atuam como screen memories, lembranças encobridoras. Cumprem, por um lado, a função de velar e reprimir memórias e, por outro, atuam como tela de projeção para elaborar conteúdos difíceis e indigestos, daí seu caráter ao mesmo tempo defensivo e terapêutico. Fica-se cego a si mesmo para poder reencontrar-se no outro, e, nessa religação, nessa transposição, reencontrar a cultura e a ligação com a humanidade, restabelecendo a confiança em tais laços.

Auster e seus personagens desamparados, sempre fugindo de algo ou em perseguição de alguém (e fuga e busca como sendo uma o anverso da outra), sofrem de uma espécie de

\footnotetext{
${ }^{52}$ A sensação de repetição, de se ter a impressão de ler a mesma estória novamente, em Auster traduz uma dimensão de compulsão à repetição, que em si mesma já é enclausurante. Auster sepulta personagens o tempo todo, e os personagens sempre portam alguma semelhança ou traço de personagens anteriores (nomes, traços físicos, personalidades, a mesma busca pelos desaparecidos etc).
} 
complexo de Telâmaco. Esperam, como Telêmaco, seu pai quase desconhecido, nunca visto, ou cedo perdido, e na idade adulta, ou em sua passagem, saem em sua busca. Ao contrário de Telêmaco, contudo, temos dúvida se Auster reencontra seu Ulisses. Parece-nos, antes, já numa incorporação e sobreposição de mitos, que Auster descortina essa (in)condição da eterna busca de algo ou de alguém (um pai ou uma terra prometida), mas sem garantias de sucesso, um caminhar no deserto ou cruzando mares, mas sem destino ou retorno assegurados. ”Destinerrância” (destinerrance), segundo Derrida (Cf. Miller, 2009), que vem em nosso auxílio (nosso Mentor? ${ }^{53}$ ).

“A”. - façamos essa transcrição, novamente, para nos alertar do recorrente risco de psicanalisarmos o autor - precisa refundar seus mitos pessoais para, quem sabe, escapar da força dos mesmos, para escapar da moira que pode aprisioná-lo, enlaçá-lo em alguma Roda da Fortuna. É verdade, contudo, que os personagens parecem estar, de alguma forma, enredados nessa circularidade enlouquecedora, o que, na nossa leitura, corresponde ao circuito fechado da compulsão à repetição. Uma insistência monótona. As ascensões são provisórias, as quedas, constantes. Algumas vezes, contudo, as quedas ocorrem até mesmo antes de qualquer ascensão. Quedas que não vieram depois de nenhuma altura atingida, o que colocaria alguns personagens de Auster numa patamar aquém da tragédia (Cf. Eagleton, 2013). Seja como for, a monotonia sussurra um aprisionamento muito mais vasto, sem limites visíveis no horizonte.

É Blanchot que nos conta dessa aparência de monotonia de escritores obsessivos, como se estivessem circulando ao redor da uma fonte de luz, queimando-se e voltando novamente a ela. Uma obsessão que parece até precedê-los, sendo convocada a partir de outro lugar, obrigando a um trabalho infindável:

A solidão do escritor, essa condição que é o seu risco, proviria então do que pertence, na obra, ao que está sempre antes da obra. Por ele, a obra chega, é a firmeza do começo, mas ele próprio pertence a um tempo em que reina a indecisão do recomeço. A obsessão que o vincula a um tema privilegiado, que o obriga a redizer o que já disse, por vezes com o poder de um talento enriquecido mas outras vezes com a prolixidade de um redito extraordinariamente empobrecedor, sempre com menos força, sempre com mais monotonia, ilustra essa necessidade em que aparentemente se encontra de retornar ao mesmo ponto, de voltar a passar pelos mesmos caminhos, de preservar no recomeço do que para ele jamais começa, de pertencer à sombra dos acontecimentos, não à sua realidade, à imagem, não ao objeto, ao que faz com que as próprias palavras possam tornar-se imagens, aparências - e não signos, valores, poder de verdade. (Blanchot, 1955, p. 15).

\footnotetext{
${ }^{53}$ Mentor, uma das divindades a proteger Telêmaco, o acompanhava e o orientava no cultivo da prudência e da nobreza. (Cf. Jaeger, 1986).
} 
Essa insistência compulsiva e hesitante, que pode ser reencontrada inclusive em Freud, nos começos falsos e recomeços de seu livro sobre Moisés, transmite a incidência do traumático em sua dimensão mais formal (Kaplan, 2005), deixando à mostra as cicatrizes do texto sob a forma de interrupções ${ }^{54}$.

Essa repetição, retornando reiteradamente a um vazio descentrado, também comunica as dificuldades e as vicissitudes do trauma e sua perlaboração, A melancolia sempre espreita, pois o luto pelas perdas parece nunca concluído, ou sempre está incerto de suas conquistas.

Contudo, nessa religação com a cultura e a História, a qual é permeada de violência e catástrofes (11 de setembro, Dachau e o Holocausto, Camboja etc), um movimento parece ser posto em marcha, articulando essas progressões traumáticas, para usarmos a gramática ferencziana, à própria possibilidade da História e de sua elaboração, o que também está perto da tese freudiana, em sua ficção histórica, em relação à invenção do povo judeu.

Uma temporalidade complexa e nada linear (como é também a temporalidade psicanalítica), feita de múltiplas camadas e de entrelaçamentos, de sobreposição de dores, paixões e lágrimas, marcará o entrecruzamento de uma dimensão vertical - a herança e o sofrimento dos ancestrais que lhe vêm à cabeça, feito gárgula que despenca - com a horizontalidade da religação com seus próximos e seu cotidiano. Esse cruzamento de tradição e contemporaneidade, mas também de lágrimas e de dores, formando um caderno-arquivo com múltiplas camadas (um palimpsesto) dos sofrimentos que atravessam a História, parece ser uma das heranças que recebemos de Auster, numa espécie de patrimônio criptografado e úmido, quase como se fosse uma cruz cristã que esse judeu ateu carrega: quimera teológica.

Auster não é um filho de sobreviventes do Holocausto, sendo que seu testemunho desse desastre é indireto, como sua herança dos fatos (o personagem Ed Victory havia acusado sutilmente Nick Bowen de que ele conhecera Dachau apenas por fotos, como se fosse por atrás de um vidro blindado). Contudo, ele precisa reinventar também essas memórias inexistentes. Criar, novamente como nos mostra Hirsch (2012), suas “pós-memórias”.

Em grande medida, nessa encruzilhada de gerações, povos, segredos e lágrimas, a ausência deixada pelo pai tatua uma matriz de dor que conversará e comercializará com outras dores. Nathaniel Hawthorne (além de nomes como Ralph Emerson, Henry David Thoreau, Franz Kafka e Samuel Beckett) é uma influência marcante nas primeiras obras de Auster.

\footnotetext{
${ }^{54}$ Freud estava às voltas com a iminência da Segunda Guerra, com o exílio forçado e a perda de seu solo de ancoragem histórico, Viena, além de atravessar um doloroso conflito - pelo menos assim o lê Yerushalmi (1991), Caruth(1996) e Kaplan (2005) - com sua identidade judaica.
} 
Hawthorne lhe infundiu, entre outras experimentações literárias, essa ideia de um personagem que abandona a vida para assistir, a distância, os outros se desesperarem e irem atrás dele (Cf. Varvogli, 2001) . Ora, mas será que foi Hawthorne mesmo? Ou somente ele? Ou será que foi Sam Auster, seu pai, o desparecido-mor, o autor dessa farsa? Será que foi Sam, inclusive, que “inventou” discretamente Hawthorne para Paul Auster? Ou será que é Auster que reinventa Hawthorne? Indecisão quanto à origem dos produtos literários. Isso não deixa de ser uma artimanha de Auster, ao jogar com o nivelamento e a equiparação entre todos os autores envolvidos na transmissão das estórias, tornando todos comentadores uns dos outros.

No entanto, a ausência de si mesmo - que Auster mimetiza de Sam, ou recebe dele como uma injunção -, saindo também do mundo (como se para verificar como seria o mundo sem ele), é a própria condição do surgimento da fantasia, uma condição de possibilidade que se assenta na própria invisibilidade. Como nos ensinara a psicanálise, a criança excluída da cena primária (ou então excluída do contato com o seio materno) também produz aí o universo da fantasia, ou dá os primeiros passos para produzir memória e pensamento.

Contudo, Auster, na segunda parte de Invenção da solidão, o seu “Livro da Memória”, no qual adota a terceira pessoa, não apenas luta desesperadamente para salvar Gepeto, quer dizer, seu pai, como também se debate para se eriçar do pântano viscoso chamado melancolia. Para isso, com dissemos atrás, precisa fazer se reencontrar três gerações de crianças: Sam, Paul e Daniel.

Porém, o curioso, e isso é recorrente nos três textos que escolhemos, é que são as figuras femininas que também auxiliam nessa travessia de resgate dos desaparecidos: Anne Frank, Alma e Grace, figuras da generosidade feminina (que, no nosso autor, sempre se aproxima dos perigos da ilusão e idealização) . Em Homero, conforme nos mostra Jaeger (op.cit), os conselheiros de Telêmaco estão disfarçados de homens, mas na verdade seriam deusas que, generosamente, acompanham, instruem e velam pela transformação do menino em herói. Selecionamos essa imagem de deusas veladas para ressaltar, novamente, a multiplicação dos encobrimentos e recobrimentos.

No quarto de Anne Frank, Auster chora pela menina que fora esmagada em sua inocência, mas também pelo seu pai. Em Noite do oráculo, Sidney Orr chora pela criança de Dachau, mas chora por seu filho que não nasceu, e chora por todas as crianças assassinadas que se reúnem na figura do bebê natimorto da prostituta que se droga com crack. O texto e as narrativas, como lembranças e histórias encobridoras, vão substituindo uns aos outros, numa permutação que se espraia até se tornar indefinida. De onde vem ou onde se inicia o choro? 
A indefinição das fronteiras, que são borradas, deslizadas e apagadas, também aparece na temporalidade elástica de Noite do oráculo, em que as consequências surgem antes das causas, ou pelo menos se confundem com elas, num tempo fora dos eixo ( "out of joint”, diria Hamlet, e também Derrida, em uma das várias traduções possíveis), profético e cheio de reversões.

Um certo ramo da tradição judaica comparece aí. Citemos Yerushalmi para ilustrar essa temporalidade elástica, que se contrai e se estende, feito um "acordeão”:

Diferentemente dos escritores bíblicos, os rabinos parecem brincar com o Tempo como se este fosse um acordeão, expandindo e retraindo à sua vontade. Onde a especificidade histórica é uma marca registrada nas narrativas bíblicas, aqui o agudo senso bíblico de tempo e lugar é muitas vezes substituído por um aparente anacronismo inconsciente e desenfreado. No mundo da agadá, Adão pode instruir seu filho Seth na Torá, Shem e Eber podem fundar uma casa de estudos, os patriarcas podem instituir os três serviços diários da liturgia judaica normativa, Og, Rei de Basham, está presente à circuncisão de Isaac e Noé profetiza a tradução da Bíblia para o grego. É claro que há algo bastante atraente neste vasto segmento do universo rabínico no qual as barreiras comuns do tempo podem ser ignoradas e todas as épocas podem ser colocadas em diálogo fluente uma com a outra. (Yerushalmi, 1982, p. 37).

Alargamento ou concentração cósmica do tempo histórico, em que, num ponto, (punctum) podem comparecem todos os tempos, todos os outros e toda humanidade.

Citemos Auster agora, fazendo chocar e reverberar imagens próximas, como se fossem comentários de comentários:

Tudo, portanto, está presente ao mesmo tempo em seu pensamento, como se cada elemento refletisse a luz de todos os demais e ao mesmo tempo emitisse seu inextinguível fulgor próprio e singular. Se existe alguma razão para ele estar em seu quarto agora, é porque há dentro dele alguma coisa ávida para ver tudo de uma só vez, saborear esse caos em toda sua simultaneidade bruta e premente. E no entanto a narração disso é necessariamente lenta, a tarefa sutil de tentar lembrar o que já foi lembrado. A caneta nunca será capaz de se mover depressa o bastante para pôr no papel todas as palavras descobertas no espaço da memória. Algumas coisas se perderam para sempre, outras talvez serão de novo lembradas, e outras ainda foram perdidas, encontradas e perdidas outra vez. Não há como ter certeza de nada disso. (Auster, 1982, p.156).

E eis que as distinções também correm o risco de se perderem, gerando uma sombra extensa de indefinição e incerteza. Ora, a situação traumática, noção a que o Freud tardio chegara para falar dessa indefinição entre dentro e fora (de onde surge o traumático?), nos 
parece mais um capítulo desse livro de comentários de comentários, e parece traduzir bem a dimensão do traumático que permeia a obra de Auster. Esta obra, além disso, é inundada com cenas de culpa e de movimentos de reparações, de descobertas criativas, destruições e recriações (os personagens rasgam os livros e os cadernos, queimam os filmes, enterram arquivos que nunca se tornaram obra porque nunca chegaram a ser contra-assinados, testemunhados, por alguém, tal como entende Derrida a constituição de uma obra). Sidney Orr rasga o caderno por medo de ter ficado preso nele, mas também por culpa do que ele poderia ter produzido. Hector Mann manda queimar os filmes que não foram vistos por quase ninguém, em penitência pelos crimes ancestrais. A. precisa rasgar as velhas e vazias memórias que tinha de seu pai para inventar outras.

Todavia, se há um Livro da Memória em Auster, há também um extenso Livro das Lágrimas, mas que o encontramos, contudo, em nossa tese, que nunca passou de uma constelação de hipóteses, abaixo da teoria e das proposições, e suas visões soberanas. Hipóteses nebulosas, confusas, cegas...

Nossa escrita pareceu realizar com Auster o que o mesmo realizara com o seu pai, e que também nos é relatado em outro livro de cegos, o de Derrida, que, por sua vez, reconta, entre outras, a estória bíblica de Tobias devolvendo a vista ao pai.

Derrida, na exposição que guiou no Louvre a partir de gravuras escolhidas por ele, comenta que um dos desenhos, atribuído a Rembrandt, fora originalmente interpretado e recebido, em 1803, como se fosse um desenho retratando uma cena cirúrgica. ${ }^{55}$ No desenho, que também tem outra versão em pintura do mesmo Rembrandt, estão o anjo Rafael, Tobite, Tobias e sua mãe.

Eis a descrição de Derrida:

Rafael aparece à beira do desenho de Rembrandt, vela a operação, mas está no centro de um Tobite Recuperando a Vista atribuído a Rembrandt. A sua singularidade não reside porém apenas aí. O esboço permanece bastante indeterminado. Tobias e a mãe afadigam-se estranhamente por detrás do velho cego; nas suas costas, a cena das mãos, manobra ou manipulação, evoca uma operação propriamente cirúrgica, não ouso, ainda não, dizer gráfica. Tobias parece segurar um instrumento estiliforme, uma espécie de marcador para gravar ou de escalpelo. (Derrida, 1991, p. 34).

A cena desenha o milagre da retomada da vista pelo pai. O filho lhe devolve a visão, guiado pelo anjo, e porta um instrumento pouco claro, um stilu (estilo enquanto um

\footnotetext{
${ }^{55}$ Derrida a cita a dúvida e indecisão registrada junto com o envio do desenho para o Louvre: “Cirurgião fazendo o penso a um ferido pintado a bistre sobre papel branco? Rembrandt" (Derrida, 1991, p. 33)
} 
instrumento perfurante), que pode ser um instrumento cirúrgico ou gráfico. Ou então um instrumento cirúrgico que realiza sua obra pela grafia, permitindo que um retraçar seja também um curar.

Cena de reconciliação pela grafia inspirada, em que aquele que era cego, mas que guardara a esperança do retorno do filho para ser salvo, desfaz-se em lágrimas.

Insistamos um pouco mais, citando mais extensamente outra passagem...

Luz velada, lágrimas e véus, amortalhamento dos corpos e dos olhos: antes de perguntarmos o que são ou o que fazem as lágrimas, haveria que seguir a composição enredada destes motivos num Livro [o de Tobite] que foi primeiramente tido por apócrifo. O filho é a luz, o olho suplementar ou excessivo do pai, o guia do cego, o seu próprio bordão, mas também o da mãe em lágrimas que incessantemente o lembra. Primeiro, a seguir à partida de Tobias: “Ana, sua mãe, pôs-se a chorar, dizendo a Tobite: 'Por que foi que mandaste o meu filho? Ele era o arrimo da nossa velhice; era ele que ia e vinha para nós”". Tobite responde-lhe. "[...] 'hás-de vê-lo com os teus olhos [...] um anjo bom acompanhá-lo-á.’ [...] Ela, então, deixou de chorar”. Raquel, Edna e Sara choram abundantemente aos descobrirem que Tobias é o filho de Tobite e que este perdeu a vista. Mais tarde, enquanto Tobias ainda não voltou, Ana chora ainda: "Não há dúvida de que o meu filho morreu [...] Infeliz de mim, filho, que te deixei partir, tu, que eras a luz dos meus olhos!”. Aquando da cura, também Tobite se desfaz em lágrimas, e aquilo que ele vê em primeiro lugar é o seu filho. Dá graças não apenas por ver, de ver por ver, mas por ver o filho. Chora de reconhecimento, não tanto por finalmente ver, mas porque o filho lhe devolve [rend] a vista ao tornar-se [en se rendent] visível: ele devolve-lhe [lui rend] a vista ao tornar-se [se rendre] visível e para se tornar [se rendre] visível, ele, o seu filho, ou seja, a luz dada como luz recebida, emprestada, devolvida, permutada. Filho quer dizer: os olhos, ambos os olhos... (ibid., p. 35; itálicos no original)

Cena de reversibilidade da salvação e da gratidão entre pai e filho. Mas se insistimos tanto na leitura dessa filiação fraturada foi para fazê-la cruzar com outras cenas de trauma, luto, melancolia e reparação, criando uma espécie de matriz solidária e sensível a (impregnável por) outros sofrimentos.

O Pinóquio de Auster, em nossa versão, o boneco de madeira lutando para não ser mais uma marionete, uma escultura móvel que ainda não adquirira certidão de autoria e subjetividade, sentado sobre uma pedra, olhando para baixo com os braços encostados em suas pernas, esse Pinóquio deixa cair suas lágrimas no chão e o que vê na poça, numa imagem confusa e fragmentada, talvez num sonho, não é somente, ou fundamentalmente, sua imagem em reflexo narcísico. Os personagens de Auster, vivendo situações catastróficas e carecendo de espelhos vivos, aventuram-se para encontrar testemunhas - muitos duplos, inclusive -, mas o risco de submersão é grande, e os desvios e ciladas aprisionantes disseminam-se aos moldes 
da repetição traumática. Para além de um espelho vazio ou de um duplo tão evasivo ou imobilizado quanto ele, que lhe devolveria apenas uma integridade rígida, Pinóquio, nessa poça de lágrimas, aprofunda-se (mergulha) sobre si mesmo e, simultaneamente, vê todos os outros que ele sonhou, convocou, inventou e também chorou para poder se tornar menino de verdade e se subjetivar.

Esse Pinóquio que aprende andar com dificuldade, carregará seu Gepeto a nado, mas também ensaiará saltos e voos para levar Dédalo em suas costas, se transformando em Ícaro (e nosso texto também foi realizando a transição de mitos e imagens sonhadas, no transporte permitido pela metáfora).

A noção de decolagem, como retomada por Anzieu (1981), a partir de um personagem de Proust, faz sua visita novamente aqui. A decolagem, rumo ao Outro e à transcendência que for possível, se dá enfrentando os lutos e perdas no meio do caminho. E a “de-colagem”, o descolamento de um passado imantado pela perda e pelo vazio - ou mesmo pelo catastrófico -, faz uso da criatividade e de identificações heroicas que sustentam ou convocam de "cima", do alto, os personagens que arriscam seus voos, mesmo que inventando seu itinerário pelos céus. Dizia André Comte-Sponville, retomando Marx: "trata-se de viver e lutar: lançar-se ao assalto ao céu, como dizia Marx, mesmo que esse céu não exista”. (Comte-Sponville, 1988, p. 9, itálicos no original).

No planetário ${ }^{56}$ literário de Auster, sonha-se em reconstituir um céu de estrelas, uma constelação de imagens e pontos no horizonte que ajudem os sobreviventes a se guiarem (e voltarem a sonhar) novamente após os desastres dos séculos.

\footnotetext{
${ }^{56}$ E lembremos, numa louca disseminação sonora e gráfica, que também podemos escutar os rastros do nome Sidney Orr, nosso personagem de Noite do oráculo, em orrery (planetário, em inglês).
} 


\section{Considerações finais}

Retomemos nossa epígrafe da tese: "sempre se perde perdão quando se escreve”, dizia Derrida, em seu texto Circonfissão (Bennigton; Derrida, 1991, p. 41).

Derrida deixa em suspensão os sentidos da sentença, bem como seu referente ou endereçamento. Pelo que se pede perdão quando se escreve? A quem? É uma blasfêmia o ato de escrever? Qual crime se insinua na escrita? Ou do que ela é cúmplice?...

Tais questões assombraram Derrida, principalmente quando se deparava com a literatura (e sua promessa de algum prazer) às voltas com a dor ou a morte do outro. Questão obsedante, insistente, que espreita cada palavra que se profere ou se inscreve nos rastros de acontecimentos traumáticos e catastróficos. Questão que também perturbou Adorno (1962), ao condenar como bárbaro qualquer lirismo poético após Auschwitz.

Nossos personagens perseguiram uma palavra de reconciliação, de invenção e reinvenção de si e dos outros, palavras que pudessem salvaguardar os mortos ao dizê-los, nomeá-los, invocá-los, mesmo que, paradoxalmente, com isso, tais personagens corressem o risco de serem enterrados em livros, cadernos e textos. Personagens-escritores, assombrados pelo que realizam com sua escrita, e que se tornam reféns dela.

Auster cria personagens que saem ao encalço de outros fantasmas. Na busca, eles se deparam com o que não queriam ou esperavam ver, e retornam, cobrando as razões dessas missões em direção ao inferno, que lhes trouxeram um gosto amargo. Acusam, assim, em alguma medida, o escritor, que se vê, em resposta, atormentado por culpa. Contudo, talvez nesse (re)encontro com o traumático, orquestrado pelo escritor, encenado pela primeira vez, ou pela enésima vez, algo se dê: a possibilidade de se viver uma dor perdida, inseri-la e sonhá-la na existência, transformando uma compulsão a repetir numa compulsão a simbolizar.

A escrita de uma ausência (inclusive de uma dor ausente, que deveria estar lá, mas fora perdida, que nunca pode ser sentida plenamente ou chorada) dará um primeiro contorno a um vazio de memória. A ficção, para nosso escritor, surge como desvio para lidar com o desvão, reduplicando o intervalo para que tal buraco pudesse ser contornado por “dentro”. Esse desvio, contudo, torna-se outra forma de tentar se aproximar ainda mais de um pai ausente, criando, tanto pelo desvelamento dos segredos do pai quanto pela ficção de si, uma forma de intimidade nunca experimentada: intimidade póstuma. Escrita de dentro do vazio, que é internalizado, ou incorporado, para retomarmos o vocabulário ferencziano. Contudo, 
esse vazio exigirá compartilhamento (inclusive com o leitor), como se alguma espécie de restauração da intersubjetividade fraturada fosse demandada.

O quarto vazio, metáfora do útero e do claustro, do nascimento (ou renovação) e do aprisionamento, do silêncio sereno e do silêncio ruidoso, nesse quarto de escritor encontraremos os múltiplos destinos do luto e da elaboração. Tais quartos serão o templo para o encontro com a arte que revitaliza (os filmes de cinema-mudo que reavivam David Zimmer), o abrigo para o escritor-eremita traduzir as inúmeras páginas do palimpsesto de dor de muitas gerações, a cápsula narcísica para envelopar as recém-nascidas subjetividades, o túmulo para sepultar os fantasmas ou os mortos-vivos que assombram, o túnel do tempo para religar e atravessar passado, presente e futuro... enfim, nesse quarto multidimensional, tempos, espaços, memórias, vazios, invenções, passado ancestral e arte serão postos em movimento, e se chocarão.

Nessa oscilação, o quarto com sua função continente (ou todos os objetos capazes de acolher a projeção de aspectos fraturados e difíceis, como o livro ou o caderno, em nosso autor) sempre corre o risco, em Auster, de se converter num claustrum, espécie de objeto continente que se enrijeceu e se degradou, perdendo seu potencial de acolhimento e transformação ${ }^{57}$. A dificuldade de se perlaborar os traumas que marcam os personagens - e que rompem, ou pelo menos embaralham, os limites convencionais (entre gerações, entre livros, entre ficção e "realidade”) - aponta para essa tensão entre funções defensivas e regeneradoras. Ao final, a escrita nunca garante uma travessia bem-sucedida, não garante apaziguamento ou reconciliação fácil. Os lutos são incertos.

Às vicissitudes da perlaboração soma-se o risco do fracasso de se redimir os mortos, como também a emergência do fracasso como um imperativo ético. "É preciso velar pelo sentido ausente”, diria Maurice Blanchot (1983, p. 42). A liberdade inaudita da literatura, que pode, em tese, tudo dizer, sofre uma reviravolta nessa tradição de escritores que lidam com as catástrofes (individuais e coletivas). A literatura perde sua inocência. E muitos personagens de Auster padecem da culpa do sobrevivente ${ }^{58}$.

Além disso, em nosso autor, a extensão da catástrofe é indeterminada, outra pista para referendar a ideia de que as origens dos traumas (no plano coletivo e individual) são sempre incertas. Temos, então, a contaminação de dores, o deslocamento de lágrimas que, por meio de vasos comunicantes literários, desaguam em outras margens. Portanto, a concepção tardia

\footnotetext{
${ }^{57}$ Para essa concepção do claustro como a versão patológica de um continente vivo, ver Willoughby (2001).

${ }^{58}$ Para uma reconstituição histórica do desenvolvimento da síndrome do sobrevivente, ver Leys (2007).
} 
freudiana de uma situação traumática ajusta-se melhor a essa indefinição das bordas do traumatismo.

Se a série regressiva é indeterminada, se lutos e traumas atuais sempre ressuscitarão outros lutos pregressos, numa cadeia pouco mapeável, e reacendendo um desamparo talvez estrutural, o mesmo vale para a progressão em relação ao futuro: nunca se está certo se um trauma foi suficientemente elaborado, deixando sempre restos não metabolizáveis que exigirão renovadas elaborações. Um estranho e paradoxal movimento surge daí: se, por um lado, o trauma e o luto silenciam (e exigem silêncio), por outro, eles disparam uma série infinda de narrações e tentativas de elaboração.

Se os soldados que retornavam da Primeira Guerra (fato notado por Walter Benjamin) eram indivíduos emudecidos, testemunhas de uma interrupção indizível, todavia eles incitaram uma fúria narrativa para tentar dizer o inominável. A literatura e os estudos do trauma foram e são recorrentemente insuflados e disseminados após tais desastres coletivos, como se, embora dizer fosse perigoso (já que ele reativa os terrores de outrora), ainda assim tal dizer nunca é insuficiente, sempre exige mais.

Em Auster, os livros, a escrita, a literatura e a cultura de maneira geral, como modalidades de testemunho, suportam esses dizeres impossíveis, que religam gerações e catástrofes, o que não é isento de conflito e culpa. Mesmo assim, ainda que as obras sejam rasgadas ou queimadas (ou talvez por isso mesmo também), volta-se a elas recorrentemente como suporte de ligação. Enquanto objetos transformacionais, os livros viabilizam difíceis travessias, oferecendo um "meio de transporte” e uma matriz possível para se enfrentar tais passagens rumo ao incerto, como o caixão que permite a Ismael, em Moby Dick, sobreviver ao naufrágio.

Mas também nós tememos por nossa sobrevivência, e os labirintos de Auster tanto nos atraíram quanto nos enredaram. Se identificações heroicas são necessárias para se alçar voo e partir do labirinto - sair do livro -, talvez também tenhamos recorrido a elas:

Alguns anos atrás, o autor da presente tese sonhara com Jacques Derrida (um dos seus guias pelos labirintos de cegos). No sonho, ambos se encontravam num ônibus que fazia um translado para algum avião (quem alçaria voo?). Ainda em sonho, L.H. chora pela morte do filósofo, que estava, contudo, com ele no ônibus. O filósofo em resposta, por sua vez, assegura ao sonhador que ele (quem?) ficará bem.

O sonho termina em suspenso, como um cartão-postal recebido, mas sem remetente. Seu endereçamento também é desconhecido. Como na literatura, sua origem e destinatário são secretos, embora suspeitemos de alguma relação velada com tudo isso. Nada é certo. Seja 
como for, com esse sonho, recebido e retransmitindo, deixamos o Livro. Ao fundo, ouvimos as palavras do poeta Andrew Marvell ${ }^{59}$, em relação a Milton: “(...) Esses olhos que choram, aquelas lágrimas que enxergam.”

${ }^{59}$ Cf. Caputo, 1997 


\section{REFERÊNCIAS}

Abraham, N.; Torok, M. (1987). A casca e o núcleo. São Paulo: Escuta. 1995.

Adorno, T. (1974). Notas de literatura I. São Paulo: Duas Cidades; Ed. 34, 2003.

Anzieu, D. (1981). El cuerpo de la obra: ensayos psicoanalíticos sobre el trabajo creador. Méxo e Argentina: Siglo Veintiuno Editores.

Améry, J. (1977). Além do crime e castigo: tentativas de superação. Rio de Janeiro: Contraponto. 2013.

Auster, P. (1982). A invenção da solidão. São Paulo: Cia das Letras, 2004. (1985). Trilogia de Nova York. São Paulo: Cia das Letras, 2004. . (1992). A arte da fome. Rio de Janeiro: José Olympio, 1996. . (2002). O livro das ilusões. São Paulo: Cia das Letras. . (2003). Noite do oráculo. São Paulo: Cia das Letras, 2004 (2012). Sunset Park. São Paulo: Cia das Letras, 2013.

Badiou, A. (2013). Elogio ao amor. São Paulo: Martins editora.

Baer, U. (2002). Spectral Evidence: the photography of trauma. Cambridge, Massachusetts; London, England: The MIT Press. 2005.

Barthes, R. (1980). Câmara clara: nota sobre a fotografia. Rio de Janeiro: Nova Fronteira.

Bauman, Z. (1999). Modernidade e Holocausto. São Paulo: Zahar. . (2013). Tempos líquidos. São Paulo: Zahar.

Bessel A. van der Kolk; Onno van der Hart. The intrusive past: the flexibility of memory and the engraving of trauma. In: Caruth, C (Org.) Trauma: exploration in memory. Baltimore and London: John Hopkins University Press, 1995.

Bennington, G. \& Derrida, J. (1996). Jacques Derrida. São Paulo: Jorge Zahar Editora.

Bergson, H. (1924). O riso - ensaio sobre a significação da comicidade. São Paulo: Martins Fontes.

Bilton, A. (2011). In the kingdom of shadow: Paul Auster, The book of illusions and Silent Film. In S. Ciocia, \& J. González (Orgs.). The invention of illusions: international perspectives on Paul Auster. Cambridge Scholars Publishing. 2011.

Blanchot, M. (1955). O espaço literário. São Paulo: Rocco. 2011. 
. (1983). La escritura del desastre. Caracas: Monte Avila Editores. 1990.

Blanchot, M.; Derrida, J. (2000). The instant of my death/ Demeure: fiction and testimony. Stanford, Califórina: 2000.

Boulter, J. (2011). Melancholy and the archive: trauma, history and memory in the contemporary novel. London: Bloomsbury Academic.

Caputo, J. (1997). The Prayer and Tears of Jacques Derrida: Religion without Religion. Bloomington, Indiana: Indiana University Press.

Caruth, C. (1996). Unclaimed experience: trauma, narrative, and history. Baltimore: The Johns Hopkins University Press.

Comte-Sponville, A. (1988). Viver. São Paulo: Martins Fontes. 2000.

Delbo, C. (1985). Days and memory. Illinois: The Malboro Press/Nothwestern. 2001

Derrida, J. (1972). A farmácia de Platão. São Paulo: Iluminuras. 2005.

(1991). Memórias de cego: o auto-retrato e outras ruínas. Lisboa: Fundação Calouste Gulbenkian. 2010

. (1988) The ear of other: Otobiography, Transference, Translation. Christie McDonald (ed.). Lincoln: U of Nebraska P.

. (1992). Acts of literature. New York: Routledge.

. (1993). Espectros de Marx. Rio de Janeiro: Relume-Dumará.

. (1997). Adeus a Emmanuel Lévinas. São Paulo: Perspectiva.

. (1999). Dar la muerte. Espanha: Paidos, 2000.

. (2001). Mal de arquivo: uma impressão freudiana. Rio de Janeiro: Relume-Dumará.

Press.

(2001a) The work of mourning. Chicago and London: The University of Chicago . (2003). Anne Dufourmantelle convida Jacques Derrida a falar da

Hospitalidade. Trad. Antonio Romane. São Paulo : Escuta.

Durban, J. Shadows, ghosts and chimaeras: On some early modes of handling psycho-genetic heritage. International Journal of Psychoanalysis. 92: 903-924, 2011.

Eagleton, T. (2003). Sweet violence: the idea of the tragic. Oxford: Blackwell Publishing. . (2013). How to read literature. New Haven and London: Yale University Press. 
Figueiredo, L.C. (2003). Psicanálise: Elementos para a clínica contemporânea. São Paulo: Escuta. . (2014). Cuidado, saúde e cultura - trabalhos psíquicos e criatividade na situação analisante.. São Paulo: Escuta.

Feyerabend, P. (1975). Contra o método. São Paulo: Unesp. 2003.

Giddens, A. (1999). Modernidade e identidade. Rio de Janeiro: Jorge Zahar Ed. 2002.

Gumbrecht, H. U. (2012). Graciosidade e estagnação - ensaios escolhidos. Rio de Janeiro: Contraponto Editora.

Hirsch, M. (1997). Family frames: photography narrative and postmemory. Cambridge, Massachusetts, and London, England: Harvard University Press.

Hirsch, M. (2012). The generation of postmemory: writing and visual culture after the Holocaust. New York: Columbia University Press.

Jaeger, W. (1986). Paideia: a formação do homem grego. São Paulo: Martins Fontes. 2013.

Jameson, F. (1991). Pós-modernismo: a lógica cultural do capitalismo tardio. São Paulo: Ática. 1997.

Junqueira Filho, L.C.U. Entre a criação e a invenção: a busca pela forma em Georges Steiner, Wilfred Bion e Rem Koolhaas. Ide. São Paulo 36 [56]. 2013.

Kaplan, E. (2005). Trauma culture: the politics of terror and loss in media and literature. New Brunswick, New Jersey, and London: Rutgers University Press.

LaCapra, D. (2001). Writing history, writing trauma. Baltimore: The Johns Hopkins University Press.

Lévinas, E. (1961). Totalidade e infinito. Coimbra: Edições setenta.

Leys, R. (2007). From guilty to shame: Auschwitz and after. Princeton and Oxford: Princeton University Press. . (2013). History, literature, critical theory. Ithaca e London: Cornell University Press.

Luckhurst, R. (2008). The trauma question. New York: Routledge.

Miller, J. H. (2009). For Derrida. New York: Fordham University Press. . (2011). The conflagration of community: fiction before and after Auschwitz. Chicago: University of Chicago Press.

Mitchell, J. (2000). Mad men and medusas: reclaiming hysteria. New York: Basic Books.

Morrison, T. (1987). Amada. São Paulo: Cia. das Letras, 2011. 
Ouaknin, M. (1986). The burnt book: reading the Talmud. Princeton, New Jersey: Princeton University Press. 1995.

Phillips, A. (2001). Houdini's box: the art of escape. New York: Vintage Books.

Pirandello, L. (1921). Seis personagens à procura de autor. São Paulo: Ed. Peixoto Neto. 2004.

Porter, R. (2011). Bureau of missing persons: writing the secret lives of fathers. New York: Cornell University Press.

Roussillon, R. (2013). Manuel des meditations thérapeutiques. Paris: Dunod.

Schneider, M. (1997). A proximidade em Lévinas e o Nebenmensch freudiano. Cadernos de Subjetividade. 1997, 5, 7-90.

Schwab, G. (2010). Haunting legacies: violent histories and transgenerational trauma. New York: Columbia University Press.

Selligman-Silva, M. (2005) O local da diferença. São Paulo: Ed.34.

Varvogli, A. (2001). The world that is the book: Paul Auster's fiction. Liverpool: Liverpool University Press.

Yerushalmi, Y.H. (1982). Zakhor: história judaica e memória judaica. São Paulo: Imago. 1992. 1992.

(1991). O Moisés de Freud: judaísmo terminável e interminável. São Paulo: Imago.

Willoughby, R.T. (2001). 'The dungeon of thyself': the claustrum as pathological container. International Journal of Psychoanalysis. (82). 917.

Zamora, J. (2004). Th. W. Adorno: pensar contra a barbárie. São Leopoldo: Nova Harmonia.

Zizek, S. (2011). Órgãos sem corpos - Gilles Deleuze. São Paulo: Companhia de Freud. 
